\title{
TECHNICALLY RECOVERABLE DEVONIAN SHALE GAS IN OHIO
}

\author{
July 1983 \\ Work Performed Under Contract No.: AC21-82MC-19239 \\ By \\ Vello A. Kuushraa and Donald E. Wicks \\ Lewin and Associates, Inc. \\ U. S. Department of Energy \\ Office of Fossil Energy \\ Morgantown Energy Technology Center \\ P.O. Box 880 \\ Morgantown, West Virginia 26505 \\ 1090 Vermont Ave., N.W., Suite 700 \\ Washington, D.C. 20005 \\ Walter K. Sawyer \\ Mathematical and Computer Services, Inc. \\ Patrick R. Esposito, Ph.D., P.E. \\ Engineering Decision Consultants, Inc.
}




\section{DISCLAIMER}

This report was prepared as an account of work sponsored by an agency of the United States Government. Neither the United States Government nor any agency Thereof, nor any of their employees, makes any warranty, express or implied, or assumes any legal liability or responsibility for the accuracy, completeness, or usefulness of any information, apparatus, product, or process disclosed, or represents that its use would not infringe privately owned rights. Reference herein to any specific commercial product, process, or service by trade name, trademark, manufacturer, or otherwise does not necessarily constitute or imply its endorsement, recommendation, or favoring by the United States Government or any agency thereof. The views and opinions of authors expressed herein do not necessarily state or reflect those of the United States Government or any agency thereof. 


\section{DISCLAIMER}

Portions of this document may be illegible in electronic image products. Images are produced from the best available original document. 
PREFACE

This report is a technical integration effort to estimate the technically recoverable gas resource of the Devonian Shale formation in Ohio. Results are based on the integration of the most recent data and research that evolved in the Eastern Gas Shales Subprogram which makes up a significant part of DOE's Research in Unconventional Gas Recovery Program. Specifically the information used in this study includes: (1) a compilation of the latest geologic and reservoir data for the gas in place; (2) analys is of the key production mechanisms; and (3) examination of alternative stimulation and production strategies for most efficiently recovering this gas.

The general approach taken in this study builds on the existing knowledge gained in the last six years and, in particular, from several important summary type documents recently concluded under the sponsorship of DOE/METC. These documents include:

- Mound Lab Report -- geochemistry of the Appalachian Basin

- Cliffs Minerals Report - natural fracture systems in the Appalachian Basin

- DOE's offset well report - reservoir properties in Ohio

In addition, gas production and open flow data that became available as public information from the recent upsurge of drilling in the Appalachian Basin are used to supplement the primary sources.

The objective of this study is to integrate all of the known information into a useful summary document covering broad regions. It is an attempt to synthesize acquired data on a high enough level to help industry in their decision making process on where to drill and how to extract for shale gas once the market and gas price warrant new ventures. It should be noted that no attempt was made to quantify the risks and uncertainities associated with shale well drilling ventures. This analys is is the responsibility of the investor/producer group. Accordingly, this report was prepared as a good reference document from which to work.

Project Mana gement

Eastern Gas Shales 


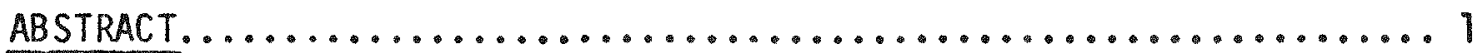

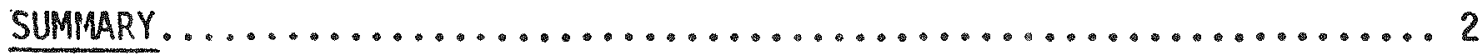

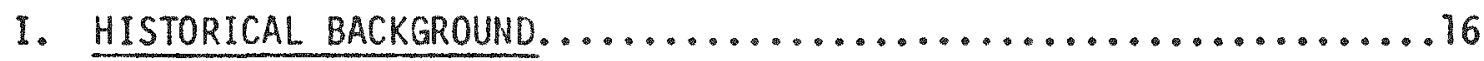

II. STUDY PURPOSE, APPROACH, AND METHODOLOGY...............

A. KEY TECHNICAL QUESTIONS.......................18

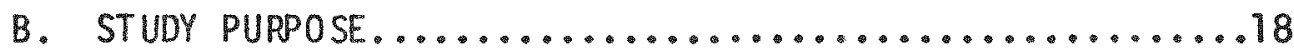

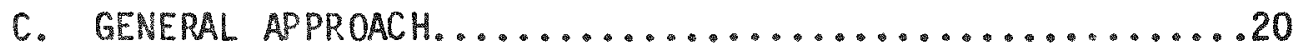

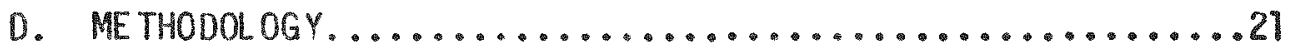

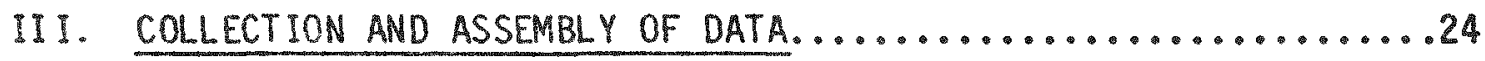

A. IDENTIFICATION OF GEOLOGIC/RESERVOIR DATA.........24

1. Parameters Required.........................24

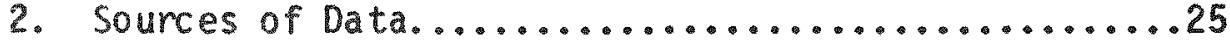

B. DEVELOPMENT OF REPRESENTATIVE DATA BY COUNTY.........30

1. Constant Reservoir Characteristics...............30

2. Variable Reservoir Characteristics................34

c. DEVELOPMENT OF REPRESENTATIVE DATA FOR EACH REGION....47

1. Horizontai Stress.........................47

2. Natural Fracture Orientation..................47

3. Pemeability Anisotropy......................50

4. Reservoir Properties by Area..................51

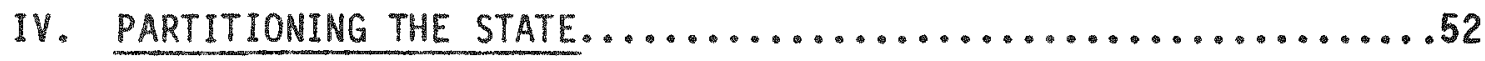

\%. RESERVOIR MODELING AND WELL STIMULATION.................56

A. SUgar MOdel.................................56

B. DELINEATION OF STIMULATION CASES................58

C. MODELING OF STIMULATION CASES................60 
TABLE OF CONTENTS

(continued)

Page

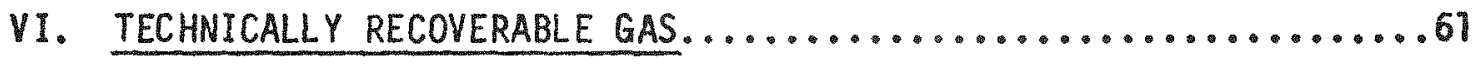

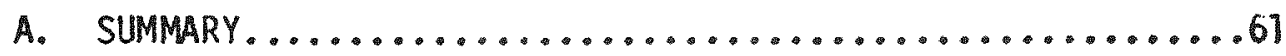

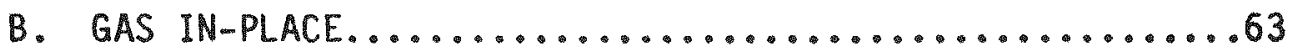

C. DISCUSSION OF RECOVERABLE GAS AND RECOVERY EFFICIENCY..66

D. TECHNICALLY RECOVERABLE GAS, BY WELL..............70

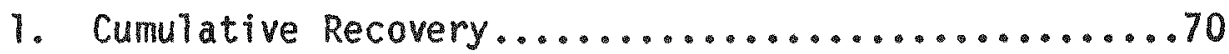

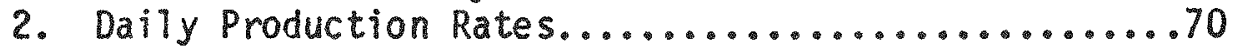

E. DRILLING AREA AND DRILLING POTENTIAL............... 74

F. NEED FOR AND VALUE OF ADVANCED WELL

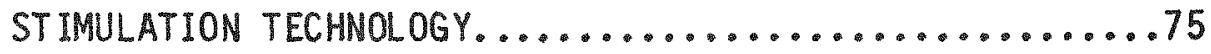

G. REVIEW OF TECHNICALLY RECOVERABLE GAS, BY AREA.......78

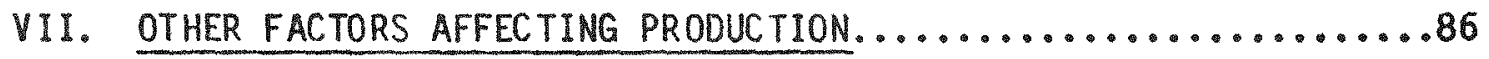

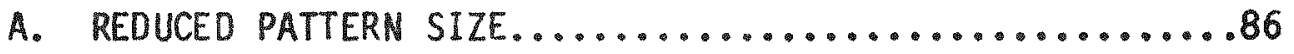

B. ALTERNATIVE INDUCED FRACTURE BEHAV IOR

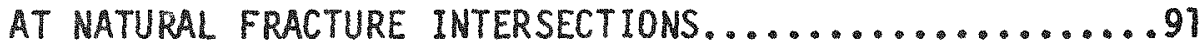

1. Low Fracture Intersection Angle................91

2. High Fracture Intersection Angle................93

3. Induced Fracture Perpendicular to

Natural Fracture..........................94

C. NON-INTERSECTION OF NATURAL FRACTURE SYSTEM.........95

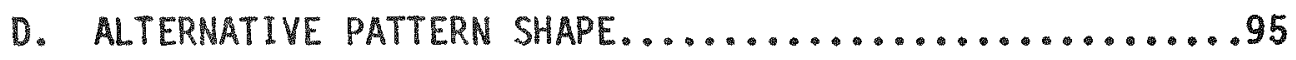

E. CO PRODCUTION WITH OIL PRODUCING SHALES............99

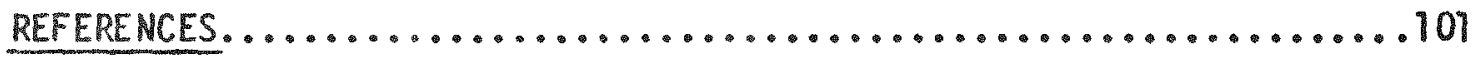

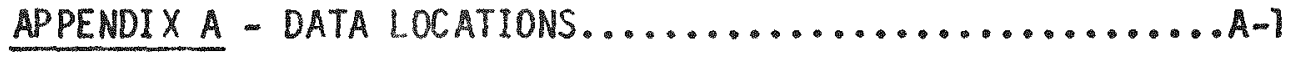

APPENDIX B - EGSP CORE WELL DESCRIPTIONS AND LOCATION.... A-6

APPENDIX C - REPRESENTATIVE WELL SELECTION METHODOLOGY....A-12

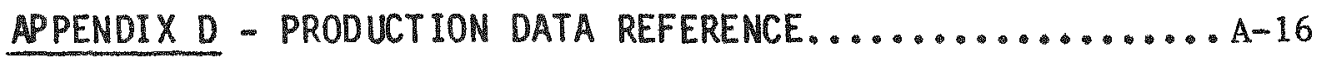




\section{LIST OF EXHIBITS}

Page

EXHIBIT 1 PRIMARY PARTITIONED AREAS, DEVONIAN GAS SHALES OF OHIO/AVERAGE RESERVOIR PROPERTIES BY AREA.........5

EXHIBIT 2 TECHNICALLY RECOVERABLE GAS, BY AREA AND

ST IMULATION. .............................99

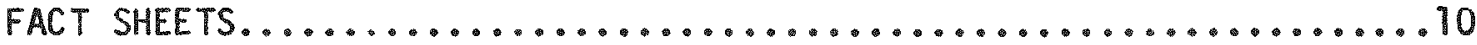

EXHIBIT 3 AVAILABILITY OF PRODUCTION DATA BY COUNTY MAP.......27

EXHIBIT 4 INITIAL OPEN FLOW (24 HOURS) MAP...............33

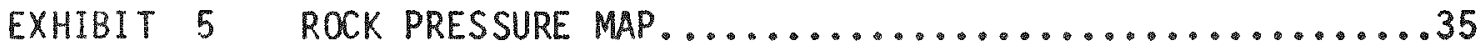

EXHIBIT 6 CALCULATED INDIGENOUS GAS CONTENT MAP.............37

EXHIBIT 7 LOWER AND MIDDLE HURON UNITS GAS CONTENT MAP........38

EXIIBIT 8 NATURAL FRACTURE SPACING MAP.................40

EXHIBIT 9 EFFECT OF PROPPANTS ON CONDUCTIVITY.............42

EXHIBIT 10 HISTORY MATCH - REPRESENTATIVE LAWRENCE COUNTY WELL...44

EXHIBIT 11 HORIZONTAL STRESS TRAJECTORIES MAP.............48

EXHIBIT 12 REGIOHAL ORIENTATIONS NATURAL VS. INDUCED

FRACTURES MAP...........................49

EXHIBIT 13 NATURAL. FRACTURE ORIENTATION MAP..............53

EXHIBIT 14 MECHANICAL FABRIC TREND IN SHALE MAP.............54

EXHIBIT 15 PRIMARY PARTITIONED AREAS, DEVONIAN GAS SHALES

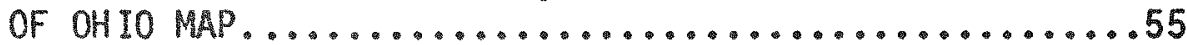

EXHIBIT 16 STIMULATION TREATMENT SCHEMATICS...............59

EXHIBIT 17 CUMULATIVE GAS PRODUCTION TREND MAP.............71

EXHIBIT IS FRACTURE PROPAGATES ALONG NATURAL FRACTURES,

FRACTURE CROSSES NATURAL FRACTURE, AND FRACTURE

ARRESTED AT INTERSECTION WITH NATURAL FRACTURE

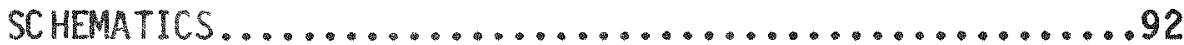

EXHIBIT 19 ILLUSTRATION OF MATRIX SKIN FOR WIDELY SPACED

NATURAL FRACTURES.............................96

EXHIBIT 20 MATRIX SKIN VERSUS PRODUCTION..................97

EXHIBIT 21 DVERALL OIL SOURCE ROCK POTENTIAL................100 


\section{LIST OF TABLES}

Page

TABLE 1

TABLE 2

TABLE 3

TABLE 4

TABLE 5

TABLE 6

TABLE 7

TABLE 8

TABLE 9

TABLE 10

TABLE 11

TABLE 12

TABLE 13

TABLE 14

TABLE 15

TABLE 16

TABLE 17

TABLE 18

TABLE 19

TABLE 20

STRATIGRAPHIC DEVONIAN SHALE UNITS..............29

SUMMARY OF SHALE MATRIX PARAMETERS FROM OHIO

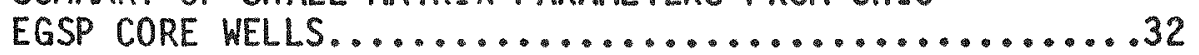

REQUIRED RESERVOIR PARAMETERS...............45

RESERVOIR PROPERTIES FOR OHIO COUNTIES...........46

AVERAGE RESERVOIR PROPERTIES BY AREA............5I

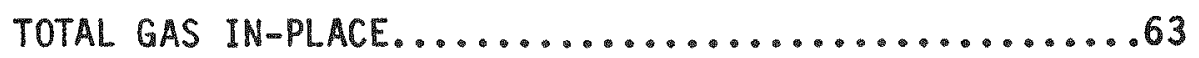

GAS IN-PLACE BY SOURCE, FOR HURON TARGET INTERVAL....65

TECHNICALLY RECOVERABLE GAS BY AREA AND

ST IMULATION METHOD...........................66

RECOVERY EFFICIENCY BY AREA AND STIMULATION METHOD....67

GAS RECOVERY EFFICIENCY BY AREA AND GAS SOURCE.......68

TECHNICALLY RECOVERABLE GAS BY AREA AND GAS SOURCE....69

PER WELL GAS RECOVERY BY AREA AND STIMULATION METHOD..72

PER WELL GAS PRODUCTION RATES BY AREA AND

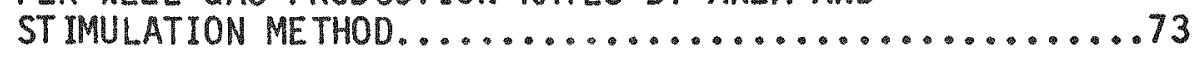

INCREMENTAL GAS PRODUCTION OVER BOREHOLD SHOOTING.....77

CUMULATIVE GAS RECOVERY BY TYPE OF STIMULATION

(AREA I)................................80

AVERAGE DAILY GAS PRODUCTION BY TYPE OF STIMULATION

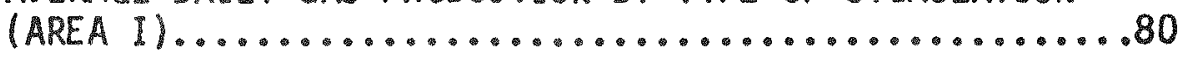

CUMULATIVE GAS RECOVERY BY TYPE OF STIMULATION

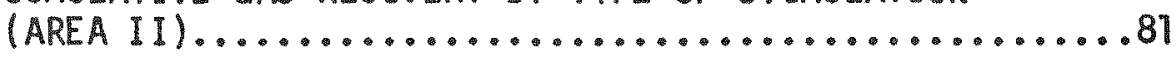

AVERAGE DAILY GAS PRODUCTION BY TYPE OF STIMULATION

(AREA II)....................................81

CUMULATIVE GAS RECOVERY BY TYPE OF STIMULATION

(AREA III)...............................82

AVERAGE DAILY GAS PRODUCTION BY TYPE OF STIMULATION

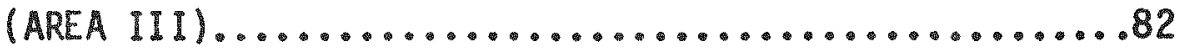




\section{LIST OF TABLES \\ (continued)}

Page

TABLE 21 CUMULATIVE GAS RECOVERY BY TYPE OF STIMULATION

(AREA IV)..............................83

TABLE 22 AVERAGE DAILY GAS PRODUCTION BY TYPE OF STIMULATION

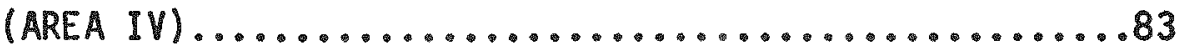

TABLE 23 CUMULATIVE GAS RECOVERY BY TYPE OF STIMULATION (AREA V)..................................84

TABLE 24 AVERAGE DAILY GAS PRODUCTION BY TYPE OF STIMULATION (AREA V)......................................84

TABLE 25 CUMULATIVE GAS RECOVERY BY TYPE OF STIMULATION (AREA VI)................................85

TABLE 26 AVERAGE DAILY GAS PRODUCTION BY TYPE OF STIMULATION (AREA VI).................................85

TABLE 27 SELECTION OF WELL SPACING, AREA I..............88

TABLE 28 SELECTION OF WELL SPACING, AREA II..............89

TABLE 29 SELECTION OF WELL SPACING, AREA III..............89

TABLE 30 SELECTION OF WELL SPACING, AREA IV...............90

TABLE 31 SELECTION OF WELL SPACING, AREA $\vee$ AND VI..........90

TABLE 32 SELECTION OF DRAINAGE PATTERN SHAPE, AREA II........98 
The technically recoverable gas from Devonian shale (Lower and Middle Huron) in ohio is estimated to range from 6.2 to $22.5 \mathrm{Tcf}$, depending on the stimulation method and pattern size selected.

This estimate of recovery is based on the integration of the most recent data and research on the Devonian Age gas-bearing shales of Ohio. This includes: (1) a compilation of the latest geologic and reservoir data for the gas in-place; (2) analysis of the key productive mechanisms; and, (3) examination of alternative stimulation and production strategies for most efficiently recovering this gas.

Reyond a comprehensive assembly of the data and calculation of the technically recoverable gas, the key findings of this report are as follows:

- A substantial volume of gas is technically recoverable, al thougn advanced (1arger scale) stimulation technology will be required to reach economically attractive gas production rates in much of the state;

- Well spacing in certain of the areas can be reduced by half from the traditional 150 to 160 acres per well without severely impairing per-we 11 gas recovery: and,

- Due to the relatively high degree of permeability anisotropy in the Devonian shales, a rectangular, generally 3 by 1 well pattern leads to optimum recovery.

Finally, al though a consistent geological interpretation and model have been constructed for the Lower and Middle Huron intervals of the Chio Devonian shale, this interpretation is founded on limited data currently available, along with numerous technical assumptions that need fur ther werification. 


\section{SUMMARY}

PURPOSE OF THE STUDY. This study integrates past research and current data in developing an estimate of technically recoverable gas resources for the Devonian shales of onio. In so doing. the study has had to grapple with the key (and often difficult) technical issues imbedded in such an analysis, including:

- How to properly characterize and interpret the major production mechanisms that govern the flow of gas in the Devonian shales:

- How to use secondary geologic/reservoir measures to define gas potential areas;

- What types of well stimulation techniques to apply in the various geological settings; and

- How to reliably simulate, through reservoir models, the gas flow rates, and to optimize ultimate gas recovery?

This report builds and improves on the technologic knowledge base to provide a scientific understanding of the Devonian shale gas resource. It's primary audience is intended to be explorationists, geologists, and R\&D managers interested in a detailed basin level anlysis of the resource, along with independent operators interested in choosing a stimulation technique in a given area.

The purpose of this study is to examine these issues in broad regional settings. Therefore, the findings of this study are not intended to be representative of any specific lease area or well location.

METHODOLOGY. The study methodology consisted of eight steps:

1) Identification of Consistent Geologic/Reservoir Data. Several reservoir parameters, such as matrix permeability and porosity, were found not to vary widely and thus were kept 
constant over the study area. The reservoir data and parameters were assembled from:

- Historical gas production and well records,

- The EGSP core well program, and

- The offset Well Test Program (Meigs County, Ohio).

2) Development of Variable Geologic Data By County. Reservoir parameters that showed strong regional variation, such as gas content and pressure, were developed for each county from actual data or were extrapolated from a series of isoline maps developed for ohio. This data was based on:

- Geological and geochemical reports by Cliffs Minerals and Mound Facility:

- Fracture conductivity studies by Terra Tek:

- Stress-ratio maps prepared by U.S. Department of Energy's Morgantown Energy Technology Center; and

- Rock pressure data from 257 wells in 15 counties.

3) Assembly of Actual Gas Production Data. Historical gas production data for ohio were gathered from state and company records, as follows:

- Long-term production data were assembied from 108 wells in 11 counties; and

- Initial open flow (24 hr.) data were collected from 222 wells in 12 counties.

The location and concentration of these data are shown on Exhibit 1. 
4) History Matching of Production Data and Productive Interval. A reservoir simulator entitled Simulator for Uhconventional Gas Recovery (SUGAR) was used to match production data and back-calculate the remaining unknown reservoir parameters of fracture permeability and net productive interval, as well as to ensure consistency in the basic data.

5) Definition of the Fracture Regimes. Beyond the data required for analyzing the performance of well stimulation by borehole shooting, additional geological data were required to properly evaluate well performance with improved stimulation technology. These additional data included:

- Determining directional components of fracture permeability to reflect permeability ani sotropy;

- Identifying the expected angle of intersection between induced and natural fractures to estimate whether the induced fracture will cross or terminate in the natural fracture system; and

- Establishing an optimal well drainage geometry to best match permeability anisotropy and stimulation method.

6) Development of Six Regional Partitions for Ohio. Gas production estimates were made for each county using the geological and production data developed in Steps 2 through 5, above. The state of Ohio was then partitioned into six overall areas (partitions) based on 40-year cumulative gas production, and the key geological parameters and tectonophysics that establish the natural stress and fracture regimes, as shown on Exhibit 1. 
Exhibit 1

\section{PRIMARY PARTITIONED AREAS DEVONIAN GAS SHALES OF OHIO}

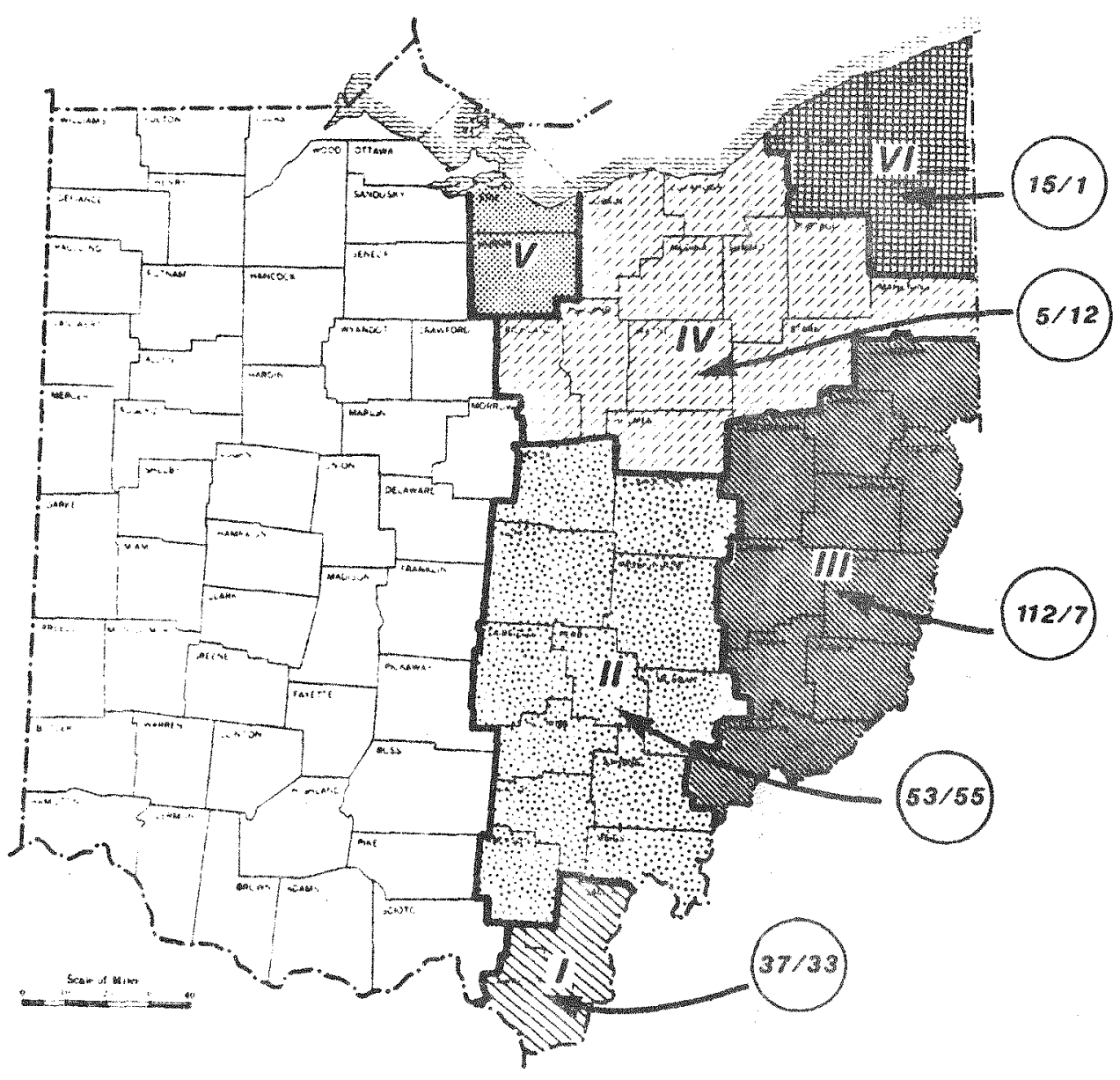

* NUMEEA OF OPENFLLW GAS PRODUCTION RECOADS * Number of long-term gas production aecondos

AVERAGE GEOLOGIC PROPERTIES BY AREA

\begin{tabular}{|c|c|c|c|}
\hline $\begin{array}{l}\text { PARTITIONED } \\
\text { AREA }\end{array}$ & $\begin{array}{l}\text { FRACTUAE } \\
\text { SPACING }\end{array}$ & $\begin{array}{l}\text { PEPMEABUIYY } \\
\text { ANISOTAOPY }\end{array}$ & $\begin{array}{l}\text { WTERSECTION } \\
\text { ANGLE }\end{array}$ \\
\hline & (toe!) & Tretiol & (000005) \\
\hline 1 & 10 & $1: 1$ & N/A \\
\hline y & 20 & $6: 1$ & 10 \\
\hline MII & 20 & A: & 20 \\
\hline WV & 20 & $6: 1$ & AD \\
\hline v & 20 & $8: 1$ & 40 \\
\hline$V_{1}$ & 20 & $8: 1$ & 40 \\
\hline
\end{tabular}


7) Development of Representative Data by Partitioned Area. The essential geological data were aggregated and compiled by each of the six partitioned areas, as summarized on the bottom of Exhibit 1 .

8) Delineation of Al ternative Stimulation Cases. Four well stimulation techniques, beyond traditional borehole shooting, were evaluated:

- Small Radial Stimulation $\left(r_{W}^{\prime}=30\right.$ feet): attainable with emerging technological improvements in omni-directional stimulation;

- Large Radial Stimulation $\left(r_{w}^{\prime}=60\right.$ feet): potentially attainable with major improvements in explosive and propellant technology;

- Small Vertical Fracture $\left(x_{f}=150\right.$ feet $)$ : attainable, but not yet fully controllable or predictable with current technology; and

- Large Vertical Fracture $\left(x_{f}=600\right.$ feet $)$ potentially attainable wi th significant advances in technology or alternate fracture fluids and proppants.

The results of the analysis were then assembled according to a Base Case that examined gas production using borehole shooting, and a series of Advanced Cases that examined the effects of using the above more-extensive well stimulation treatments. 
SUMMARY OF FINDINGS. Six major findings emerge from this study:

1. Based on Geologic Characteristics, Tectonophysics, and Simulated Gas Production, the State of Onio Was Partitioned Into Six General Areas. These areas have been ranked by production, as Areas I to VI and are shown on Exhibit 1.

2. The Devonian Shales of Ohio Offer a Major Source of Technically Recoverable Natural Gas. Recoverable gas in Ohio was estimated for each of the six partitioned areas, Exhibit 2. In total, recoverable gas ranges from 6.2 to 15.2 Tcf over 40 years (depending on stimulation) from wells drilled on 160-acre spacing in the Midd1e and Lower Huron members. Avera ge production per well was found to be highest in southern ohio (Area I) and to generally decline nor theastward over the state.

3. It Will Take a Major Drilling Effort, From 44 to 88 Thousand Wells, to Produce the Technically Recoverable Gas. Given an undrilled, accessible area of nearly 11,000 square miles $(7$ million acres), it would take 43,970 wells on 160-acre spacing, or 87,940 wells on 80 -acre spacing, to fully develop and produce the technicaliy recoverable gas in thio from the target intervals.

4. Improved Stimulation Technology is Required to Unlock the Full Gas Potential. Use of large vertical fractures, in the high gas potential Area I, will provide per well cumulative recoveries (over 40 years) of 1,080 Micf versus 386 Micf by borehole shooting. Even in the low gas potential Area VI, large radial stimulation would more than double the gas flow rates and ultimate recovery, as compared with borehole shooting. Other advances, for more efficiently interconnecting the full natural fracture system to the wellbore, would further increase gas recovery. 
5. Alternative Well Spacing and Pattern Configuration Will Help Increase Recovery. Reduced well spacing to 80 acres per well will al so increase gas recovery (from 15.2 Tcf at 160 acres to 22.5 Tcf at 80 acres) without appreciably reducing gas recovery in the initial years. In addition, when using one of the improved stimulation methods, changing the pattern alignment to a 3 by 1 rectangle instead of a square will add from 5 to 10 percent recovery per well.

6. A Considerable Amount of Geological/Geophysical Data is Required to Properly Simulate the Gas Production Mechanism of the Devoni an Shales. Beyond the conventional gas storage and production mechanisms, the major controlling factors in the Devonian shale include fracture permeability and intensity, permeability anisotropy, adsorbed gas, the capacity to connect the natural fracture system to a wellbore, and the difficult-to-measure (by conventional means) net productive interval. While recent work has begun to provide some of this data, a considerable amount of extrapolation and reliance on assumption was required for this study. Substantial future research and drilling is required to further increase the understanding of gas production from Devonian shales.

Exhibit 2 provides a summary of the gas in-place and technically recoverable gas, by area and stimulation method. The fact sheets which follow this exhibit present further detail on the reservoir properties, gas potential, cumulative gas recovery, and production decline curves for the six partitioned areas of onio. 


\section{Exhibit 2}

TECHNICALLY RECOVERABLE GAS, BY AREA AND STIMULATION METHOD

TECHNICALLY RECOVERABLE GAS (TCF) IN 40 YEARS

\begin{tabular}{|c|c|c|c|c|c|c|c|}
\hline $\begin{array}{l}\text { PARTITIONED } \\
\text { AREA }\end{array}$ & $\begin{array}{c}\text { TOTAL } \\
\text { DRILLABLE } \\
\text { AREA }\end{array}$ & $\begin{array}{l}\text { GAS IN } \\
\text { PLACE }\end{array}$ & $\begin{array}{l}\text { BOREHOLE } \\
\text { SHOOTING }\end{array}$ & $\begin{array}{c}\text { SMALL } \\
\text { RADIAL } \\
\text { STIMULATION } \\
r_{W}^{\prime}=30^{\prime}\end{array}$ & $\begin{array}{c}\text { LARGE } \\
\text { RADIAL } \\
\text { STIMULATION } \\
r_{W}{ }_{W}=60^{\circ}\end{array}$ & $\begin{array}{l}\text { SMALL } \\
\text { VERTICAL } \\
\text { FRACTURE } \\
X_{f}=150^{\circ}\end{array}$ & $\begin{array}{l}\text { LARGE } \\
\text { VERTICAL } \\
\text { FRACTUAE } \\
X_{f}=600^{\circ}\end{array}$ \\
\hline & (SQ. MI.) & (TCF) & & & & & \\
\hline 1 & 543 & 4.1 & 0.84 & 1.16 & 1.41 & 1.58 & 2.35 \\
\hline$\|$ & 3,577 & 12.4 & 2.95 & 4.06 & 4.64 & 4.67 & 6.21 \\
\hline III & 2.869 & 4.4 & 1.46 & 1.98 & 2.25 & 2.33 & 3.04 \\
\hline IV & 2,641 & 24.8 & 0.84 & 1.35 & 1.73 & 1.78 & 3.38 \\
\hline v & 313 & 0.4 & 0,05 & 0.06 & 0.06 & 0.06 & N.A. \\
\hline VI & 1,035 & 3.3 & 0.04 & 0.07 & 0.10 & 0.09 & 0.20 \\
\hline TOTAL & 10,978 & 49.4 & 6.18 & 8.68 & 10.19 & 10.52 & 15.18 \\
\hline
\end{tabular}


SUMMARY OF OHIO DEVONIAN SHALE GAS POTENTIAL

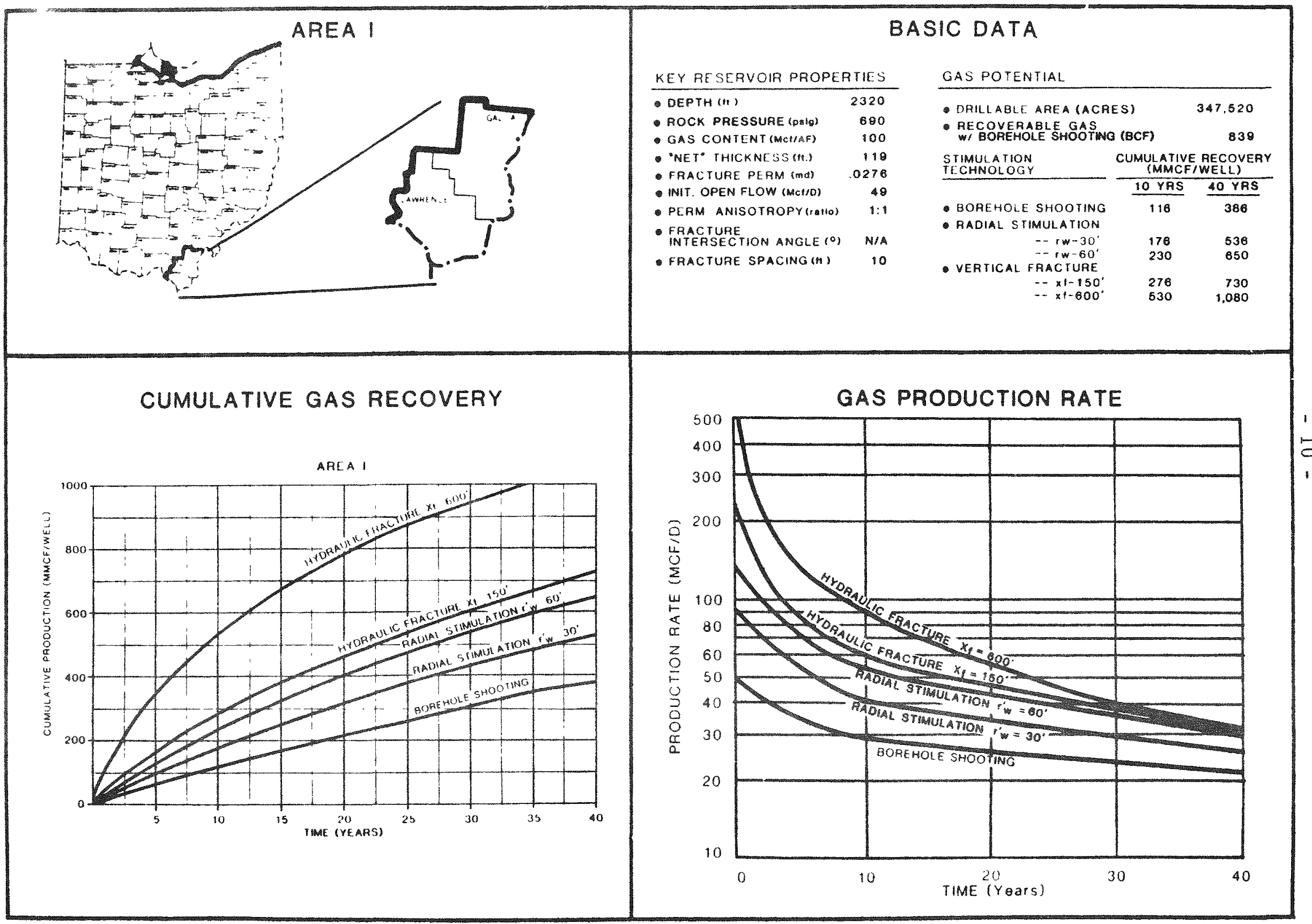


SUMMARY OF OHIO DEVONIAN SHALE GAS POTENTIAL

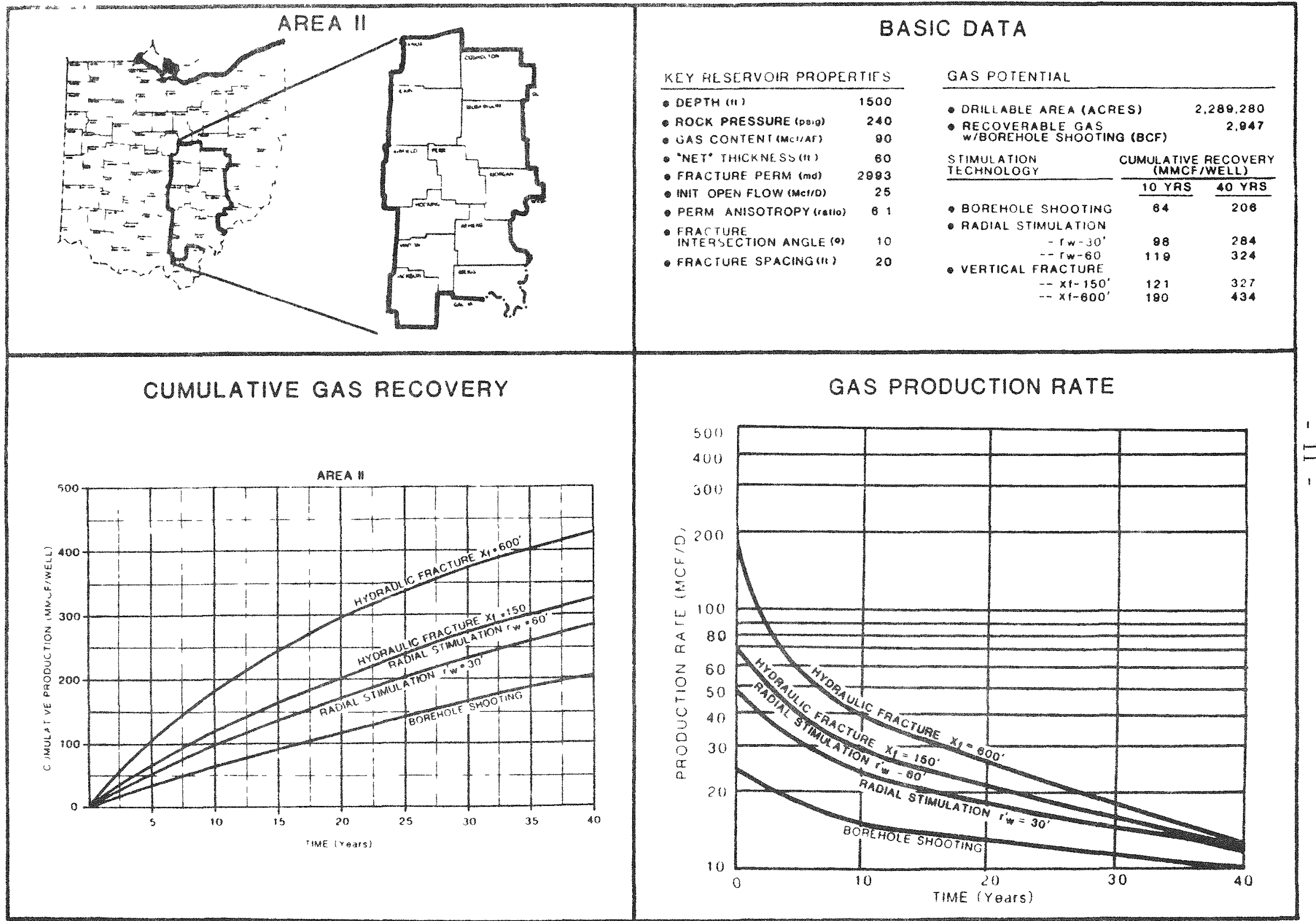


SUMMARY OF OHIO DEVONIAN SHALE GAS POTENTIAL

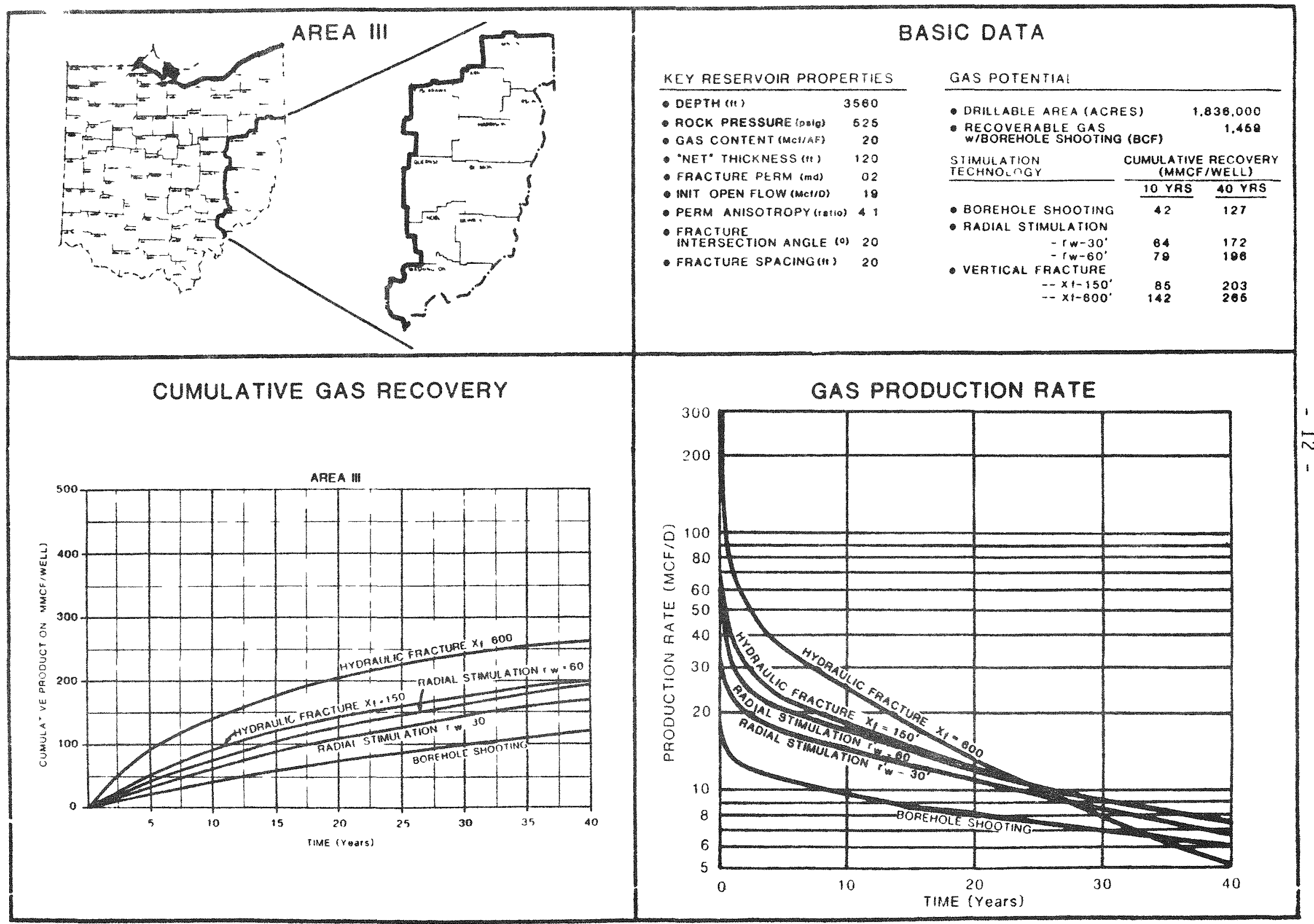


SUMMARY OF OHIO DEVONIAN SHALE GAS POTENTIAL

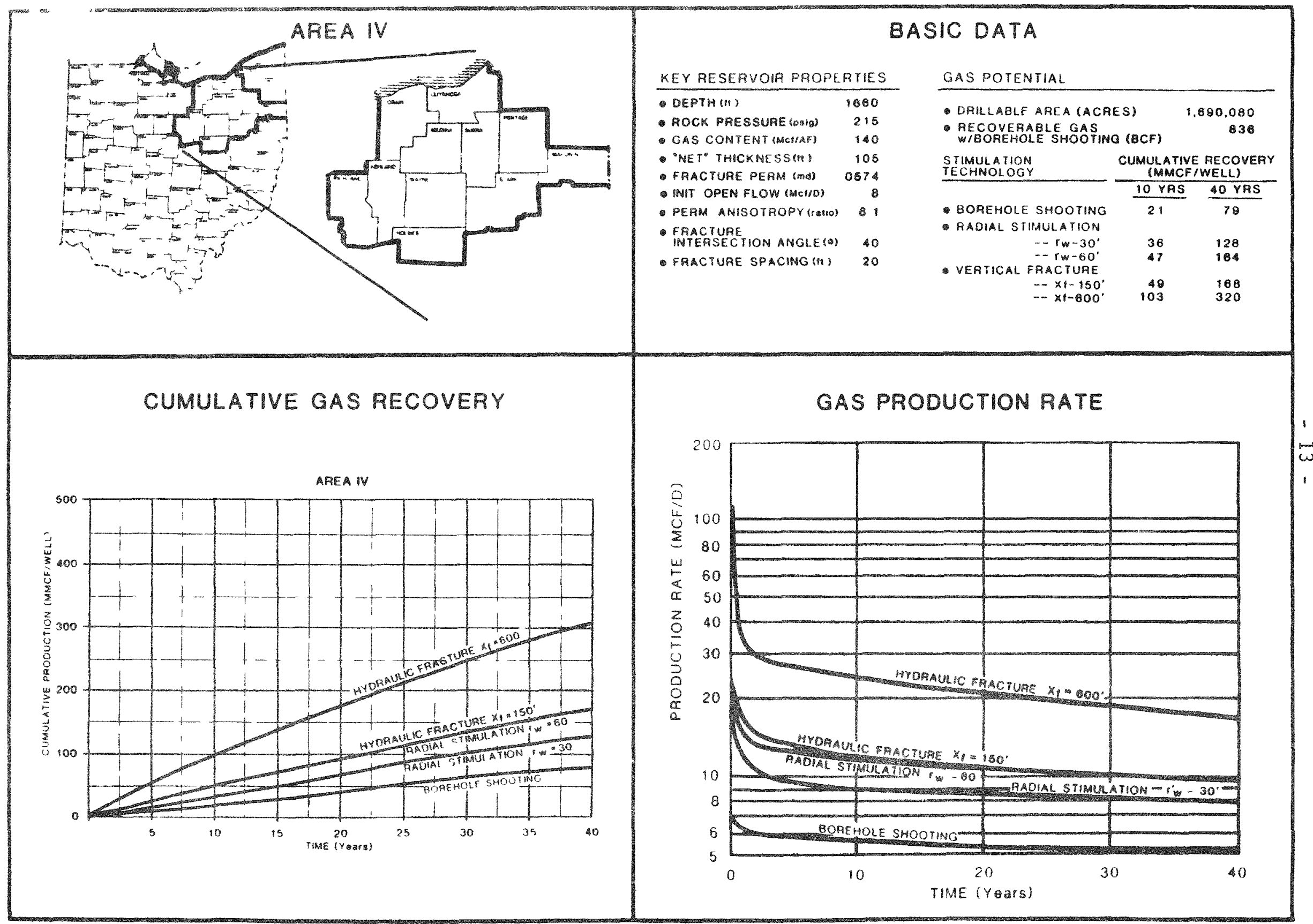


SUMMARY OF OHIO DEVONIAN SHALE GAS POTENTIAL

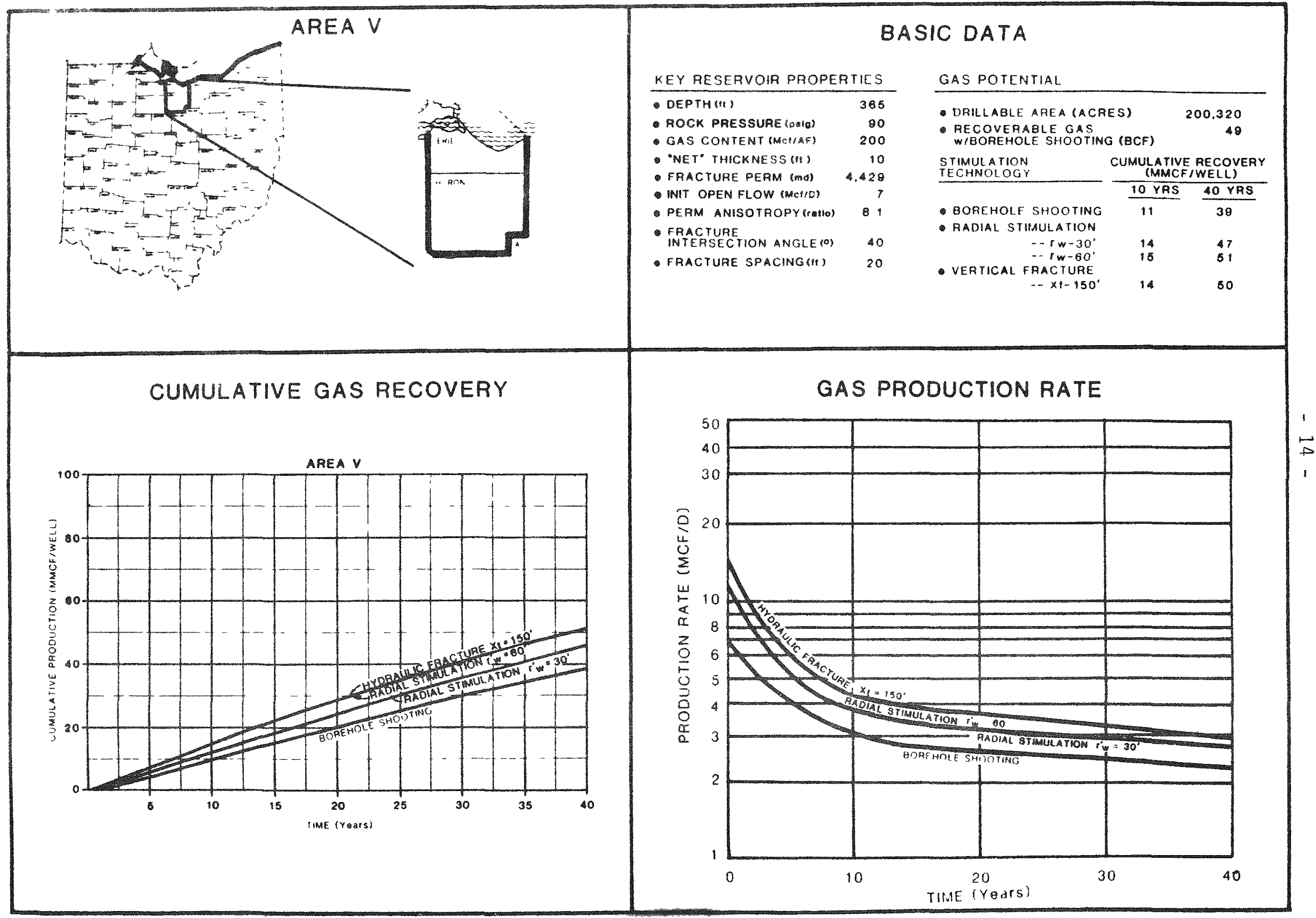




\section{SUMMARY OF OHIO DEVONIAN SHALE GAS POTENTIAL}

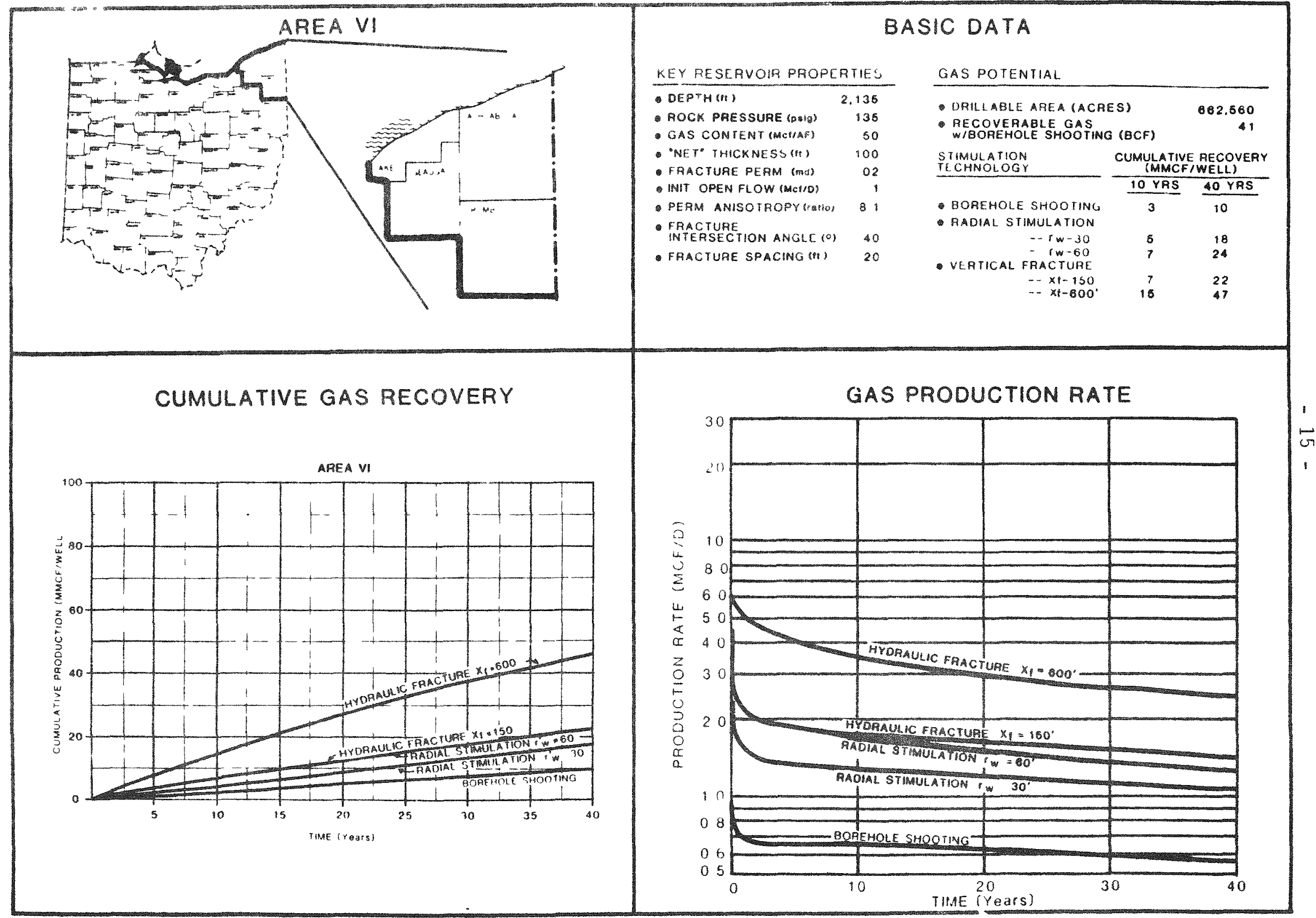




\section{HIS TOR ICAL BACK GROUND}

Devonian shales constitute one of the iargest worldwide concentrations of organic carbon. Recent estimates of the total gas in-place range from 844 Tcf to 2,579 Tcf, as determined by the U.S. Geological Survey and Mound Facility, respectively. However, the resource potential and technological challenges of efficiently recovering and economically producing the hydrocarbons locked in the Devonian shales are formidable and have yet to be solved.

The geologic setting of the Devonian shales is highly complex. The shales are a combination of source bed, reservoir, and seal in multiple stratigraphic horizons. Gas production is dominated by natural fractures and other permeability channels. The resource includes free gas in the natural fracture system and in the rock matrix, plus adsorbed gas on the surfaces of the organic kerogen. Of these three sources, adsorbed gas accounts for the largest share, approximately $85 \%$ of the total gas in-place.

To date, full development of this resource has been impeded by a lack of scientific description and analysis of the gas production mechanisms in the organic shales. Conventional geological and engineering measures of the drainage area, net productive interval, permeability, and porosity need to be supplemented by improved geological models of the natural fracture system, permeability anisotropy, and the release of adsorbed gas.

In addition, efficient development has been constrained by limitations in extraction and well stimulation technologies and Iimited understanding of how stimulation technologies perform in the naturally fractured, anisotropic shate rocks.

Recently, a number of major studies and activities have been completed under the Eastern Gas Shales Project (EGSP) that provide a basis for advancing the understanding of the Devonian gas shales. Under the 
sponsorship of the U.S. Department of Energy's Morgantown Energy Technology Center (DOEMETC), two geological and geochemical assessments of the Devonian shales have been completed by the Mound Facility and Cliffs Minerals, name ly:

- "Resource and Exploration Assessment of the 0il and Gas Potential in the Devonian Gas Shales of the Appalachian Basin," 1982, Mound Facility. ${ }^{1}$

- "Basin Analysis of the Devonian Shales in the Appalachian Basin," June 1982, Cliffs Minerals."

Their detailed reports provide much information as to the fracture system, stratigraphic sequence and gas content of the shale. In addition, DOEMETC has developed a reservoir simulator called SUGAR (Simulator for Unconventional Gas Resources) that is capable of handling many of the unique features of the shale not commoniy found in other simulators, such as dual porosity, fracture flow, and permeability ani sotropy. ${ }^{3}$

Paralleling the analytic work has been a series of field research projects, such as the offset Well Test Program (OWTP) ${ }^{4}, 5$ in Miegs County, on io to identify the net productive interval and permeability anisotropy; the drilling of a deviated well to measure natural fracture spacing; and, the drilling of a series of Eastern Gas Shates Program (EGSP) core wells to establish basic data on shale porosity, permeability, and organic carbon content.

Finally, there has been a recent upsurge in drilling, testing, and well stirulation by industry that is yielding new data on previously undrilled areas of the Appalachian Basin. 


\section{STUDY PURPOSE, APPROACH, AND METHODOLOGY}

\section{A. KEY TECHNICAL QUESTIONS}

Building on the accomplishments of the previous research, it becomes appropriate to examine the remaining key technical questions in order to determine the gas reserves, such as:

- How to properly characterize and interpret the gas production mechani sm;

- How to select the productive interval consistentiy in areas of favorable gas potential;

- What types of well stimulation techniques to use or develop further with additional research; and

- How to reliably estimate gas flow rates and ultimate recovery.

\section{B. STUDY PURPOSE}

The current study begins to address these questions by integrating the previous research work and collecting additional data toward the following five study objectives:

1) A rigorous investigation, model development, and description of the gas production mechanisms in the Devonian gas shales. This study examines the gas storage and production mechanisms in the naturally fractured, dual porosity systems that govern productivity in Devonian shales beyond the conventional mechanisms of drainage area, net pay, porosity, permeability, and pressure. 
2) The collection and assembly of essential geologic and reservoir data. While much of the data required for this analysis is assembled from previous research, it is augmented by the collection of new data on well completion and gas production.

3) The partitioning of the state into study regions. For the purposes of analysis, the state of onio is partitioned into regions based on geologic data and gas production trends.

4) An investigation of the efficiency of alternative well stimulation and production strategies. The relative efficiencies of borehole shooting, radial stimulation, and vertical fracturing are analyzed using a numerical reservoir simulator specifically designed for the key production features of the Devonian shales.

5) An estimate of the technically recoverable reserves in onio. Technically recoverable reserve estimates are made for each of the major partitioned areas of ohio, for various stimulation techniques; the target interval of this analysis will be the Middle and Lower Huron shale memeers of the Upper Devonian ohio Shale.

This report builds and improves on the technologic knowledge base to provide a scientific understanding of the Devonian Shales Gas resource. It's primary audience is intended to be a explorationists, geologists, and R\&D Managers interested in a detailed basin level analysis of the resource along with independent operators interested in choosing a stimulation technique in a given area. The purpose of this study is to examine the se issues in a regional setting. Therefore, the findings of this study are not intended to be representative of any specific lease or well location in the state. 


\section{GENERAL APPROACH}

The general approach used by this study is to build on the existing knowledge gained in the last six years from the DOE Eastern Gas Shales Program (EGSP), and in particular from the several important pieces of work recently concluded under the sponsorship of DOEMETC. The Mound report, Cliffs Minerals studies, and the results and analyses of the offset Well Test Program are used as primary sources of geologic data for this study. In addition, gas production and open flow data generated from the recent upsurge of drilling in the Appalachian Basin are used to supplement the primary sources.

These data are used to develop a representative data set for each county in onio for the target interval. Several reservoir parameters do not vary widely and are kept constant over the study area. Other reservoir parameters that show regional variations are individually calculated for each county using actual data or extrapolation from neighboring counties. Isoline maps are developed for these data using information from the known counties with documented data as control points.

The SUGAR simulator is used to match production data and backcalculate the remaining unknown reservoir parameters. It is also used to validate the other reservoir parameters using a history matching approach, comparing the simulated production and historical production records. In this manner the geologic/reservoir data are developed; fur thermore, the data sets are comparable.

Base case gas production forecasts are made for each county using the SUGAR simulator and the data developed. Ohio is then partitioned into "comparable" areas based on 40-year cumulative production, joint-stress relationships, tectonophysics, and the mechanical fabric of the shales. The effect of improved well stimulation, due to vertical fracturing and radial stimulation, are modeled for each of the partitioned areas to analyze the relative efficiencies of each method. Finally, a series of additional 
analyses are performed to better assess the importance of the key assumptions used in this study and to take into account other factors affecting production.

D. METHODOLOGY

The methodology closely followed the general approach and consisted of eight major steps, as discussed below:

1) Identification of Constant Geologic/Reservoir Data. Several reservoir parameters, such as matrix permeability and porosity, were found not to vary widely and thus were kept constant over the study area. These reservoir data and parameters were assembled from:

- Historical gas production and well records,

- The EGSP core well program, and

- The offset Well Test Program (Meigs County, Ohio)

2) Development of Variable Geologic Data By County. Reservoir parameters that showed strong regional variation, such as gas content and pressure, were developed for each county from actual data or were extrapolated from a series of isoline maps developed for Ohio. These data were based on:

- Geological and geochemical reports by Cliffs Minerals and Mound Facility:

- Fracture conductivity studies by Terra Tek: ${ }^{6}$

- Stressuratio maps prepared by METC/DOE; ${ }^{7}$ and

- Rock pressure data from 257 wells in 15 counties. 
3) Assembly of Actual Gas Production Data. Historical gas production data for Ohio were gathered from state and company records, as follows:

- Long-term production data were assembled from 108 wells in 11 counties; and

- Initial open flow ( $24 \mathrm{hr}$, ) data were collected from 222 wells in 15 counties.

4) History Matching of Production Data and Productive Interval. A reservoir simulator entitled Simulator for Unconventional Gas Recovery (SUGAR) was used to match production data and back-calculate the remaining unknown reservoir parameters of fracture permeability and net productive interval, as well as to ensure consistency in the basic data.

5) Definition of the Fracture Regimes. Beyond the data required for analyzing the performance of well stimulation by borehole shooting, additional geological data were required to properly evaluate well performance with improved stimulation technology. This additional data included:

- Determining directional components of fracture permeability to reflect permeability ani sotropy;

- Identifying the expected angle of intersection between induced and natural fractures to estimate whether the induced fracture will cross or terminate in the natural fracture system; ${ }^{8}$ and

- Establishing an optimum well drainage geometry to best match permeability ani sotropy and stimulation method. 
6) Development of Six Regional Partitions for Ohio. Gas production estimates were made for each county using the geologic and production data developed in Steps 2 through 5, above. The state of Ohio was then partitioned into six areas based on 40-year cumulative gas production, and the key geological data that establish the natural stress and native fracture distribution.

7) Development of Representative Data by Partitioned Area. The essential geologic data were aggregated and compiled by each of the six partitioned areas.

8) Delineation of Alternative Stimulation Cases. Four well stimulation techniques, beyond traditional borehole shooting, were evaluated:

- Small Radial Stimulation $\left(r^{\prime}=30\right.$ feet $)$ attainable with emerging technological improvements in omni-directional stimulation;

- Large Radial Stimulation $\left(r_{w}^{\prime}=60\right.$ feet): potentially attainable with major improvements in explosive and propellant technology;

- Small Vertical Fracture $\left(x_{f}=150\right.$ feet $)$ : attainable, but not yet fully controllable or predictable with current technology; and

- Large Vertical Fracture $\left(x_{f}=600\right.$ feet $)$ potentially attainable with significant advances in technology or alternate fracture fluids and proppants.

At the conclusion of these steps, the data which had been assembled by area was analyzed for each of the delineated stimulation cases using the SUGAR Model. 


\section{COLLECTION AND ASSEMBLY OF DATA}

This chapter details the collection of the essential geologic and reservoir data on the Devonian shales of the Appalachian Basin, the assembly of representative data for Ohio by county, and the use of the data to estimate technically recoverable reserves of Devonian shale gas in ohio.

\section{A. IDENTIFICATION OF GEOLOGIC/RESERVOIR DATA}

The required geologic/reservoir parameters and their sources are discussed below:

1. Parameters Required

History matching of long-term production data revealed that the following parameters are required to properiy characterize the productive mechanism for Devonian shales:

- Drainage Area $(A)$; acres

- Matrix Permeability $\left(k_{m}\right)$; md

- Matrix Porosity $\left(\Phi_{\mathrm{m}}\right)$; percent

- Fracture Porosity $\left(\Phi_{f}\right)$ : percent

- Gas Content $\left(G_{C}\right)$; scf/cf

- Rock Pressure $\left(P_{j}\right)$; psia

- Line Pressure $\left(P_{\eta}\right)$; psia

- Fracture Spacing (a); feet

- Natural Fracture Permeability $\left(k_{f}\right)$; md

- Productive Thickness (h): feet

In addition, to calibrate the model, initial open flow and cumulative gas production data were required. 
2. Sources of Data

The major sources of data used in this study were:

- Historical gas production records

- Offset Well Test Program

- Mound report

- Cliffs report

These sources are discussed in further detail below:

a. Historical Production Records--Production and Reservoir Data. A 1 arge number of well records were obtained from the Ohio Geological Survey and gas production companies. Approximately 900 records of wells that penetrated or were completed in the Devonian shale, spanning the time period from 1898 to 1981 , were screened for usable rock pressure and initial open flow data. of these, approximately 300 wells in 22 countries contained usable data for the study.

Initial production data were acquired for 15 counties, as shown below:

\begin{tabular}{lc} 
County & $\begin{array}{c}\text { Number of Wells With } \\
\text { Open Flow Production Data }\end{array}$ \\
\cline { 2 - 2 } Athens & 5 \\
Ashtabula & 4 \\
Belmont & 2 \\
Carroll & 2 \\
Columbiana & 1 \\
Gallia & 7 \\
Knox & 3 \\
Lawrence & 30 \\
Licking & 26 \\
Lorain & 5 \\
Meigs & 19 \\
Monroe & 18 \\
Noble & 22 \\
Trumbull & 11 \\
Washington & 67 \\
TotAL & 222
\end{tabular}


The locations of the wells that provided initial and long-term gas production data are shown on Exhibit 3. A detailed description of data sources and location is provided in Appendix A.

The bulk of the long-term production data, consisting of 108 wells in 11 counties, were obtained from proprietary company sources and data supplied by DOE/METC. The data included wells with initial flow cormencing as early as 1922 and as late as 1976. The county-by-county tabulation of the long-term gas production data is provided below:

\begin{tabular}{lc} 
County & $\begin{array}{c}\text { Number of Wells With } \\
\text { Long-Term Production Data }\end{array}$ \\
\cline { 2 - 2 } Cuyahoga & 1 \\
Lawrence & 33 \\
Licking & 27 \\
Meigs & 25 \\
Medina & 10 \\
Monroe & 7 \\
Morgan & 1 \\
Muskingum & 1 \\
Perry & 1 \\
Richland & 1 \\
Trumbul1 & 1 \\
TOTAL & 108
\end{tabular}

Al though earlier studies indicated the availability of 1 arger quantities of data, the records above represent the latest data set as compiled by the Ohio Geological Survey. Many wells which were not truly producing from the shale have been deleted.

b. Offset We1l Test Program--Fracture and Rock Matrix Properties. An extensive well test program (OWTP) was conducted in Meigs County, Ohio, during 1980 and 1981. The test included drawdown and buildup interference testing between a borehole shot producing well and two offset wells. The base well was originally stimulated by borehole shooting and has a long-term production history. The two of fset wells were drilled at approximately 90 degree angles relative to the producing well. 
Exhibit 3

\section{AVALABILTTY OF PRODUCTION DATA BY COUNTY}

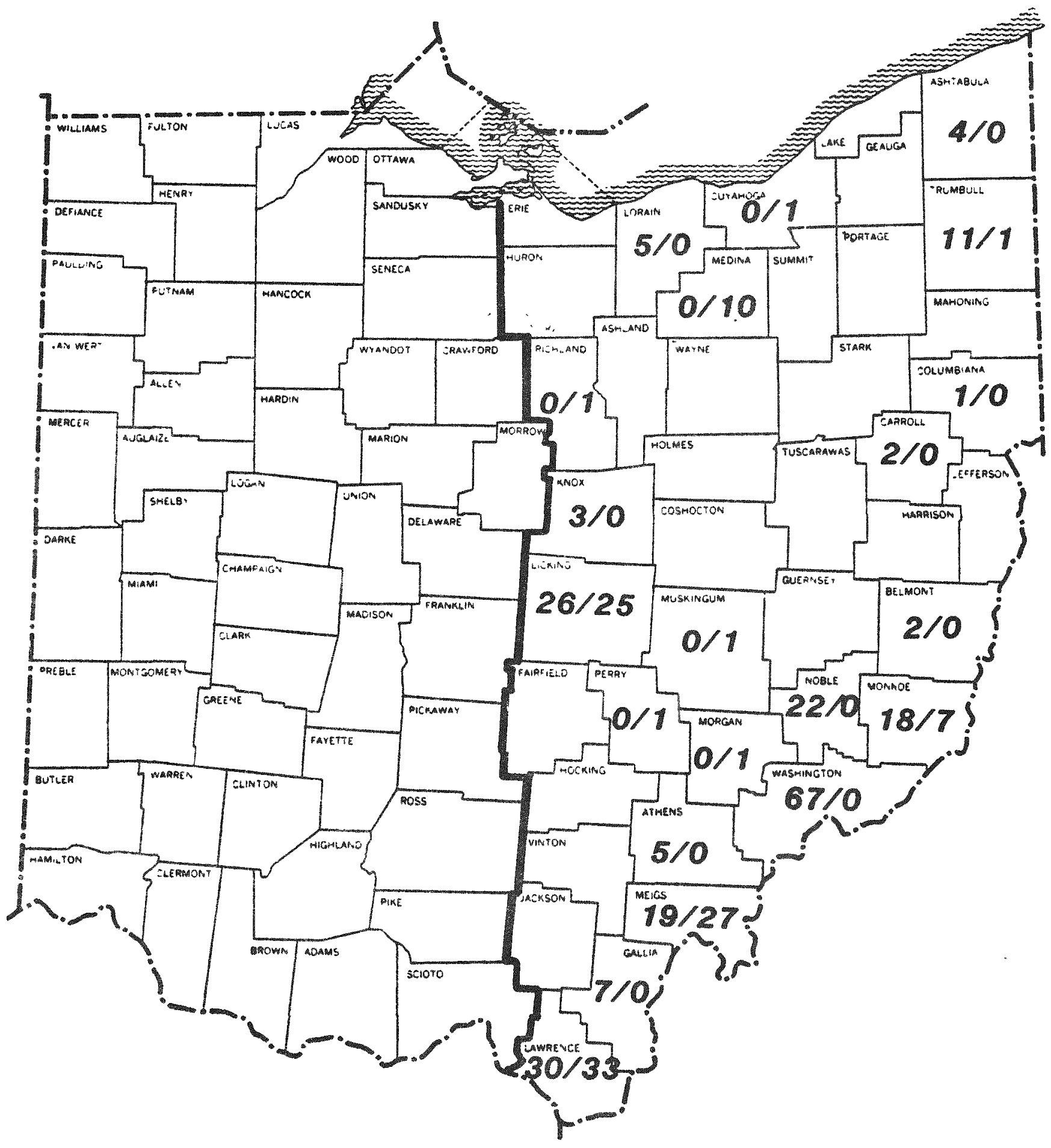

at 2 ats

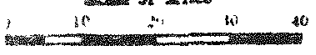

* NUMBER OF OPENFLOW GAS PRODUCTION RECORDS

(* NUMBER OF LONG-TERM GAS PRODUCTION RECORDS 
The first offset we11 (OH-9) was cored from about 2,923 feet to near the base of the Huron shale at 3,373 feet. Porosity and permeability measurements on selected core samples were made by Core Laboratories in Dallas, Texas and Monsanto Research Corporation's Mound Facility in Mi amisburg, Ohio.

In addition, the OWTP site served as a control and calibration point for calculations of permeability ani sotropy, fracture permeability, and fracture spacing for the state.

c. Mound Report--Geochemical Data. The recently completed report, Resource and Exploration of the Devonian Gas Shales by Mound, provided the necessary information on free and sorbed gas content. The major aspects of this study are summarized below:

- Detailed physiochemical analysis was performed on over 2,000 samples from ECSP core wells; samples were selected at 10 to 20-foot intervals in each of the EGSP core wells.

- A controlled-offgassing procedure was developed and validated via comparison with pressure core barrel measurements.

- The shale interval (Upper Devonian age rock) was subdivided into 17 stratigraphic units, as identified in Table 1.

- Algorithms were developed for calculating indigenous gas in-place, based on organic carbon content, thermal alteration index (TAI) and organic matter origin.

The locations and a detailed description of the EGSP core wells used in the Mound and Cliffs studies may be found in Appendix B.

d. Cliffs Report--Geologic Data. The majority of the geologic data were obtained from the report, Basin Analysis of the Devonian Shales in the Appalachian Basin by Cliffs Minerals. 
Table 1

STRATIGRAPHIC DEVONIAN SHALE UNITS

\begin{tabular}{|c|c|c|c|c|}
\hline SYSTEM & SERIES & STAGE & $\begin{array}{l}\text { STRATI- } \\
\text { GRAPHIC } \\
\text { UNIT }\end{array}$ & PHASE/UNIT \\
\hline \multirow{5}{*}{$\begin{array}{l}z \\
< \\
w \\
z \\
0 \\
= \\
w \\
0\end{array}$} & Upper & Ohio Shale & $\begin{array}{l}17 \\
16 \\
15 \\
14 \\
13 \\
12 \\
11 \\
10\end{array}$ & $\begin{array}{l}\text { Cleveland } \\
\text { Chagrin } \\
\text { Late Upper Huron } \\
\text { Early Upper Huron } \\
\text { Late Middle Huron } \\
\text { Early Middle Huron } \\
\text { Late Lower Huron/Late } \\
\text { Dunkirk } \\
\text { Early Lower Huron/Early } \\
\text { Dunkirk }\end{array}$ \\
\hline & Middle & $\begin{array}{c}\text { Oientangy } \\
\text { Shale }\end{array}$ & $\begin{array}{l}9 \\
8 \\
7 \\
7\end{array}$ & $\begin{array}{l}\text { Upper Olentangy/Java } \\
\text { FM./Hanover } \\
\text { Middle Olentangy/Angola } \\
\text { Shale } \\
\text { Late Lower 0lentangy/Late } \\
\text { Rhinestreet } \\
\text { Early Lower Olentangy/Late } \\
\text { Rhinestreet }\end{array}$ \\
\hline & \multirow{3}{*}{ Lower } & Genesee & $\begin{array}{l}5 \\
4\end{array}$ & $\begin{array}{l}\text { Sonyea/Mi ddlesex } \\
\text { Genesee/Geneseo }\end{array}$ \\
\hline & & Mamil ton & 3 & $\begin{array}{l}\text { Hamil ton Group/Post- } \\
\text { Marcellus }\end{array}$ \\
\hline & & Marcellus & $\begin{array}{l}2 \\
1\end{array}$ & $\begin{array}{l}\text { Late Marcellus } \\
\text { Early Marcellus }\end{array}$ \\
\hline
\end{tabular}


In September 1980, Cliffs Minerals, Inc., a division of the Cleveland-Cliffs Iron Company, launched a major integration program to analyze geologic and engineering data that were accumulated by many contractors under the Eastern Gas Shales Project. The purpose was to identify areas with good hydrocarbon potential and delineate structural features. As part of this, a series of activities were undertaken by cliffs to define and give values to the geologic parameters affecting gas production from Devonian shales. These activities included:

- Regionar fracture (joint) studies,

- Stress analysis of the basin,

- Physical characterization of the shales,

- Definition of geologic structural features, and

- Lithologic and geochemical descriptions.

The Cliffs study was primarily used in this study to estimate permeability anisotropy, major and minor natural fracture orientation, and preferred orientation of induced fractures.

\section{B. DEVELOPMENT OF REPRESENTATIVE DATA BY COUNTY}

Geologic and reservoir data were divided into two categories in this study: (1) constant reservoir characteristics, and (2) variable reservoir characteristics. Those reservoir properties that were found not to vary widely across the state were fixed at constant values based on standard production practices and EGSP core well data. For reservoir properties that were found to vary across the state, data were collected on a county basis and extrapolated into counties where data were unobtainable.

\section{Constant Reservoir Characteristics}

a. Drainage Area. The traditional field development practice is to use a well spacing of 150 to 160 acres. The majority of the well records surveyed in this study indicated a well spacing of 160 acres, which became 
the Base case drainage area used in this study. The spacing was also chosen for analytical purposes in other reports, such as the NPC Devonian Shale report (Unconventional Gas Sources - Vol. III Devonian Shales, 1980). However, current practice is to drill on a closer spacing. To take this into consideration, the results of drilling on 80-acre spacing are examined in Chapter VII: Other Factors Affecting Production.

b. Target Interval. The productive interval analyzed in this study is composed of the Middle and Lower Huron units of the Ohio shale. Over 95 percent of the Devonian shale wells examined in this study were producing from this interval. This interval was also identified as the gas source in the Offset Well Test Project. The remaining wells were producing from the Cleveland and Chagrin units and had low gas production dedicated to domestic rather than commercial use.

c. Matrix Properties. Although a certain amount of variation in matrix properties was found, it was decided to use nominal values of $1 \%$ for shale matrix porosity and $5 \times 10^{-6} \mathrm{md}$ for matrix permeability. These values are based on measurements from the offset Well Test Program and supported by values from the other Ohio EGSP core wells. A sumary of the measurements made in support of the OWTP and the measurements from the ohio EGSP core wells are presented in Table 2.

d. Fracture Porosity. The porosity of the natural fracture system within the Devonian shales was determined quantitatively in Meigs County, Ohio as part of the Offset Well Test Program. From analysis of drawdown, build up, and interference tests, a nominal value of $0.09 \%$ was calculated, and values in the range of $0.01 \%$ to $0.5 \%$ were believed to be reasonable. Howi."ar, for lack of other data and because long-term production in the shale is essentially independent of fracture porosity, the value of $0.09 \%$ was used as a constant throughout the study. 


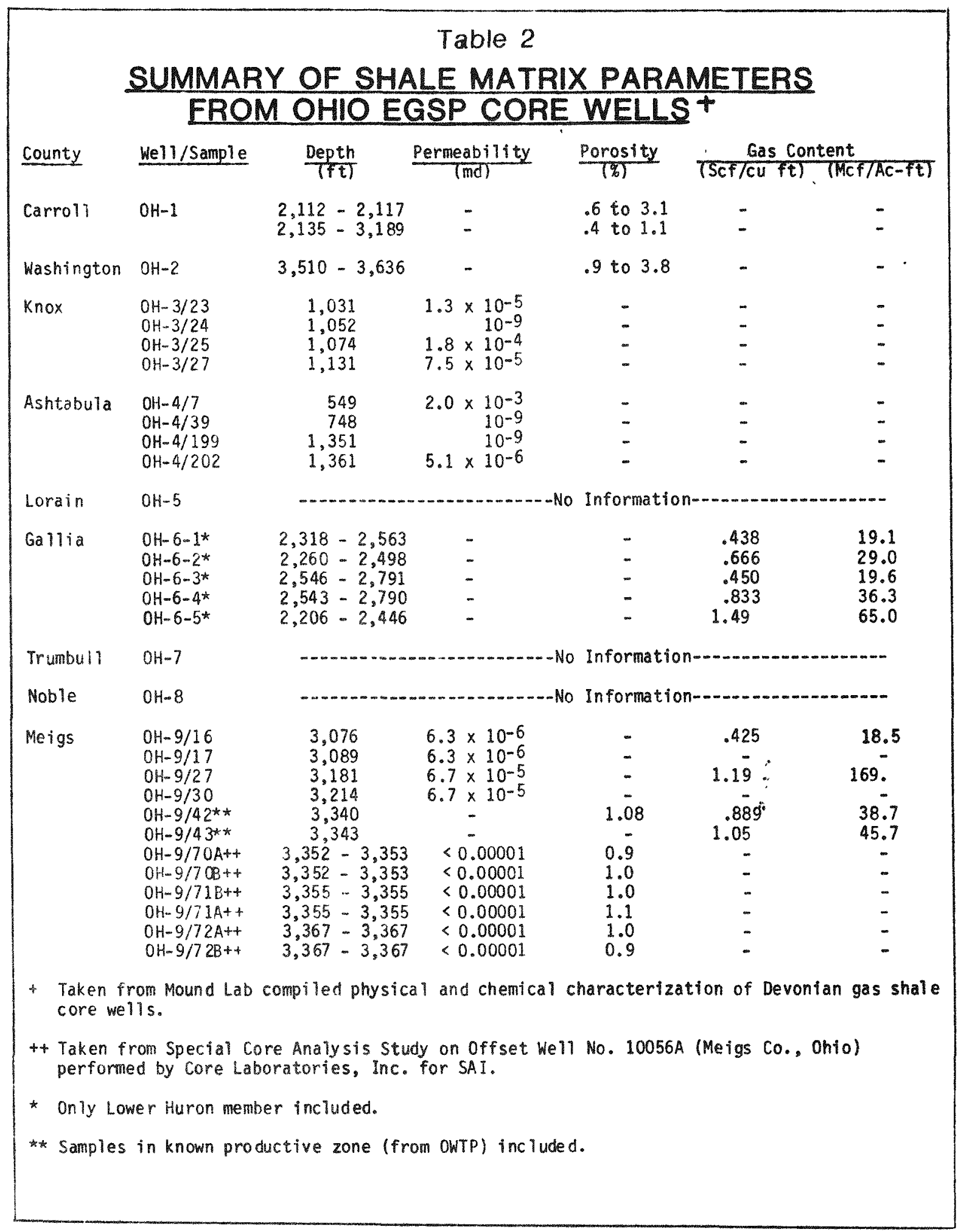




\section{Exhibit 4 \\ INITIAL OPEN FLOW \\ (Mcf/24 Hours)}

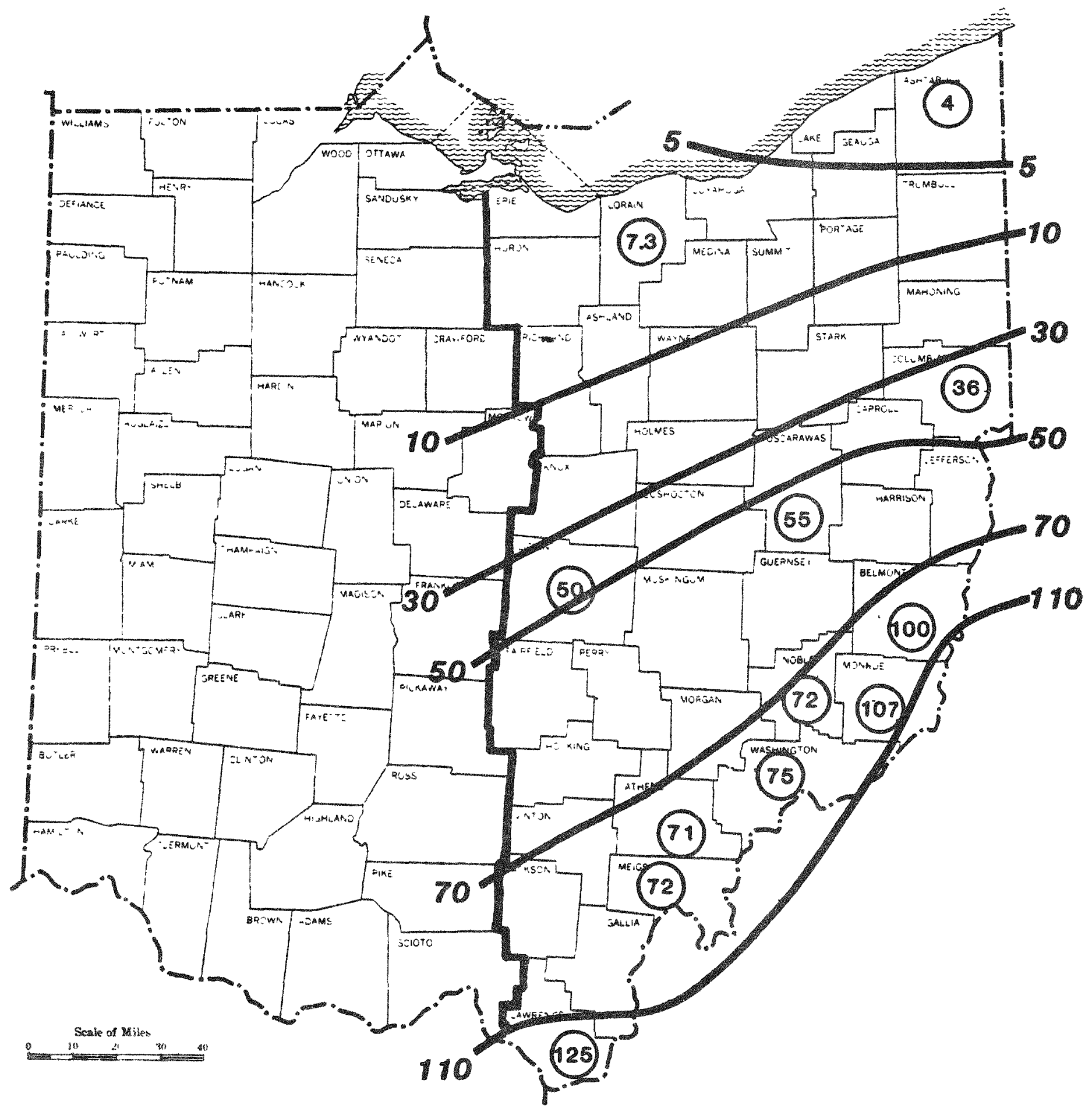




\section{Variable Reservoir Characteristics}

a. Initial Open Flow. Company well records and Onio Geological Survey well cards were reviewed and analyzed to determine the initial open flow rates. Data were available and validated for 12 counties. These records included data from both borehole shooting and fracturing. For those wells which were fractured, a productivity index ratio of 5 was utilized to convert initial flow to a borehole shot baseline level. While there is a considerable amount of error and variance in open flow data, the data were screened to eliminate any obvious outliers and anomalies. Data with in a county was averaged for the productive shale interval. The average values within a county produce a definite trend across the state. The resulting intial open flow isolines are shown on Exhibit 4.

b. Rock and Line Pressure. Initial rock pressure data were collected for 15 counties, from company well records and Ohio Geological Survey well cards. The data for each county were then averaged and used as control points in plotting a pressure isoline map, Exhibit 5 . The line pressure was based on the initial rock pressure, as shown on the following table:

\begin{tabular}{lc}
$\begin{array}{l}\text { Rock Pressure } \\
\text { (psia) }\end{array}$ & $\begin{array}{c}\text { Line Pressure } \\
\text { (psia) }\end{array}$ \\
\cline { 2 - 2 } Less than 100 & 25 \\
$100-300$ & 50 \\
Greater than 300 & 100
\end{tabular}

c. Gas Content. Basin gas content contour maps prepared by Mound for the Appalachian Basin were used to establish the starting point for estimates of the volume of "sorbed and free" gas for each of the 17 stratigraphic intervals identified. These maps included the thickness, organic carbon content, and thermal al teration index for each of the 17 stratigraphic units. 
Exhibit 5

ROCK PRESSURE (psig)

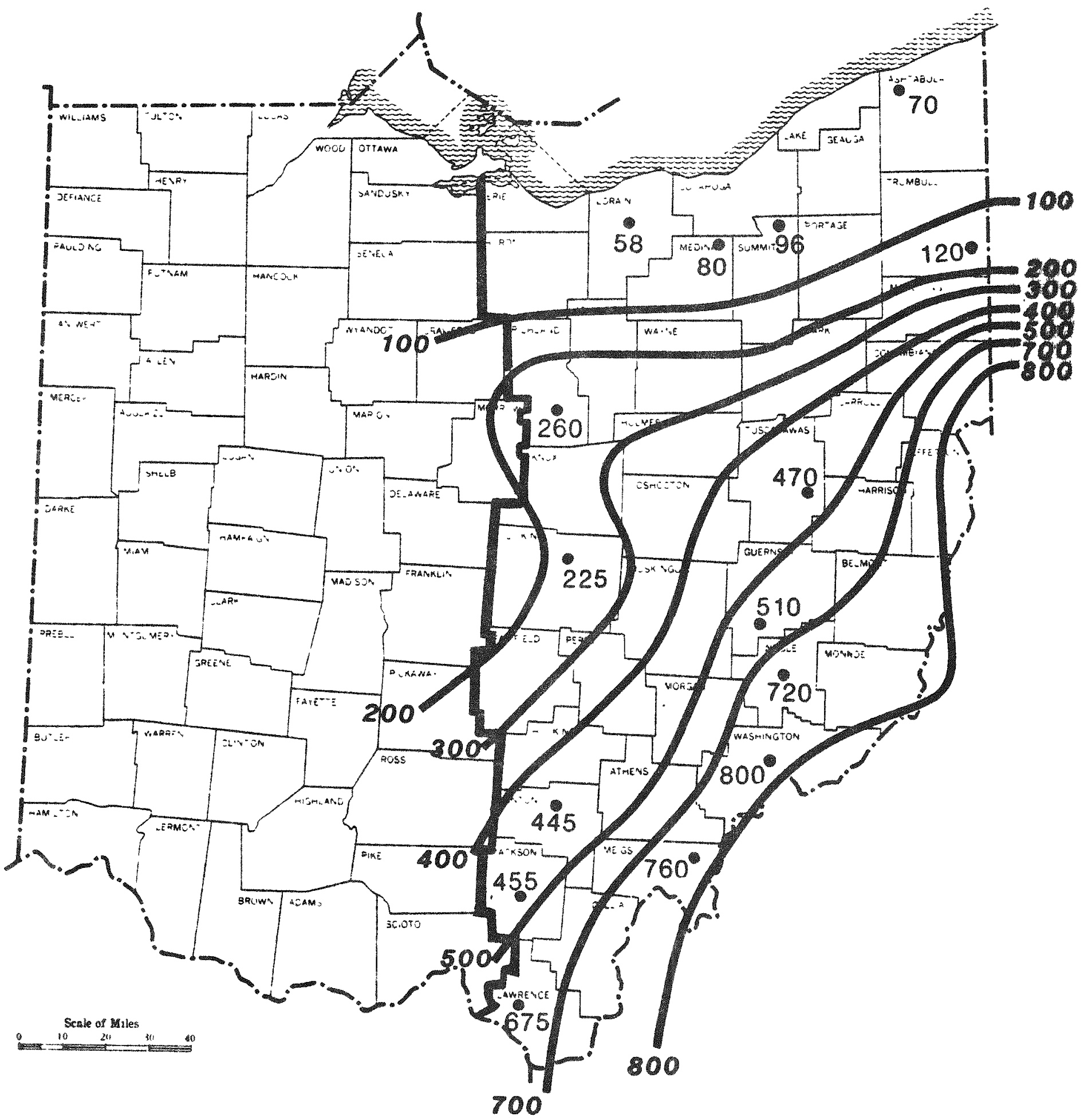

- Control Points in psig 
Exhibit 6 from the Mound report is representative of the gas content for one of the stratigraphic units, the Late Lower Huron member.

To obtain gas content data by county for use in the SUGAR simulator, the Mound contour maps were used to establish representative gas content values for each county. This refinement was done for each of the 17 stratigraphic units, including the three units in the Lower and Middle Huran members selected as the target intervais in this study.

Exhibit 7 shows an isoline map of gas content compiled by this study from the Mound maps for the Middle and Lower Huron units. This map was used together with shale matrix porosities to calculate the "free" and "sorbed gas content" for use in the simulator.

d. Fracture Spacing. The natural fracture spacing was determined by examining the number of joints per foot of shale interval, based on data in the cliffs study. The close match between the cliffs data and the fracture spacing established by the DOEMETC drilled deviated well (in Meigs County) gave confidence to this analytic approach for establishing fracture spacing. Spacing and direction of the micro-fault systems were al so identified for Ohio from the Cliffs data and are discussed later under fracture orientation.

The relative orientation of the natural fractures and the induced fractures is important, since they combine to provide the permeability conduit from which the sorbed and matrix gas will be produced. Cliffs placed major emphasis for their fracture directions on the induced fractures and prepared a series of maps and tables identifying the fracture directions in an attempt to indicate how production would be enhanced as a function of fracture orientation.

The core samples from the cliffs report give an accurate estimate of fracture spacing only for the area immediately around the core site. 
Exhibit 6

CALCULATED INDIGENOUS GAS CONTENT (MCF / Acre Foot)

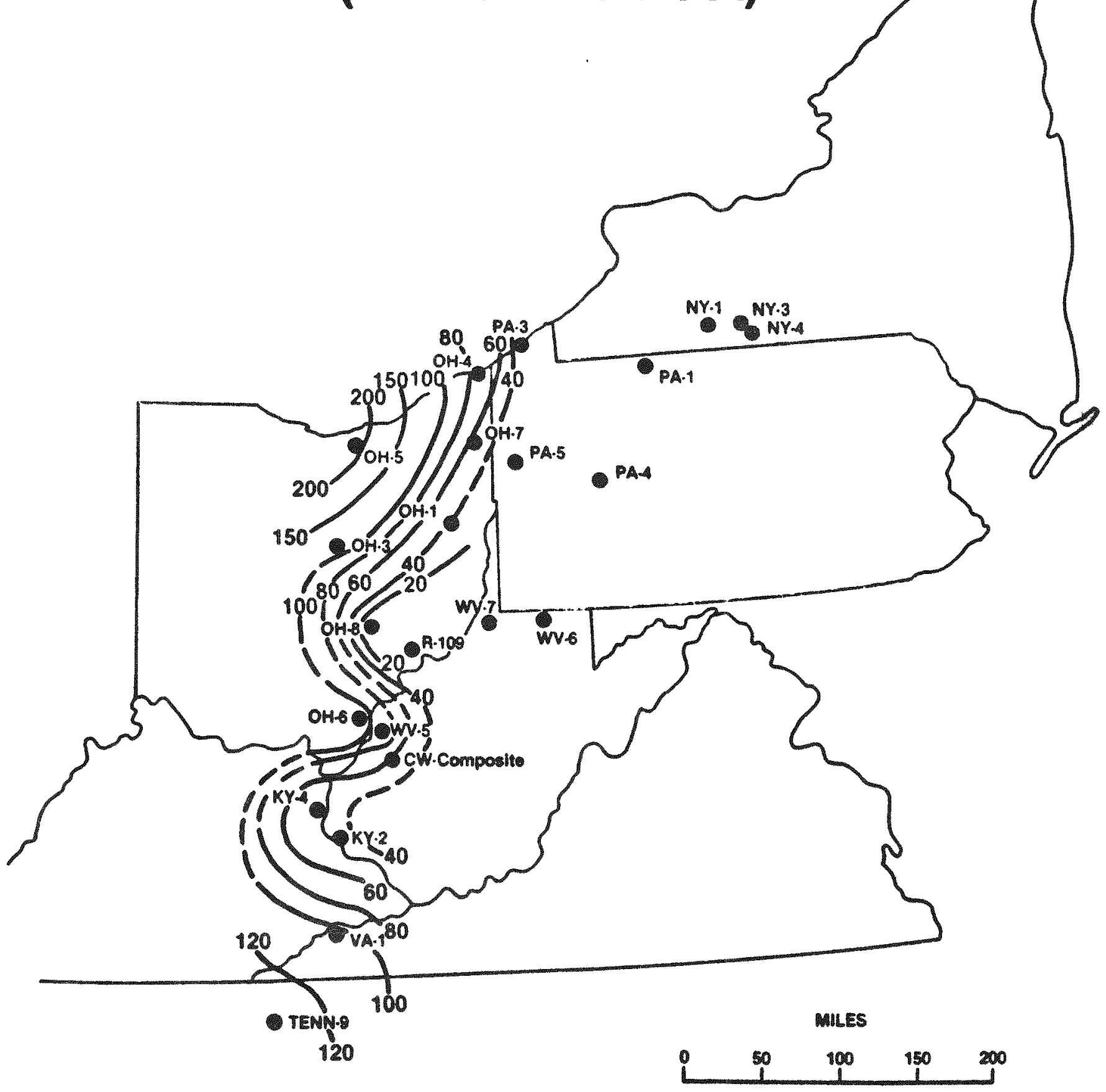

\section{LATE LOWER HURON/LATE DUNKIRK TIME Map Uni? 11}




\section{Exhibit 7}

LOWER AND MIDDLE HURON UNITS

\section{Gas Content (Mcf/AC-Ft.)}

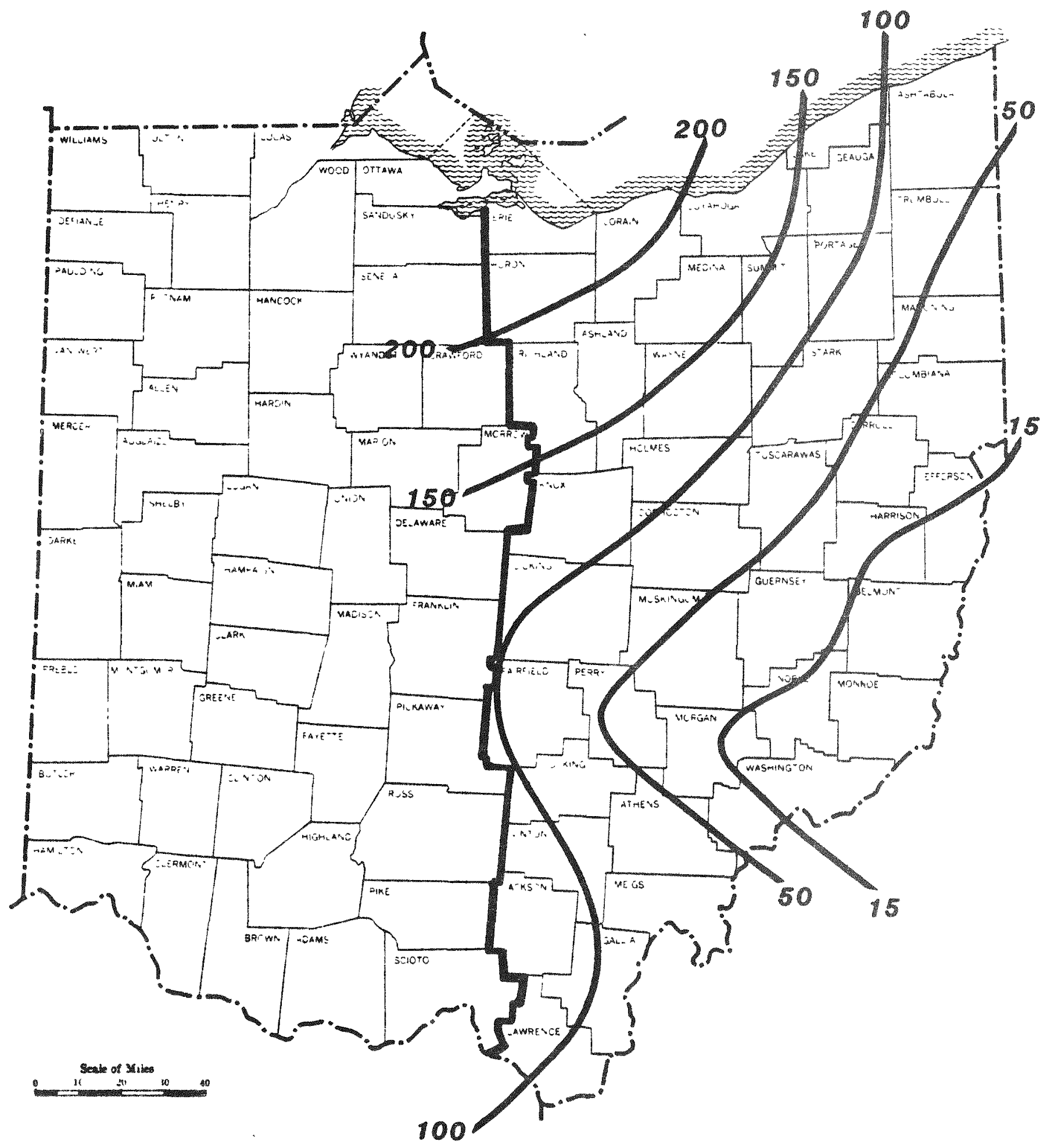


spacing in conjunction with the fracture data from the EGSP core wells. The fracture spacing is shown in Exhibit 8.

e. Fracture Permeability. Natural fracture permeability was estimated for each county in Ohio using analysis developed by Terra Tek and presented by Horton. 9

Assuming parallel natural fractures and accepting that some adjustment between laboratory and field results might be necessary, the following relationship was used for the determination of bulk natural fracture system permeability.

$$
k_{f}=\frac{\left(k_{f}^{\prime} \cdot w_{f}\right) c}{S}
$$

Where:

$$
\begin{aligned}
& k_{f}^{\prime}=\text { intrinsic fracture permeability, md } \\
& w_{f}=\text { fracture width, } c m \\
& s=\text { fracture spacing, cin } \\
& k_{f}=\text { bulk fracture system permeability, md } \\
& c \quad=\text { calibration constant, dimensionless }
\end{aligned}
$$

The Terra Tek data provided values of $\left(k_{f}^{\prime}, w_{f}\right)$ as a function of closure pressure in psi. Assuming vertical natural fractures and using predetermined values of Stress Ratio (SR) defined by:

$$
\begin{aligned}
& S R=\frac{\text { minimum horizontal stress }}{\text { vertical stress }} \\
& S R=\frac{\left(0_{H}\right)_{\text {min }}}{T .15 \mathrm{D}}
\end{aligned}
$$




\section{Exhibit 8}

\section{NATURAL FRACTURE SPACING (feet)}

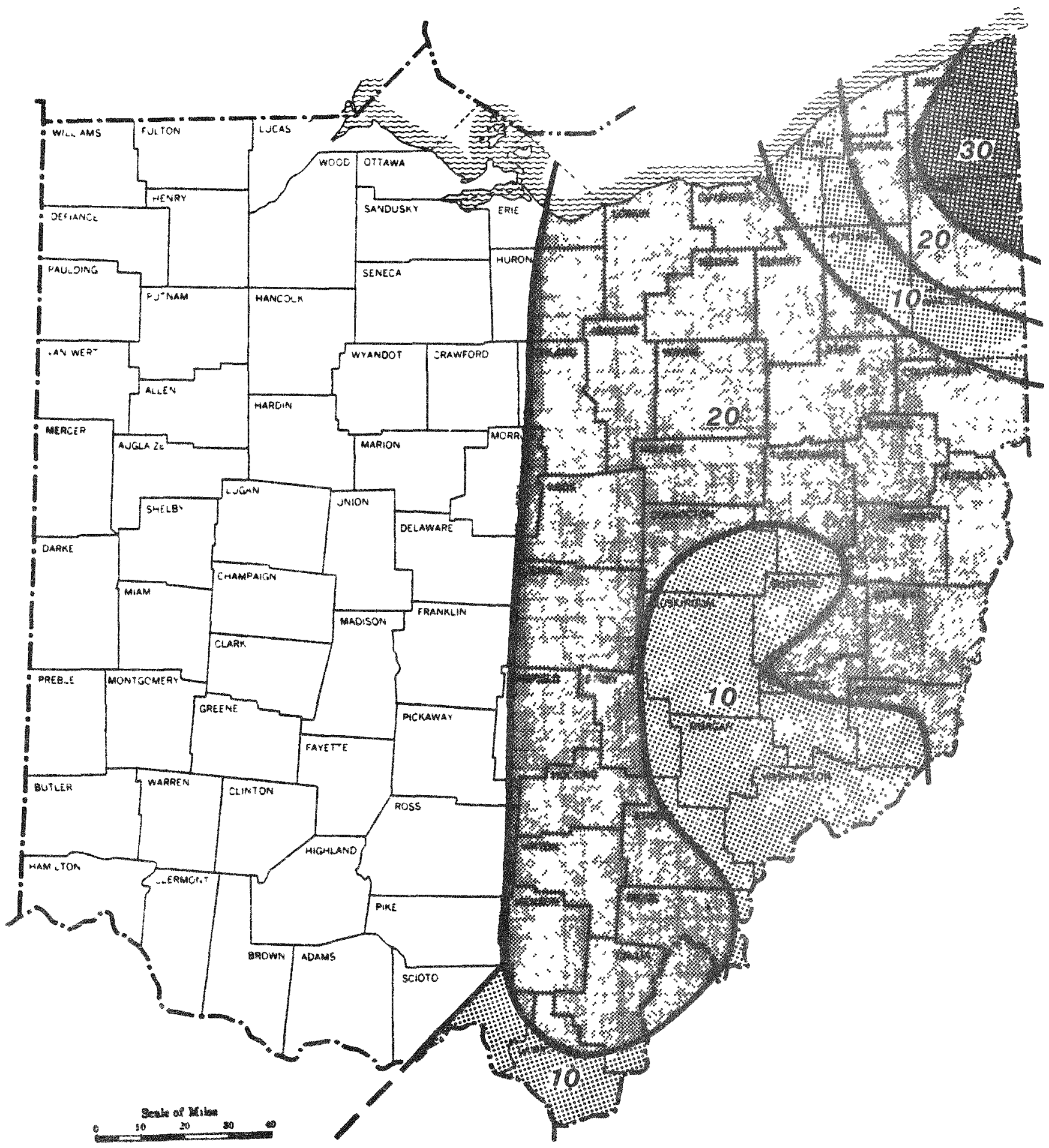


where:

$$
D=\text { depth, in feet }
$$

provided a means of obtaining closure pressure (CP) over the area of interest in onio. That is:

$$
\left(\sigma_{H}\right)_{\min }=C P=1.15 \mathrm{D}(S R)
$$

Thus, using the known stress ratio and shale depth for a given county, closure pressure, and hence the conductivity of a single natural fracture $\left(k_{f}^{\prime} \cdot w_{f}\right)$ could be determined.

Natural fracture spacing, $S$, was determined over Eastern Ohio from analysis of a variety of information compiled by DOE. The calibration constant, $C$, was determined fram the results of the offset Well Test Program (OWTP) and core observations from a subsequentiy deviated well drilled near the test site. Using a calculated closure pressure of $1,560 \mathrm{psi}$ in the Meigs County Well 10056, a value of 41 is derived for the product $\left(k_{f}^{\prime}\right.$. Wf $)$ from the Terra Tek fracture conductivity curve. With a buik fracture system permeability $\left(k_{f}\right)$ of $.07 \mathrm{md}$, determined from the OWTP and an observed naturai fracture spacing of approximately 20 feet $(610 \mathrm{~cm})$ in the nearby deviated wel1, a calibration constant of 1.04 was determined. Within experimental error, this may be taken as unity. Thus, using independentiy determined values of fracture spacing, natural fracture system permeability could be estimated as a function of shale depth for each study area, using the Terra Tek curve (Exhibit 9) directiy.

f. Productive Thickness. Using the reservoir properties described above, the SUGAR simulator was used to history match production data to determine the remaining reservoir property, "net productive thickness".

When available, long-term production data were used for the history match. Representative wells were identified for those counties (Lawrence, 
Exhibit 9

\section{EFFECT OF PROPPANTS ON CONDUCTIVITY}

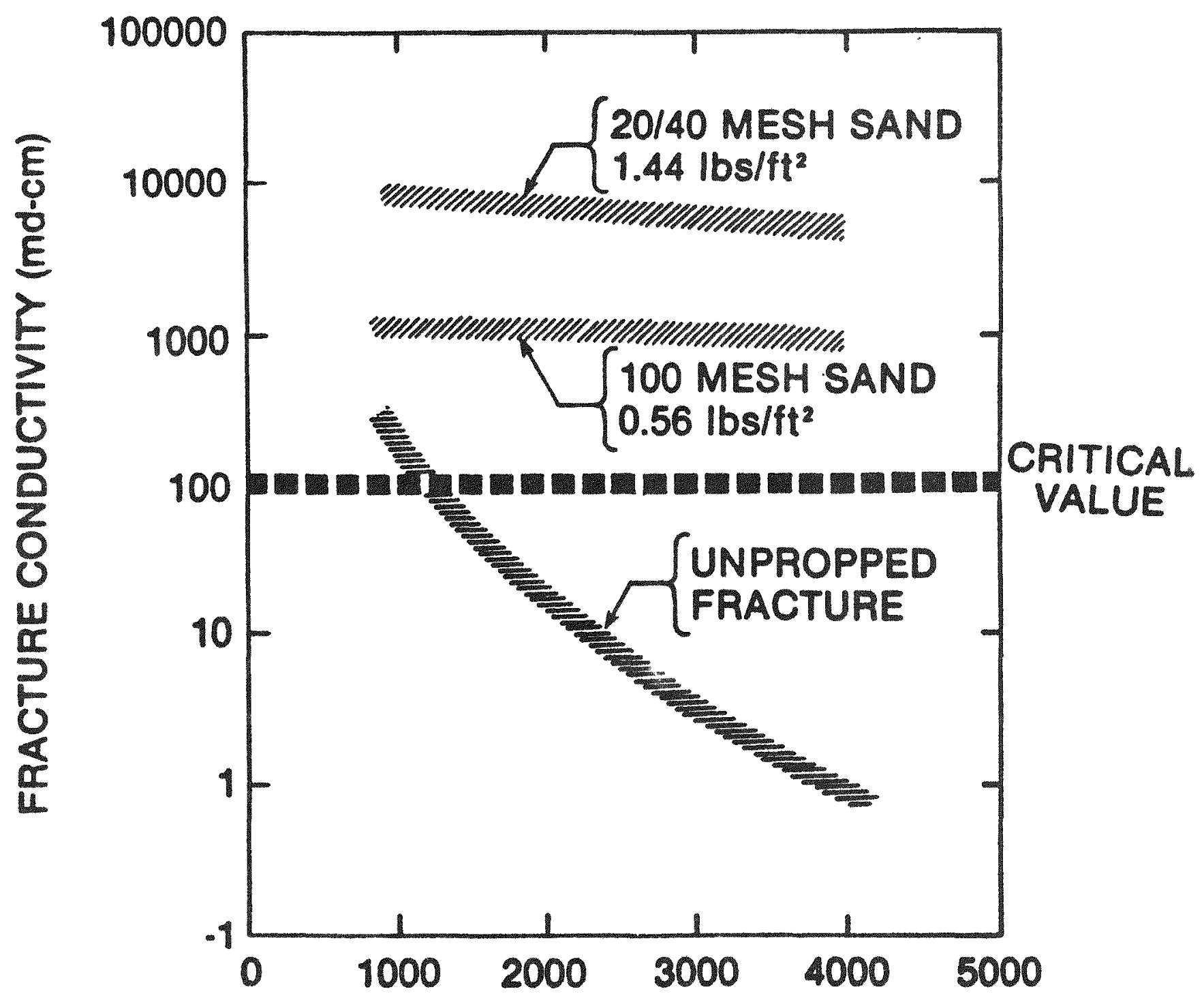

CLOSURE PRESSURE (pSI) 
Licking, and Meigs) where sufficient production data were available to characterize the resource in a statistically meaningful way. In selecting representative wells, the data base was screened to identify wells: (1) that were individually metered; (2) that had production from shale members distinguishable from other, non-shale producing horizons; (3) that included high, average, and low producers, and (4) had at least four years of production data. A detailed description of the selection of representative wells may be found in Appendix $C$.

When long-term production records were not available, initial open flow (IP) data and fracture permeability were utilized as part of a short-term history matching effort to arrive at productive thickness. While less confidence in results are provided by such an approach, the IP is directly proportional to the product of productive thickness and fracture permeability, and (when properly measured) gives a usable measure in absence of more stable data.

The history match of long-term production for Lawrence County is used as an example of this process, and is shown on Exhibit 10. Using the reservoir properties known for Lawrence County, the SUGAR model was employed with calculated fracture permeability to determine the net productive shale thickness that matched the initial gas flow rate as well as long-term gas production.

g. Final Data Set. A summary of the required data, their value ranges, and their sources are shown on Table 3. The table indicates three types of parameters: (1) constants, (2) variable by area, and (3) history matching. The majority of the constant data were obtained from the OWTP and EGSP core we11s, while the 1 arge portion of the variable data was derived from the Mound and Cliffs Minerals reports. The reservoir data required to run the borehole shooting case is shown by county in Table 4. 


\section{Exhibit 10}

HISTORY MATCH --

REPRESENTATIVE LAWRENCE COUNTY WELL

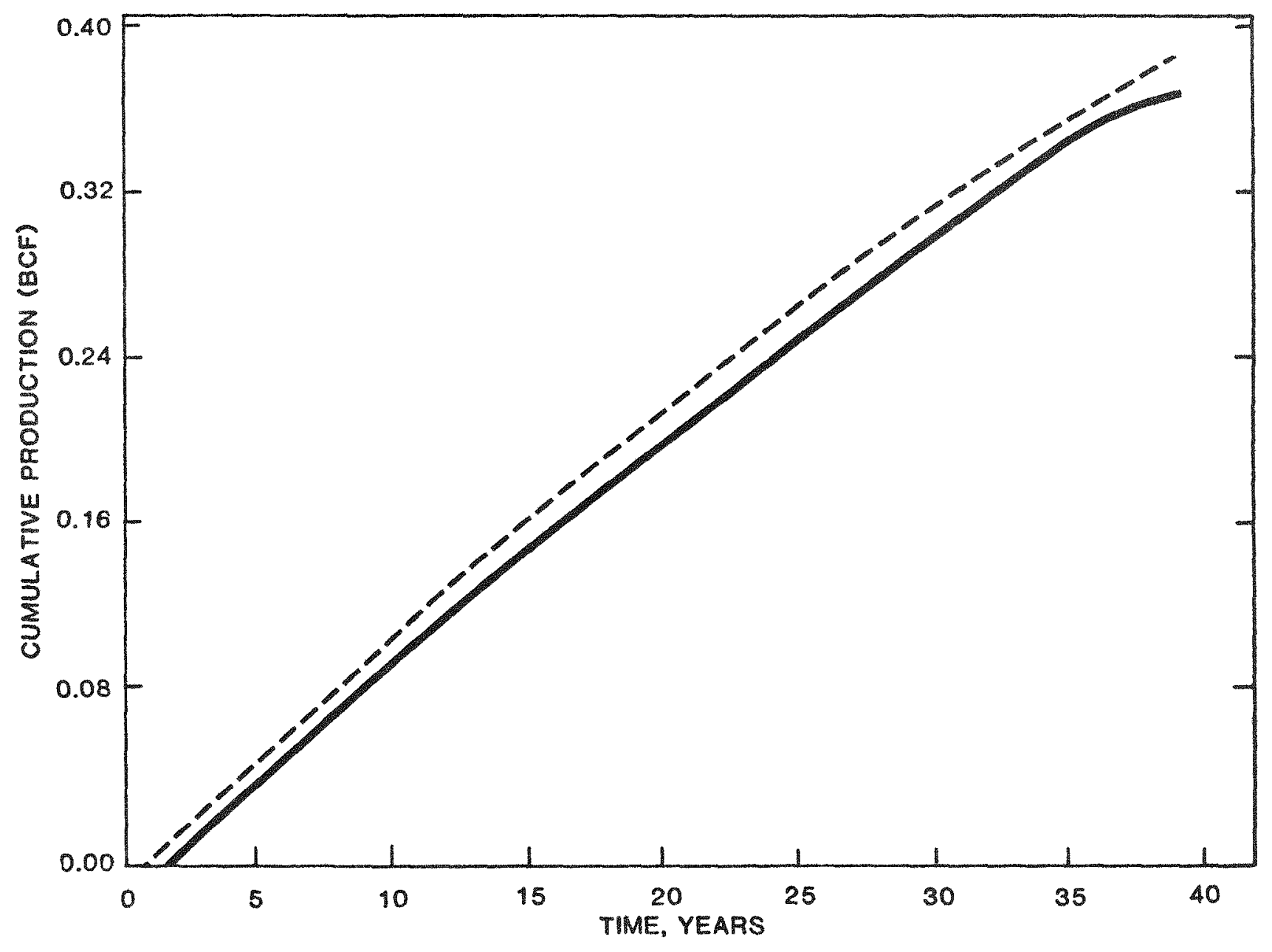


TABLE 3

REQUIRED RESERVOIR PAR AMETERS

\begin{tabular}{|c|c|c|}
\hline A. Constants & $\begin{array}{l}\text { Representative } \\
\text { Value or Range }\end{array}$ & Source \\
\hline Drainage Area, A & 160 Acres & Historical Production \\
\hline Matrix Permeability, $k_{m}$ & $5 \times 10-6 \mathrm{md}$ & Core Analysis \& Simulation \\
\hline Matrix Porosity, $\mathbb{m}_{m}$ & 0.01 & $\begin{array}{l}\text { Offset Well Test; Core } \\
\text { Analysis }\end{array}$ \\
\hline Fracture Porosity, $\Phi f$ & 0.0009 & Offset Well Test \\
\hline \multicolumn{3}{|l|}{ B. Variables, By Area } \\
\hline Fracture Permeability, $k_{f}$ & $0.02-4 \mathrm{md}$ & $\begin{array}{l}\text { Laboratory Tests (Terra } \\
\text { Tek); Stress Ratio (DOEMETC) }\end{array}$ \\
\hline Gas Content, $G_{C}$ & $10-220 \mathrm{Mcf} / \mathrm{AF}$ & Mound Report \\
\hline Initial Pressure, $P_{i}$ & $65-815$ psia & We 11 Records \\
\hline Line Pressure, $P_{1}$ & $25-100$ psia & Estimated \\
\hline Fracture Spacing, a & $10-30$ feet & $\begin{array}{l}\text { Cliffs Minerals Report; } \\
\text { Stress-Ratio Map }\end{array}$ \\
\hline C. Matching Parameters & & \\
\hline
\end{tabular}


TABLE 4

RESERVOIR PROPERTIES FOR OHIO COUNTIES

\begin{tabular}{|c|c|c|c|c|c|c|}
\hline County & $\frac{\text { Depth }}{\text { (feet) }}$ & $\frac{\text { Temp }}{\text { TFO }}$ & $\frac{\text { Pressure }}{\text { (psia) }}$ & $\begin{array}{l}\text { Frac } \\
\text { Spac } \\
\text { (feet) }\end{array}$ & $\frac{G C}{\text { TMCFTAFT }}$ & $\begin{array}{l}\text { Matrix } \\
\text { Perm. } \\
\text { (kf) }\end{array}$ \\
\hline $\begin{array}{l}\text { Ashland } \\
\text { Ashtabula } \\
\text { Athens } \\
\text { Belmont } \\
\text { Carroll }\end{array}$ & $\begin{array}{l}1315 \\
1365 \\
2465 \\
4210 \\
3145\end{array}$ & $\begin{array}{r}67.1 \\
67.7 \\
82.0 \\
104.7 \\
90.9\end{array}$ & $\begin{array}{r}215 \\
85 \\
615 \\
765 \\
540\end{array}$ & $\begin{array}{l}20 \\
30 \\
20 \\
20 \\
20\end{array}$ & $\begin{array}{r}175 \\
60 \\
60 \\
10 \\
35\end{array}$ & $\begin{array}{l}.2133 \\
.0200 \\
.0200 \\
.0200 \\
.0200\end{array}$ \\
\hline Columbiana & 3355 & 93.6 & 715 & 20 & 30 & .0200 \\
\hline Coshocton & 2135 & 77.8 & 390 & 10 & 70 & .4429 \\
\hline Cuyahoga & 1090 & 64.2 & 65 & 20 & 175 & .2789 \\
\hline Erie & 360 & 54.7 & 65 & 20 & 220 & 4.4291 \\
\hline Fairfield & 1180 & 65.4 & 290 & 20 & 90 & .2133 \\
\hline Gallia & 2460 & 82.0 & 715 & 20 & 700 & .0200 \\
\hline Ge auga & 1545 & 70.1 & 90 & 20 & 110 & .0591 \\
\hline Guernsey & 3560 & 96.3 & 525 & 20 & 20 & .0200 \\
\hline Harrison & 3410 & 94.3 & 640 & 20 & 15 & .0200 \\
\hline Hocking & 1605 & 70.9 & 415 & 20 & 85 & .0498 \\
\hline Holmes & 2050 & 76.7 & 340 & 20 & 100 & .0254 \\
\hline Huron & 365 & 54.7 & 90 & 20 & 200 & 4.4291 \\
\hline Jackson & 1515 & 69.7 & 470 & 20 & 50 & .0574 \\
\hline Jefferson & 3465 & 95.0 & 815 & 20 & 15 & .0200 \\
\hline Knox & 1315 & 67.1 & 290 & 20 & 110 & .2100 \\
\hline Lake & 1300 & 66.9 & 65 & 20 & 725 & .1247 \\
\hline Lawrence & 2320 & 80.2 & 690 & 10 & 100 & .0276 \\
\hline Licking & 1500 & 69.5 & 240 & 20 & 90 & .2993 \\
\hline Lorain & 960 & 62.5 & 73 & 20 & 200 & .5085 \\
\hline Mahoning & 2805 & 86.5 & 365 & 10 & 40 & .0200 \\
\hline Medina & 1490 & 69.4 & 95 & 20 & 770 & .0951 \\
\hline Meigs & 2740 & 85.6 & 775 & 20 & 80 & .0771 \\
\hline Monroe & 4715 & 111.3 & 765 & 10 & 5 & .0200 \\
\hline Morgan & 2990 & 88.9 & 615 & 10 & 15 & .0886 \\
\hline Muskingum & 2425 & 81.5 & 415 & 10 & 40 & .2362 \\
\hline Noble & 3755 & 98.8 & 735 & 10 & 15 & .0387 \\
\hline Perry & 1945 & 75.3 & 415 & 20 & 45 & .0213 \\
\hline Portage & 1995 & 75.9 & 140 & 10 & 95 & .0427 \\
\hline Richland & 1105 & 64.4 & 275 & 20 & 175 & .4921 \\
\hline Stark & 2120 & 77.6 & 315 & 20 & 80 & .0200 \\
\hline Sumit & 1725 & 72.4 & $\pi$ & 20 & 725 & .5020 \\
\hline Trumbul1 & 2135 & 77.8 & 135 & 20 & 50 & .0200 \\
\hline Tuscarawas & 2660 & 84.6 & 485 & 20 & 55 & .0200 \\
\hline Vinton & 1615 & 71.0 & 460 & 20 & 100 & .0476 \\
\hline Wa shing ton & 4515 & 108.7 & 815 & 10 & 70 & .0223 \\
\hline Wayne & 1660 & 71.6 & 215 & 20 & 140 & .0574 \\
\hline
\end{tabular}




\section{DEVELOPMENT OF REPRESENTATIVE DATA FOR EACH REGION}

The parameters required for the stimulation cases, beyond those required for the borehole shooting case, include:

- Fracture permeability expressed in $x-a n d-y$ components to reflect permeability anisotropy;

- Angle of intersection between the induced and natural fractures;

- Pressure gradients in the stimulation geometry; and,

- Drainage pattern shape.

The se were determined for each of the six partitioned areas of ohio. The rationale for partitioning is discussed in the following chapter.

1. Horizontal Stress

Horizontal stress was used here to indicate the preferred orientation direction of induced fractures. In-situ stress field components were determined and mapped based on data by $\mathrm{Cl}$ iffs Minerals. Stress from a shallow well test and stress from a surface test were plotted. The resulting map provided results of in-situ stress measurements made in the basin and indicate maximum horizontal stress. The Cliffs' work on stress measurements were reviewed and generalized directional trends were plotted for Ohio, as shown in Exhibit 11.

\section{Natural Fracture Orientation}

The fracture orientations were mapped using fracture logs compiled by Cliffs Minerals. The log records indicate the strike and dip for each natural fracture. All EGSP core wells located in Ohio, which were included 
Exhibit 11

\section{HORIZONTAL STRESS TRAJECTORIES}
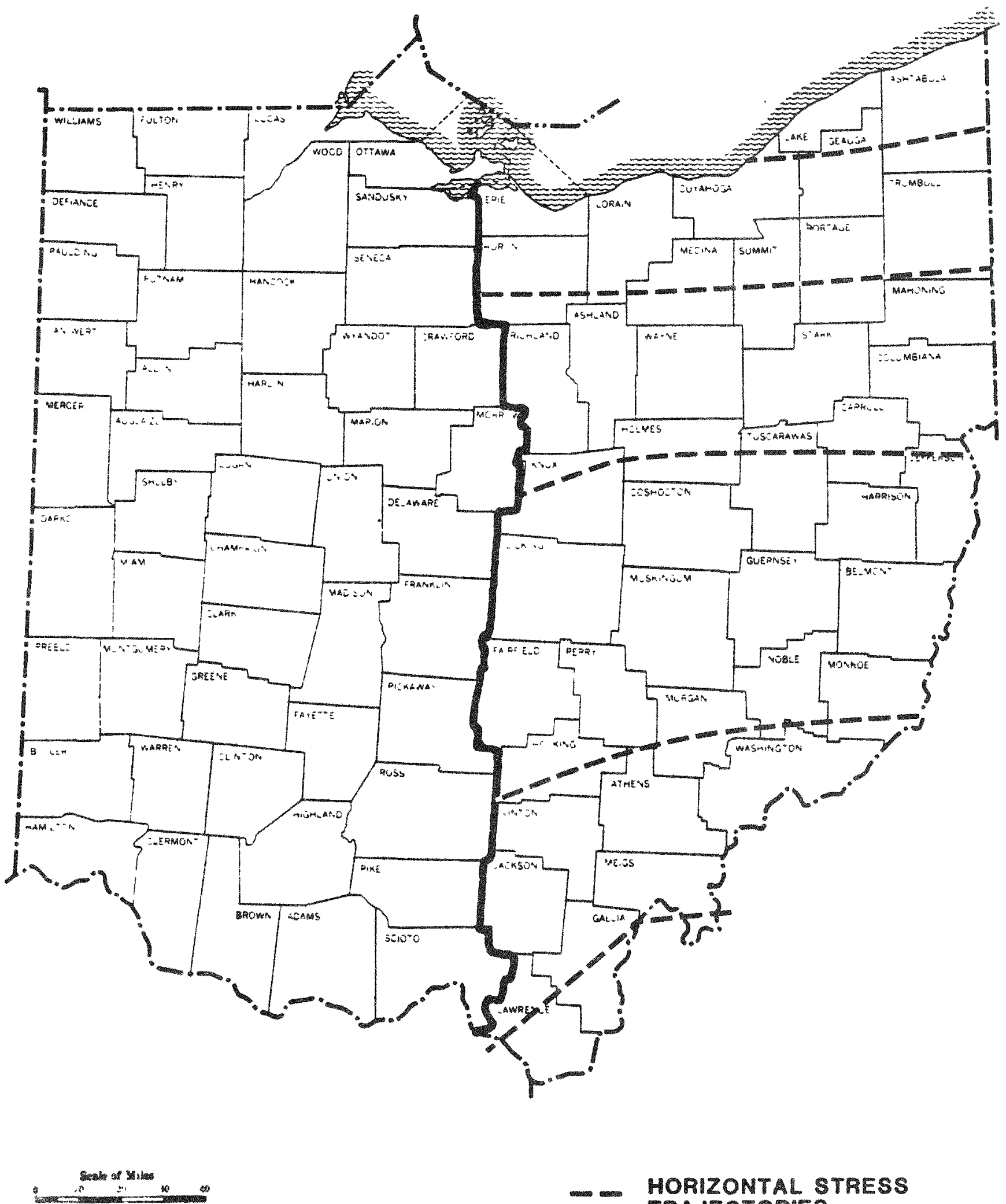
Exhibit 12

\section{REGIONAL ORIENTATIONS \\ NATURAL VS. INDUCED FRACTURES}

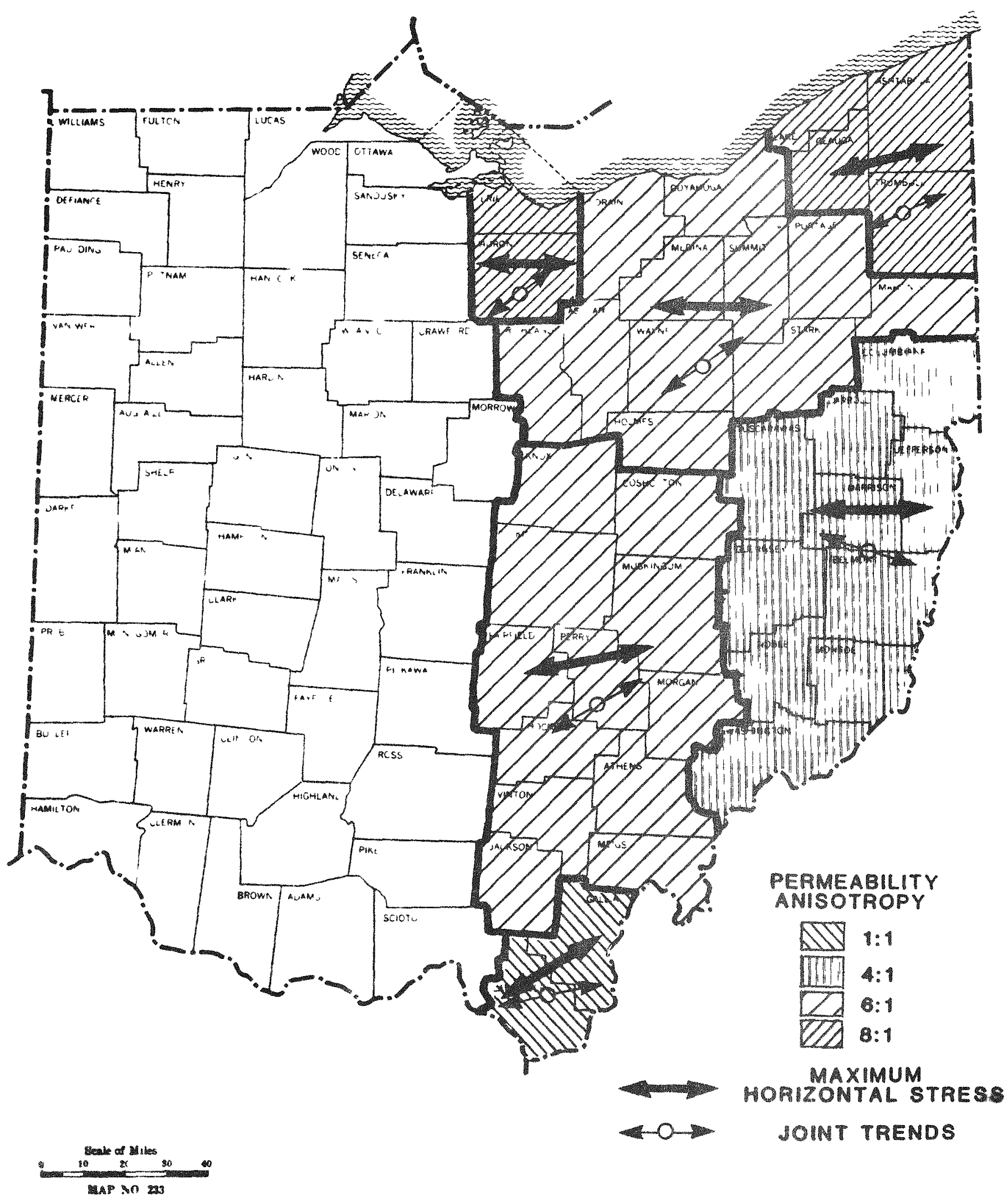


in the cliffs report series, were considered. The log records were reviewed and the strike and dip were tabulated per natural fracture with in a specific Devonian shale member. The tabulated results allowed identification and labeling of the major and minor natural fracture direction. The resulting directions were mapped and are shown in Exhibit 12. The angle between the induced and natural fractures was determined by area and is shown below:

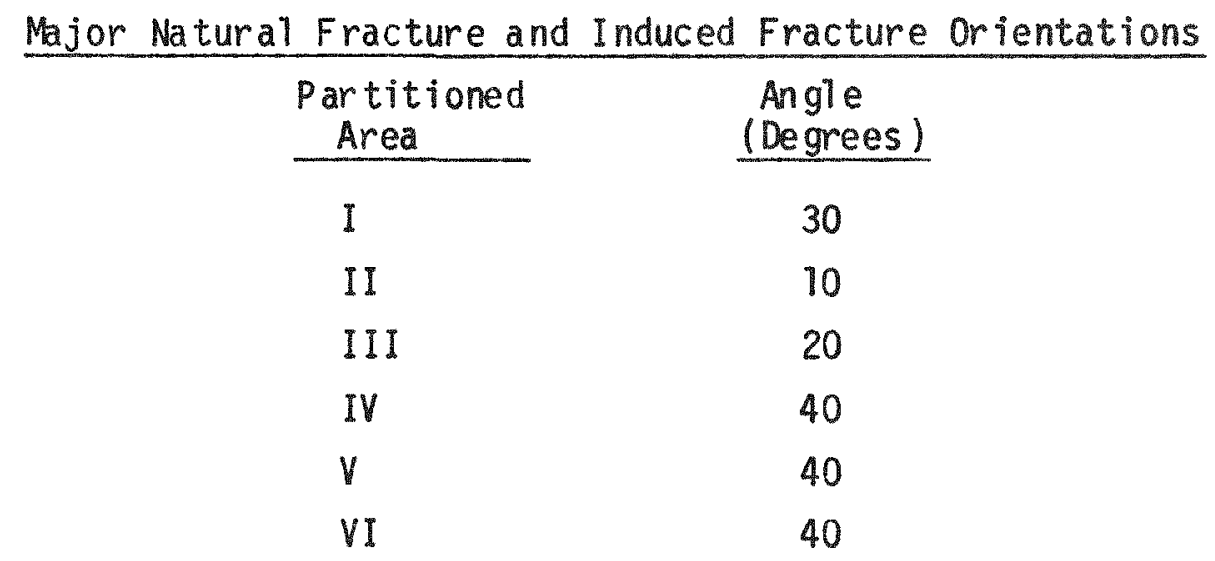

3. Permeability Ani sotropy

Permeability anisotropy was determined for each partition area from the relative intensity of the major and minor natural fractures. Thus, a ratio of the major and minor natural fractures was identified.

\begin{tabular}{|c|c|}
\hline $\begin{array}{c}\text { Partitioned } \\
\text { Area }\end{array}$ & $\begin{array}{c}\text { Ratio } \\
\left(k_{x}: k_{y}\right)\end{array}$ \\
\hline $\begin{array}{l}\text { I } \\
\text { II } \\
\text { III } \\
\text { IV } \\
\text { V } \\
\text { VI }\end{array}$ & $\begin{array}{l}1: 1 \\
6: 1 \\
4: 1 \\
6: 1 \\
8: 1 \\
8: 1\end{array}$ \\
\hline
\end{tabular}

The permeability in the $x$ and $y$ directions was then calculated for input into the SUGAR Simulator. 
4. Reservoir Properties by Area

The data aggregated from the data compilations and analyses are summarized on Table 5, as follows:

\section{TABLE 5}

AVERAGE GEOLOGIC PROPERTIES BY AREA

$\begin{array}{lccc}\begin{array}{l}\text { Parti- } \\ \text { tioned }\end{array} & \begin{array}{c}\text { Frac. } \\ \text { Area }\end{array} & \begin{array}{c}\text { Perm. } \\ \text { Aniso- } \\ \text { Spacing } \\ \text { tropy }\end{array} & \begin{array}{c}\text { Inter- } \\ \text { sect } \\ \text { Angle }\end{array} \\ \text { I } & 10 & 1: 1 & \text { (degrees) } \\ \text { II } & 20 & 6: 1 & 10 \\ \text { II } & 20 & 4: 1 & 20 \\ \text { IV } & 20 & 6: 1 & 40 \\ \text { V } & 20 & 8: 1 & 40 \\ \text { VI } & 20 & 8: 1 & 40\end{array}$




\section{PARTITIONING THE STATE}

The partitioning of Ohio considered both regional geology, tectonophysics and gas production trends. The tectonophysics of the region include detachment limits as well as fracture orientation and permeability geologic characteristics. The geologic characteristics were derived primarily from analyzing the $\mathrm{Cl}$ iffs Minerals study and included:

- Horizontal Stress (Exhibit 11)

- Permeability Anisotropy (Exhibit 12)

- Natural Fracture Orientation (Exhibit 13)

- Mechanical Fabric of the Shales (Exhibit 14)

These characteristics have been discussed in detail in the previous chapter. Along with the geologic characteristics, the projected average 40-year cumulative production estimate was used as a parameter in partitioning.

These factors were then analyzed using a trend surface analysis approach and the resulting partition of Ohio is shown in Exhibit 15. This form of analysis attempts to group counties with similar characteristics together, while minimizing the variation of a single characteristic within the group. Counties which exhibited regional geologic trends similar to two areas were included in the area where the gas production or rock pressure characteristics would cause the least variation within the group. 
Exhibit 13

\section{NATURAL FRACTURE ORIENTATION}
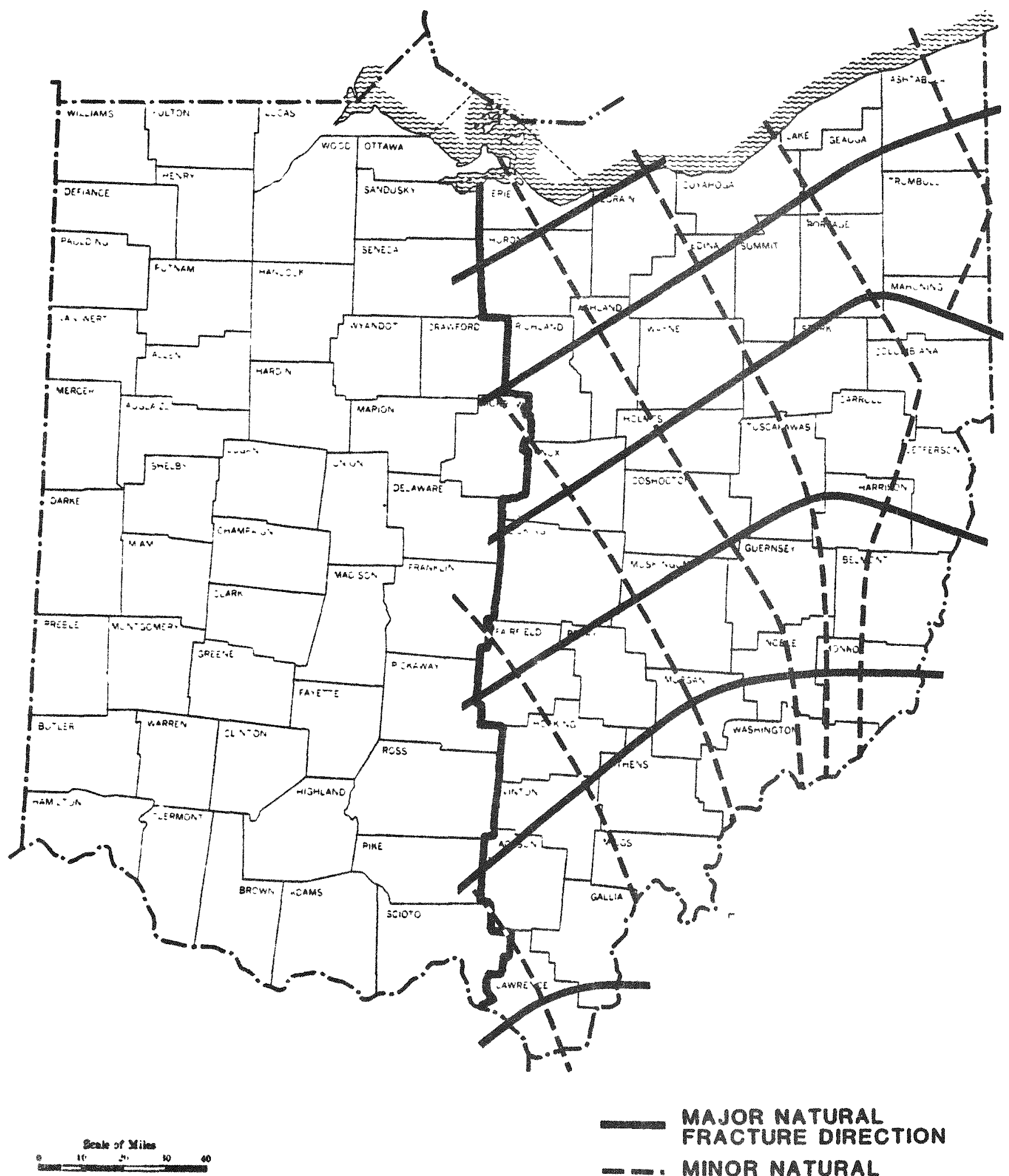

MAJOR MATURAL FRACTURE DIRECTION

- MINOR NATURAL

FRACTURE DIRECTION 
Exhibit 14

MECHANICAL FABRIC TREND IN SHALE

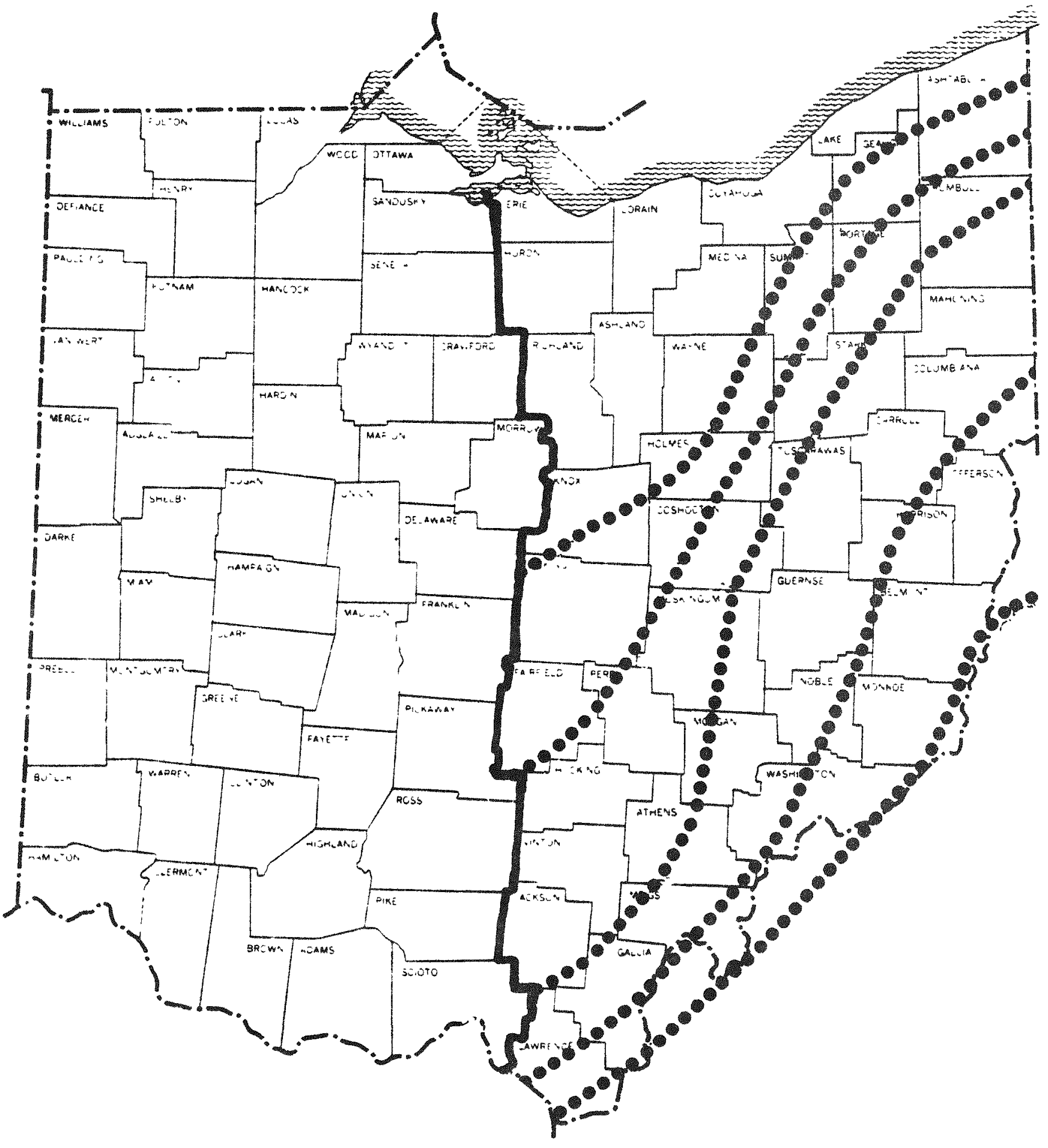




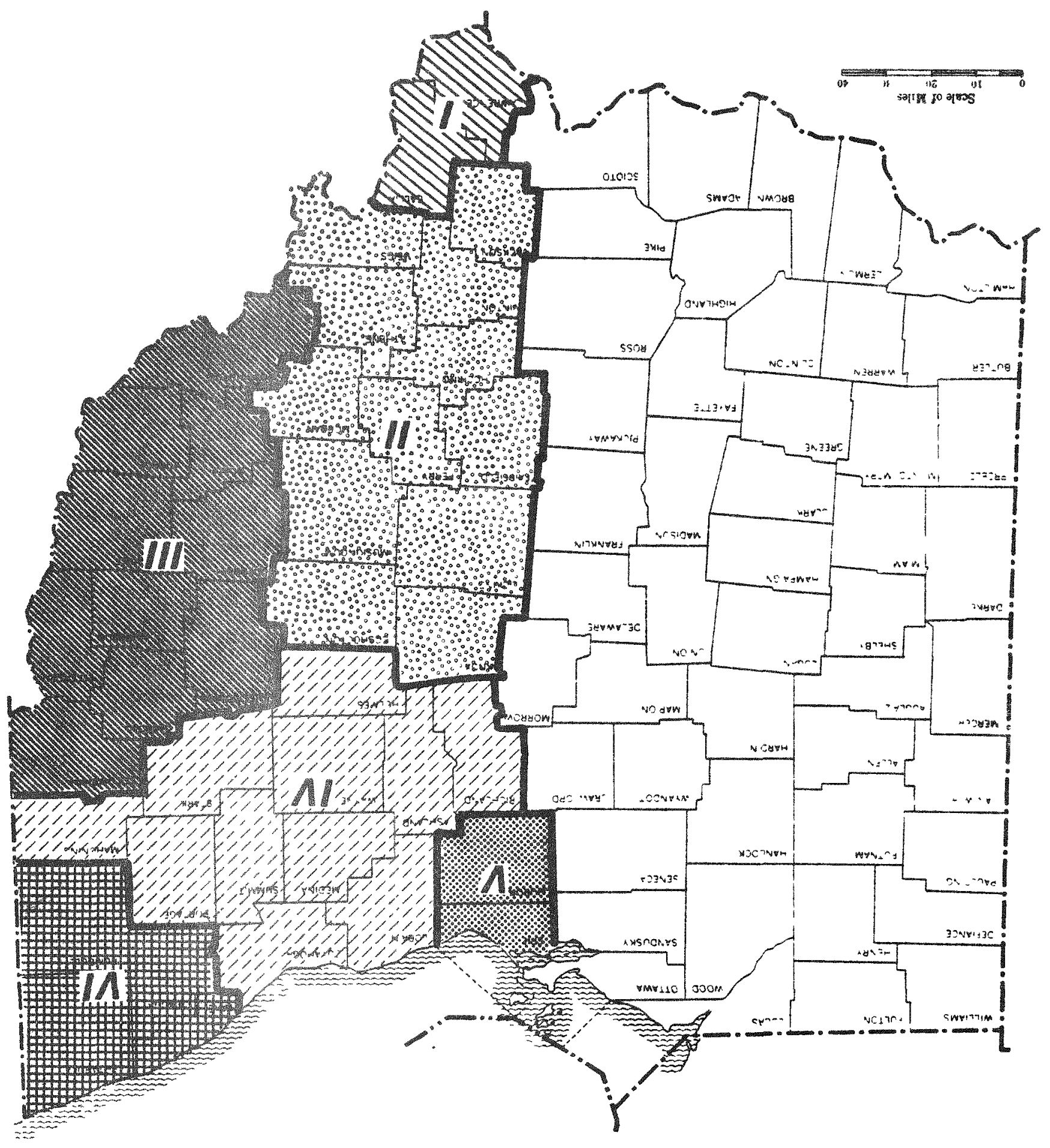

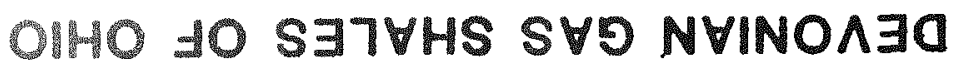

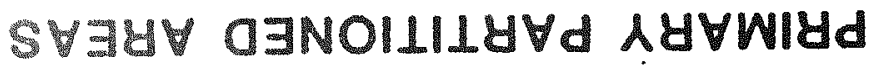

S! $1 ! 9 ! 4 \times \exists$ 
V. RESERVOIR MODELING AND WELL STIMULATION

This chapter describes the reservoir model used by the study, provides a brief review of the advanced well stimulation cases analyzed, and presents basic information on the procedures used to model the stimulation cases.

\section{A. SUGAR MODEL}

The model used for the history match is the two-dimensional numerical model (SUGAR-MD) available at DOE/METC. This model was developed specifically for analyzing Devonian Shale production and includes the three key sources for gas storage and production; namely:

- The macro-fracture system,

- The micro-fracture system, and

- Gas adsorbed on the organic kerogen in the shale.

The SUGAR model describes the transient pressure response of a naturally fractured reservoir by two dimensionless parameters: the dimensionless fracture storage coefficient, $\omega$, and the dimensioniess fracture transfer coefficient, $\lambda$. These are defined as follows:

- The dimensionless fracture storage coefficient, $\omega$, is defined as:

$$
\omega=\frac{\phi_{f}}{\phi_{f}+\phi_{m}}
$$

where: $\Phi_{f}=$ fracture porosity

$\Phi_{m}=$ matrix porosity 
- The dimensionless fracture transfer coefficient, $\lambda_{0}$ is defined as:

$$
\lambda=\frac{8}{a^{2}}\left[\frac{k_{m}}{k_{f} / r_{w}^{2}}\right]
$$

where: $2 a$ = fracture spacing

$$
\begin{aligned}
& k_{f}=\text { fracture permeability } \\
& k_{m}=\text { matrix permeability }
\end{aligned}
$$$$
r_{W}=\text { we11-bore radius }
$$

The two dimensionless parameters used by the SUGAR simulator establish a direct relationship between certain of the reservoir parameters. The dimensionless transfer coefficient, $\lambda$, determines the interdependence between $k_{m}, k_{f}$, and $r_{w}$. This means that unless two of these parameters are known with certainty, the third cannot be determined as an independent value from history matching. In addition, any uncertainty in the magnitude of one of the parameters will have a direct effect on the value of one or both of the other parameters.

In addition, there are two unconventional gas storage parameters:

$h$ = "net productive" interval

- $G_{C}=$ adsorbed gas content

The proper selection of values for these parameters can lead to a highly accurate history matching of actual gas production. 
B. DELINEATION OF STIMULATION CASES

Five well stimulation techniques were evaluated for their applicability to Ohio Devonian shales:

Borehole Shooting $\left(r^{\prime}{ }_{w}=1.8\right.$ feet $)$ : currently the most frequently used technique in the Devonian shales;

- Small Radial Stimulation $\left(r_{w}^{\prime}=30\right.$ feet $)$ : attainable with emerging technological improvements such as omni-directional stimulation;

- Large Radial Stimulation $\left(r^{\prime}{ }_{w}=60\right.$ feet $)$ potentially attainable with major improvements in explosive and propellant technology:

- Small Vertical Fracture $\left(x_{f}=150\right.$ feet $)$ : attainable, but not yet fully controllable or predictable with current technology; and

- Large Vertical Fracture $\left(x_{f}=600\right.$ feet): potentially attainable with significant advances in technology or alternate fracture fluids and proppants.

A schematic of radial and vertical stimulation techniques appears in Exhibit 16. 
Exhibit 16

\section{STIMULATION TREATMENT SCHEMATICS}

RADIAL STIMULATION SCHEMATIC

(Not to Scale)

160 Acres

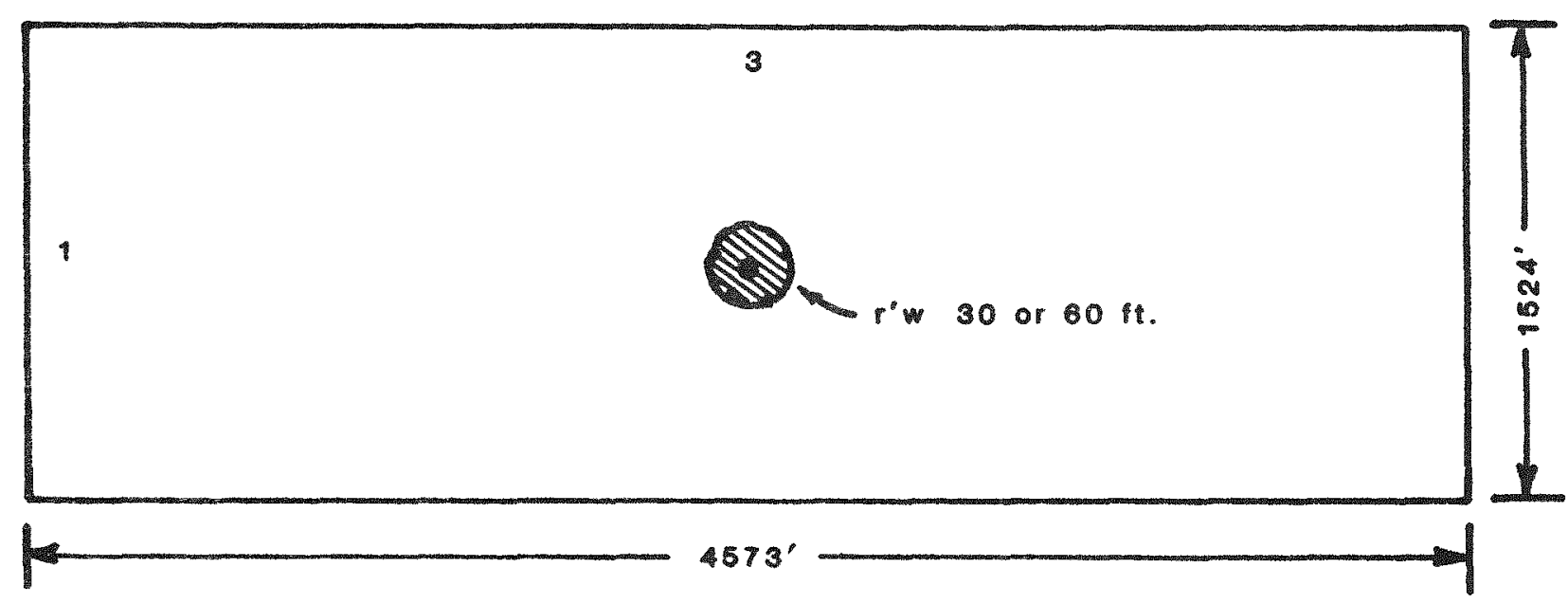

INDUCED FRACTURE SCHEMATIC (Not to scale)

160 Acres

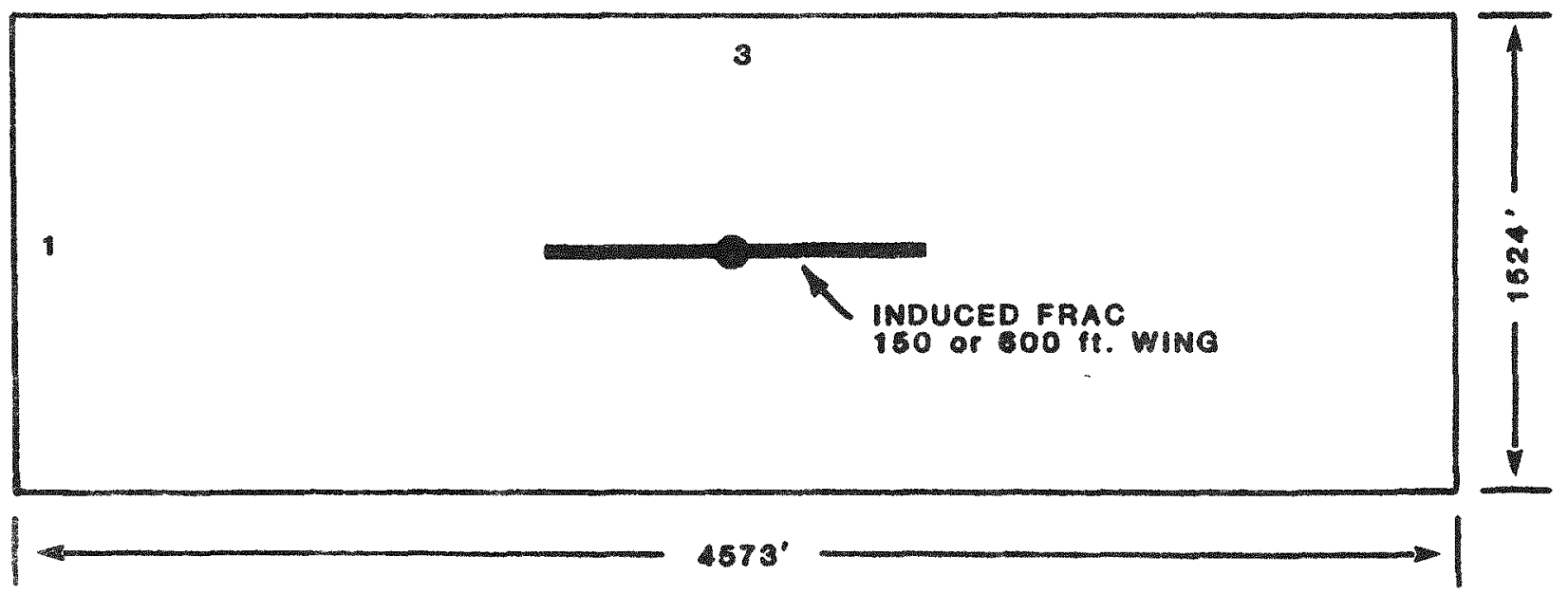




\section{MODELING OF STIMULATION CASES}

Each of the stimulation cases requires an $x-y$ grid-block layout in the SUGAR Simulator to accommodate the radial or induced fracture design.

The variable pressure blocks which drive the radial stimulation cases are a function of line pressure and well depth. The fracture geometry for the radial stimulations was designed for effective wellbore radi i of 30 and 60 feet, with line pressure applied out to the radius of the stimulation in both radial cases, which therefore assumes infinite conductivity from the wellbore to the tip of the radius. In the vertical fracture cases, the fracture is assumed to have infinite conductivity along the length of the wing and the line pressure is applied along the entire distance.

To properly model induced vertical fractures, variable rate blocks must be specified. The rate blocks are a function of 1 ine pressure, productivity index, and well depth. The productivity index in turn is dependent on the following factors:

- Brock size in the direction of the induced fracture,

- Block size in the direction perpendicular to the induced fracture,

- Fracture permeability in the direction perpendicular to the induced fracture, and

- Productive shale thickness. 
VI. TECHNICALLY RECOVERABLE GAS

\section{A. SUMMARY}

The Devonian shales of Ohio (Lower Huron member) offer an important future source of natural gas. The target intervals analyzed by this study contain an estimated 50 Tcf of gas in-place. Recent research shows that a major portion of this gas may be feasible to recover, as discussed below:

- Total gas in-place in the Devonian shales of Ohio is large, amounting to nearly 390 Tcf. The Huron interval accounts for approximately two thirds of this total, or over 250 Tcf. The selected portions of Middle and Lower Huron members, the vertical sequence historically completed in the ohio shales, and the target interval for this study, contain nearly 50 Tcf.

- The technically recoverable gas from the target sequence of Devonian shales of ohio ranges from 6.2 to 22.5 Tcf. The low end of the range reflects well stimulation by borehole shooting and current field development practices. The high end of the range reflects application of advanced stimulation technology (vertical fracturing and radial stimulation and use of alternative field development methods.

- Gas recovery and flow rates per well vary widely, with highest recoveries in southern ohio. Highest gas production rates and ultimate recovery can be expected in southern onio (Area I). Gas recoveries per well can reach 1,000 MMcf (40 year cumulative recovery with large, 600-foot half length, vertical fractures) with gas flow rates of 200 Mcf per day (daily average for first four years). Lowest recovery and gas flow rates are in northeast onio (Area VI). Here ultimate recovery is estimated at 24 MMcf (40-year cumulative recovery with 60-foot radial stimulation) with gas flow rates of 2 Mcf per day. 
- It will take a major drilling effort, from 44 to 88 thousand wells, to produce the technically recoverable gas in Ohio. Given an undrilled, accessible area of nearly 11,000 square miles lover 7 million acres), it would take 43,970 wells on 160-acre spacing, or 87,940 wells on 80 -acre spacing, to fully develop and produce the technically recoverable gas in the Devonian shales (Lower Huron memberl of Ohio.

- Improved stimulation technology is required to unlock the full gas potential. Use of large vertical fractures, in the high gas potential Area I, will provide per well cumulative recoveries (over 40 years) of 1,080 MMCf versus 386 MMcf by borehole shooting. Even in the low gas potential Area VI, large radial stimulation would more than double the gas flow rates and ultimate recovery as compared with borehole shooting. Future technical advances for more efficiently interconnecting the natural fracture system to the well drainage area would further add to gas recovery.

- Alternative well spacing and pattern configuration will also help increase gas recovery. Reduced well spacing, to 80 acres per well, will substantially increase gas recovery--from 15.2 Tcf at 160 acres to 22.5 Tcf at 80 acres-without appreciably reducing recovery in the initial years. In addition, changing the pattern alignment to a 3 by 1 rectangle from the traditional square pattern improves gas recovery per well by 5 to 10 percent.

These findings are further discussed in the following sections and assume that prudent drilling and completion practices will be adhered to and that the wells are properiy sited. 
B. GAS IN-PLACE

Total gas in-place in the Devonian shales of ohio is 1 arge, amounting to nearly 390 TCf. Of this total, the Huron interval accounts for approximately $250 \mathrm{Tcf}$. The net productive interval or "target interval" in the Middle and Lower Huron units contain nearly 50 Tcf in the six partitioned areas of Ohio, with Area IV alone containing 25 Tcf. The target interval is composed of the vertical shale sequence, which was determined to be productive through simulation with the SUGAR model. Gas in-place is shown by partitioned area and interval below:

$\frac{\text { TABLE } 6}{\text { TOTAL GAS IN-PLACE }}$

Partitioned Area

$$
\begin{aligned}
& \text { Gas In-Place } \\
& \text { All Intervals } \\
& \text { (Tcf) }
\end{aligned}
$$

Gas In-P1 ace

Gas In-Place

Area

$\frac{\text { Huron Interval }}{\text { (TCf) }}$

Target Interval

$\begin{array}{rrrr}\text { I } & 16.0 & 13.0 & 4.1 \\ \text { II } & 106.4 & 78.9 & 12.4 \\ \text { III } & 119.2 & 53.1 & 4.4 \\ \text { IV } & 101.4 & 78.1 & 24.8 \\ \text { V } & 9.0 & 8.6 & 0.4 \\ \text { VI } & 36.9 & 21.8 & 3.3 \\ \text { TOTAL } & 388.9 & 253.5 & 49.4\end{array}$

The gas in-place is contained in three sources:

- Free matrix gas is that gas which fills small micro-fractures and other smail matrix porosities;

- Sorbed matrix gas is that gas absorbed or adsorbed by the organic matter in the shale; and,

- Free fracture gas is that gas filling the major fractures and joint systems. 
The gas content data determined by Mound were used in this study to calculate the free matrix and sorbed matrix gas contents. The Mound data contain the total gas content in the matrix and were provided in Mcf/acre-foot. To calculate the free matrix portion of the gas, the following equation was used:

$$
G_{C}=\frac{-35.37}{T} \cdot \Phi \mathrm{m} \cdot \frac{P_{i}}{Z_{i}}
$$

where: $G_{C}=$ Gas Content (Mcf/AF)

$T=$ Reservoir temperature $\left({ }^{\circ} R\right)$

$\Phi_{m}=$ Matrix porosity (decimal)

$P_{i}=$ Initial rock pressure $(p s i a)$

$z_{i}=Z$ factor

Once the free matrix gas has been calculated, the sorbed matrix gas may be calculated as the difference between the Mound number and the free matrix gas. The free fracture gas is determined assuming complete gas saturation in the fractures.

The major portion of the gas is from the sorbed matrix portion in all areas of Ohio except Area III, where the gas content is extremely low. The percentage of gas by source has been compiled in Table 7 . 
TABLE 7

GAS IN-PLACE BY GAS SOURCE, FOR HURON TARGET INTERVAL

\begin{tabular}{cccc} 
& \multicolumn{3}{c}{ GAS IN-PLACE } \\
\cline { 2 - 4 } $\begin{array}{c}\text { Partitioned } \\
\text { Area }\end{array}$ & $\begin{array}{c}\text { Free } \\
\text { Fracture }\end{array}$ & $\begin{array}{c}\text { Free } \\
\text { Matrix }\end{array}$ & $\begin{array}{c}\text { Sorbed } \\
\text { Matrix }\end{array}$ \\
\hline I & 2 & $\frac{(\%)}{(\%)}$ & $\frac{75}{(\%)}$ \\
II & 1 & 23 & 91 \\
III & 7 & 8 & 18 \\
IV & $*$ & 75 & 95 \\
V & $*$ & 5 & 98 \\
VI & 1 & 1 & 91 \\
OVERALL & 1 & $\frac{8}{85}$
\end{tabular}

GAS IN-PLACE

(TCf, By Area)

Partitioned

Area

Free

$\frac{\text { Fracture }}{\text { (Tcf) }} \frac{\text { Matrix }}{\text { (Tcf) }}$

Sorbed

Matrix Total

T(Tf) TTCf)

I

0.1

1.0

3.0

4.1

II

0.1

1.0

11.3

12.4

III

0.3

3.3

0.8

4.4

IV

0.1

1.1

23.6

24.8

$V$

**

0.4

0.4

VI

$\pm *$

3.0

3.3

TOTAL AREA

0.6

6.7

42.1

49.4

* Less than $0.5 \%$

*Less than 0.05 Tcf 
C. DISCUSSION OF RECOVERABLE GAS AND RECOVERY EFFICIENCY

Recoverabie gas in Ohio ranges from 6.2 to 15.2 TCf in 40 years, for wells drilled on 160-acre spacing, as shown on Table 7, below. Drilling on an 80-acre spacing could increase recoverable gas to 22.5 Tcf over 40 years. (The potential for alternative well spacing is further discussed in Chapter VII, Other Factors Af fecting Production.)

TABLE 8

TECHNICALLY RECOVERABLE GAS, BY AREA

AND STIMULATION METHOD

\begin{tabular}{|c|c|c|c|c|c|c|c|}
\hline \multirow[b]{2}{*}{$\begin{array}{l}\text { Parti- } \\
\text { tioned } \\
\text { Area } \\
\end{array}$} & \multirow[b]{2}{*}{$\begin{array}{c}\text { Total } \\
\text { Drillable } \\
\text { Area } \\
\text { (Sq. Mi.) }\end{array}$} & \multirow[b]{2}{*}{$\begin{array}{l}\text { Gas In- } \\
\text { Place } \\
\text { TTcf }\end{array}$} & \multicolumn{5}{|c|}{ Technically Recoverable Gas (Tcf) in 40 Years } \\
\hline & & & $\begin{array}{l}\text { Borehole } \\
\text { Shooting }\end{array}$ & $\begin{array}{c}\text { Smalt } \\
\text { Radial } \\
\text { Stim. } \\
r^{\prime}{ }^{\prime}=30^{\prime}\end{array}$ & $\begin{array}{l}\text { Large } \\
\text { Radial } \\
\text { Stim. } \\
r^{\prime} w^{\prime}=60^{\prime}\end{array}$ & $\begin{array}{l}\text { Smal } \\
\text { Vertical } \\
\text { Fracture } \\
x f=150^{\prime}\end{array}$ & $\begin{array}{l}\text { Large } \\
\text { Vertical } \\
\text { Fracture } \\
x f=600^{\prime}\end{array}$ \\
\hline I & 543 & 4.1 & 0.84 & 1.16 & 1.41 & 1.58 & 2.35 \\
\hline II & 3,577 & 12.4 & 2.95 & 4.06 & 4.64 & 4.67 & 6.21 \\
\hline III & 2,869 & 4.4 & 1.46 & 1.98 & 2.25 & 2.33 & 3.04 \\
\hline IV & 2,641 & 24.8 & 0.84 & 1.35 & 1.73 & 1.78 & 3.38 \\
\hline v & 313 & 0.4 & 0.05 & 0.06 & 0.06 & 0.06 & NA \\
\hline VI & 1,035 & 3.3 & 0.04 & 0.07 & 0.10 & 0.09 & 0.20 \\
\hline TOTAL & 10,978 & 49.4 & 6.18 & 8.68 & 10.19 & 10.51 & 15.18 \\
\hline
\end{tabular}


Overall recovery efficiency, as percent recovery of gas in-place, ranges from $13 \%$ with borehole shooting to $31 \%$ with 1 arge vertical fracturing of the Ohio Devonian shales. Relatively high recovery efficiencies of $50 \%$ to $60 \%$ appear attainable in Areas I, II and III; much lower efficiencies of 6 to $16 \%$ are representative of Areas IV, V and VI, as shown on Table 9.

TABLE 9

RECOVERY EFFICIENCY BY AREA AND STIMULATION METHOD (Percent Recovery of Gas In-P1 ace [Lower Huron] in 40 Years)

\begin{tabular}{|c|c|c|c|c|c|}
\hline \multirow[b]{2}{*}{$\begin{array}{c}\text { Partitioned } \\
\text { Area } \\
\end{array}$} & \multicolumn{5}{|c|}{ Well Stimulation Method } \\
\hline & $\begin{array}{l}\text { Borehole } \\
\text { Shooting }\end{array}$ & $\begin{array}{c}\text { Small } \\
\text { Radial } \\
\text { Stimulation } \\
r^{\prime} w^{\prime}=30^{\prime} \\
\end{array}$ & $\begin{array}{c}\text { Large } \\
\text { Radial } \\
\text { Stimulation } \\
r^{\prime}=60^{\prime} \\
\end{array}$ & $\begin{array}{l}\text { Small } \\
\text { Vertical } \\
\text { Fracture } \\
x=150^{\prime} \\
\end{array}$ & $\begin{array}{l}\text { Large } \\
\text { Vertical } \\
\text { Fracture } \\
x_{f}=600^{\prime} \\
\end{array}$ \\
\hline$I$ & 20 & 28 & 34 & 38 & 57 \\
\hline II & 24 & 33 & 38 & 38 & 50 \\
\hline$I \Perp I$ & 33 & 45 & 57 & 53 & 69 \\
\hline IV & 3 & 6 & 7 & 7 & 14 \\
\hline v & 12 & 15 & 16 & 16 & NA \\
\hline VI & 1 & 2 & 3 & 3 & 6 \\
\hline OVERALI. & 13 & 18 & 21 & 23 & 31 \\
\hline
\end{tabular}

With advanced stimulation, overall recovery efficiency is $52 \%$ for the free gas in-place in the fracture and the matrix system. However, only about $27 \%$ of the gas absorbed in the organic kerogen is produced in 40 years, as shown in Table 10. 
TABLE 10

GAS RECOVERY EFFICIENCY BY AREA AND GAS SOURCE

(With Advanced Stimulation)

\begin{tabular}{|c|c|c|c|c|}
\hline $\begin{array}{l}\text { Partitioned } \\
\text { Area }\end{array}$ & $\begin{array}{l}\begin{array}{c}\text { Free Gas In } \\
\text { Fractures }\end{array} \\
(\%)\end{array}$ & $\begin{array}{l}\text { Free Gas In } \\
\frac{\text { Matrix }}{(\%)}\end{array}$ & $\begin{array}{l}\begin{array}{c}\text { Sorbed Gas In } \\
\text { Matrix }\end{array} \\
(\%)\end{array}$ & $\frac{\text { Total }}{\text { T\% }}$ \\
\hline I & 59 & 61 & 54 & 57 \\
\hline II & 57 & 52 & 50 & 50 \\
\hline I II & 69 & 70 & 67 & 69 \\
\hline IV & 18 & 14 & 14 & 14 \\
\hline v & 51 & 17 & 16 & 16 \\
\hline VI & 7 & 6 & 6 & 6 \\
\hline OVERALL & 58 & 54 & 27 & 31 \\
\hline
\end{tabular}

The relative contributions of the three in-place sources to technically recoverable gas (with advanced stimulation) are as follows:

Source of Gas $\frac{\text { Gas In-Place }}{\text { (ICf) }} \frac{\text { Technically Recoverable }}{\text { (TCf) (\% In-PTace) }}$

- Free gas in fractures $\quad 0.6 \quad 0.4 \quad 58$

- Free gas in matrix

$\frac{42.1}{49.4}$ TOTAL
6.7

$\begin{array}{lll}0.6 & 0.4 & 58 \\ 6.7 & 3.5 & 54\end{array}$

$\frac{11.3}{15.2} \quad \frac{27}{31}$

ine contribution of the three sources to technically recoverable gas, bs area, is shown on Table 11. 


$$
-69-
$$

TABLE 11

TECHNICALLY RECOVERABLE GAS, BY AREA AND GAS SOURCE (TCf)

(With Advanced Stimulation)

\begin{tabular}{|c|c|c|c|c|}
\hline $\begin{array}{l}\text { Partitioned } \\
\text { Area } \\
\end{array}$ & $\begin{array}{l}\text { Free Gas In } \\
\text { Fractures } \\
\text { (TCf) }\end{array}$ & $\begin{array}{c}\begin{array}{c}\text { Free Gas In } \\
\text { Matrix }\end{array} \\
\text { (TCt) }\end{array}$ & $\begin{array}{l}\text { Sorbed Gas In } \\
\frac{\text { Matrix }}{\text { (Tcf) }}\end{array}$ & $\frac{\text { Total }}{\text { (Tcf) }}$ \\
\hline 1 & 0.1 & 0.5 & 1.7 & 2.3 \\
\hline II & 0.1 & 0.5 & 5.6 & 6.2 \\
\hline I II & 0.2 & 2.3 & 0.5 & 3.0 \\
\hline IV & * & 0.2 & 3.2 & 3.4 \\
\hline$v$ & * & * & 0.1 & 0.1 \\
\hline$V I$ & $\star$ & * & 0.2 & 0.2 \\
\hline TOTAL & 0.4 & 3.5 & 11.3 & 15.2 \\
\hline
\end{tabular}

*Less than 0.1 TCf 
D. TECHNICALLY RECOVERABLE GAS, BY WELL

1. Cumulative Recovery

Cumulative gas recovery per well using advanced stimulation is highest (at 1,080 MMcf) in Area I and lowest in Area VI (at 47 MMcf). Table 12 shows the near-term gas recovery (5 and 10-year cumulatives) and the long-term (40-year cumulatives) per wel1, for each of the alternative stimulation methods, assuming 160-acre spacing. The general trend of cumulative producting using bare hold shooting is illustrated in Exhibit 17.

\section{Daily Production Rates}

First year gas production rates range from 238 Mcf/D in Area I with a large vertical fracture, to about $1 \mathrm{Mc} / \mathrm{D}$ in Area VI using borehole shooting. The gas production rate is highly sensitive to stimulation treatments, as shown on Table 13.

The data for Area I show that large vertical fractures can increase the gas production rate by nearly sevenfold in year 1 and by fourfold in year 5, over borehole shooting. In addition to the benefits of early production stimulation, ultimate recovery (in 40 years) is increased nearly threefold:

\begin{tabular}{|c|c|c|c|}
\hline Gas Production Rate & $\begin{array}{l}\text { Borehole } \\
\text { Shooting }\end{array}$ & $\begin{array}{l}\text { Large } \\
\text { Vertical } \\
\text { Fracture } \\
\end{array}$ & $\begin{array}{c}\text { Increase of } \\
\text { Vertical Fracture } \\
\text { Over Borehole Shooting } \\
(x-\text { fold }) \\
\end{array}$ \\
\hline $\begin{array}{l}\text { - Year } 1 \\
\text { - Year } 5\end{array}$ & $\begin{array}{l}36 \\
31\end{array}$ & $\begin{array}{l}238 \\
123\end{array}$ & $\begin{array}{l}6.6 \\
4.0\end{array}$ \\
\hline $\begin{array}{l}\text { U1 timate Recovery } \\
\text { (MMcf) }\end{array}$ & 386 & 1,080 & 2.8 \\
\hline
\end{tabular}

Similar increases in gas flow and recovery are evident in all of the areas of ohio except in Area $V$, where fracture permeability is already high, thus dampening the benefits of extensive well stimulation. 


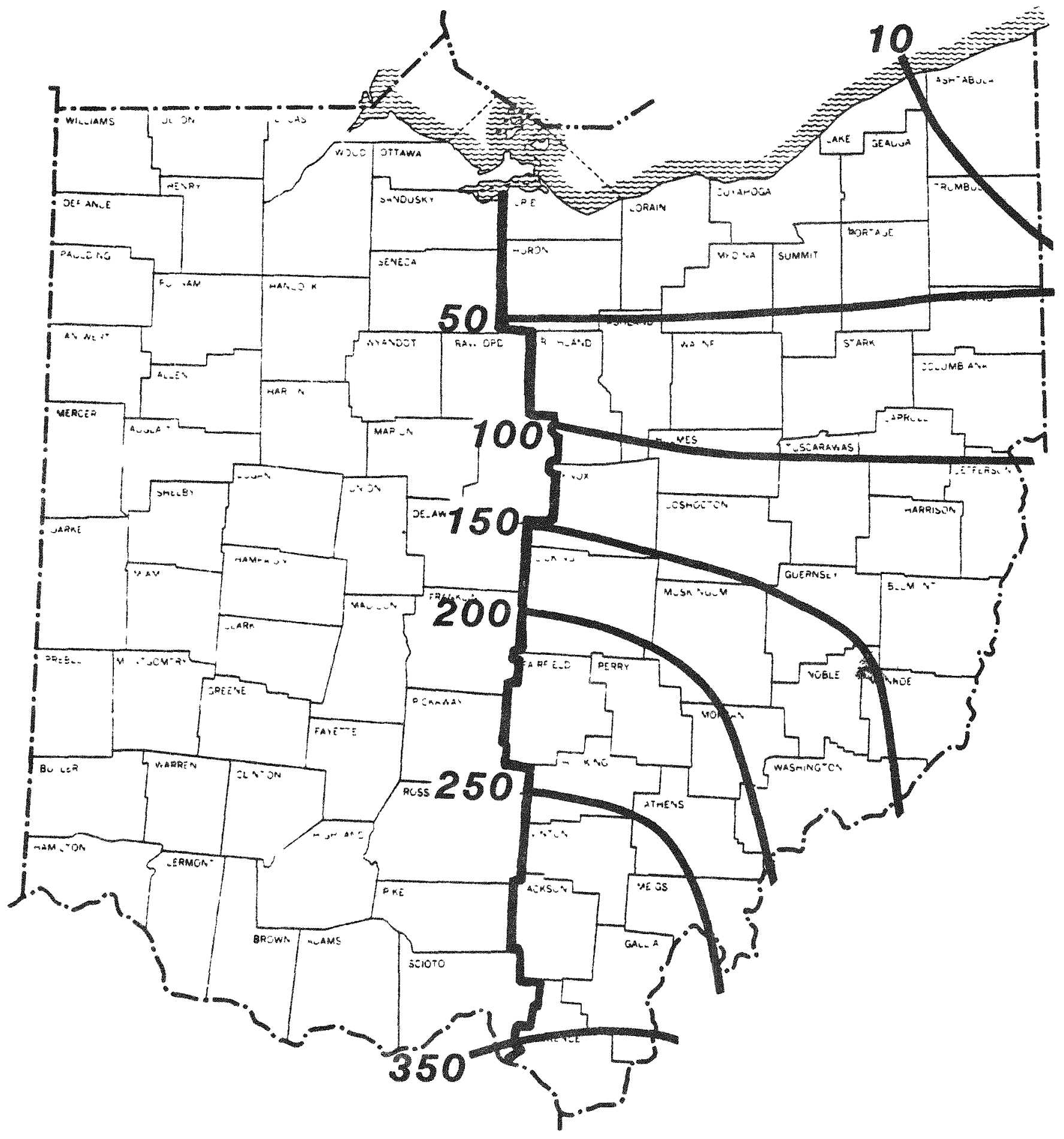


TABLE 12

PER WELL GAS RECOVERY, BY AREA AND STIMULATION METHOD

(Cumulative Recovery, MMcf)

\begin{tabular}{lcccc} 
& Small & Large & Smal1 & Large \\
Borehole & Radial & Radial & Vertical & Vertical \\
Shooting & Stimulation & Stimulation & Fracture & Fracture \\
& $r^{\prime} w=30^{\prime}$ & $r^{\prime} w=60^{\prime}$ & $x f=150^{\prime}$ & $x f=600^{\prime}$ \\
\hline
\end{tabular}

\begin{tabular}{rrrrrr}
\hline AREA I & & & & \\
5 Years & 61.3 & 96.3 & 129.3 & 161.3 & 344.1 \\
10 Years & 116.1 & 176.5 & 230.1 & 276.4 & 529.7 \\
40 Years & 386.4 & 536.1 & 650.4 & 729.8 & $1,080.0$
\end{tabular}

AREA II

$\begin{array}{rrrrrr}5 \text { Years } & 33.7 & 52.8 & 65.0 & 66.4 & 110.1 \\ 10 \text { Years } & 64.3 & 98.0 & 118.6 & 120.7 & 189.6 \\ 40 \text { Years } & 206.0 & 283.8 & 324.4 & 326.6 & 433.9\end{array}$

AREA III

$\begin{array}{rrrrrr}5 \text { Years } & 22.3 & 36.1 & 45.7 & 49.6 & 92.0 \\ 10 \text { Years } & 41.8 & 64.5 & 79.4 & 84.8 & 142.2 \\ 40 \text { Years } & 127.2 & 172.1 & 196.0 & 202.8 & 265.3\end{array}$

AREA IV

$\begin{array}{rrrrrr}5 \text { Years } & 10.7 & 18.4 & 24.4 & 25.6 & 55.8 \\ 10 \text { Years } & 21.1 & 35.6 & 47.0 & 49.0 & 103.4 \\ 40 \text { Years } & 79.1 & 127.9 & 163.9 & 168.4 & 320.0\end{array}$

AREA $V$

$\begin{array}{rrrrrr}5 \text { Years } & 5.6 & 7.0 & 7.7 & 7.5 & \text { NA } \\ 10 \text { Years } & 10.8 & 13.6 & 14.8 & 14.5 & \text { NA } \\ 40 \text { Years } & 38.8 & 47.2 & 51.0 & 51.0 & \text { NA }\end{array}$

AREA VI

$\begin{array}{rrrrrr}5 \text { Years } & 1.3 & 2.6 & 3.6 & 3.5 & 8.4 \\ 10 \text { Years } & 2.6 & 5.0 & 6.9 & 6.6 & 15.4 \\ 40 \text { Years } & 9.8 & 17.7 & 23.6 & 22.4 & 47.0\end{array}$


TABLE 13

PER WELL GAS PRODUCTION RATES, BY AREA AND STIMULATION METHOD

(Daily Production, Mcf/D)

\begin{tabular}{ccccc} 
& Small & Large & Small & Large \\
Borehole & Radial & Radial & Vertical & Vertical \\
Shooting & Stimulation & Stimulation & Fracture & Fracture \\
& $r^{\prime} w=30^{\prime}$ & $r^{\prime} w=60^{\circ}$ & $x f=150^{\prime}$ & $x_{f}=600^{\prime}$ \\
\hline
\end{tabular}

\begin{tabular}{rlllll}
\hline AREA I & & & & & \\
5 Years & 31 & 47 & 60 & 70 & 123 \\
10 Years & 29 & 42 & 52 & 59 & 90 \\
40 Years & 21 & 26 & 29 & 30 & 29
\end{tabular}

AREA II

$\begin{array}{rlllll}5 \text { Years } & 18 & 27 & 33 & 33 & 51 \\ 10 \text { Years } & 16 & 23 & 28 & 28 & 39 \\ 40 \text { Years } & 10 & 13 & 13 & 13 & 13\end{array}$

AREA III

$\begin{array}{rrrrrr}5 \text { Years } & 11 & 17 & 21 & 22 & 35 \\ 10 \text { Years } & 10 & 15 & 17 & 18 & 24 \\ 40 \text { Years } & 6 & 7 & 7 & 7 & 5\end{array}$

$\begin{array}{rrrrrr}\text { AREA IV } & & & & & \\ 5 \text { Years } & 6 & 10 & 13 & 13 & 28 \\ 10 \text { Years } & 6 & 9 & 12 & 12 & 25 \\ 40 \text { Years } & 5 & 8 & 10 & 10 & 17\end{array}$

AREA $V$

$\begin{array}{rlllll}5 \text { years } & 3 & 3.7 & 4 & 4.0 & \text { NA } \\ 10 \text { Years } & 3 & 3.5 & 3.8 & 3.8 & \text { NA } \\ 40 \text { Years } & 2.3 & 2.7 & 2.9 & 2.8 & \text { NA }\end{array}$

AREA VI

$\begin{array}{rlllll}5 \text { Years } & 0.7 & 1.4 & 1.9 & 1.8 & 4.2 \\ 10 \text { Years } & 0.7 & 1.3 & 1.7 & 1.7 & 3.7 \\ 40 \text { Years } & 0.6 & 1.1 & 1.4 & 1.3 & 2.5\end{array}$


E. DRILLING AREA AND DRILLING POTENTIAL

The undrilled and accessible area of Onio, underlaid by Devonian age gas-bearing shales, is 10,978 square miles, or 7,025,920 acres, distributed by partitioned area as follows:

\begin{tabular}{lrr} 
& \multicolumn{2}{c}{ Total Drillable Area } \\
\cline { 2 - 3 } & $\frac{\text { Square Miles }}{543}$ & $\frac{\text { Acres }}{347,520}$ \\
Area I & 3,577 & $2,289,280$ \\
Area II & 2,869 & $1,836,160$ \\
Area III & 2,641 & $1,690,240$ \\
Area IV & 313 & 200,320 \\
Area V & $\underline{1,035}$ & $\mathbf{6 6 2 , 4 0 0}$ \\
Area VI & 10,978 & $7,025,920$ \\
TOTAL & &
\end{tabular}

The number of wells required to "drill up" the 10,978 square miles of still undrilled and accessible area of ohio would be 43,911 to 87,822 , depending on the pattern spacing selected by the operator, as shown below:

Total

\begin{tabular}{l} 
Partitioned \\
Area \\
\hline
\end{tabular}

Area I

Area II

Area III

Area IV

Area $V$

Area VI

TOTAL

\begin{abstract}
Drillable Area
(M Acres)
\end{abstract}

348

2,289

1,836

1,690

200

$\frac{6,621}{7,026}$
Total Required Wells

\begin{tabular}{|c|c|}
\hline $\begin{array}{l}\text { At 160-Acre } \\
\text { Spacing/Well }\end{array}$ & $\begin{array}{l}\text { At } 80 \text {-Acre } \\
\text { Spacing/We } 11\end{array}$ \\
\hline 2,172 & 4,344 \\
\hline 14,308 & 28,616 \\
\hline 11,475 & 22,950 \\
\hline 10,563 & 21,126 \\
\hline 1,252 & 2,504 \\
\hline 4,141 & 8,282 \\
\hline 43,911 & 87,822 \\
\hline
\end{tabular}


F. NEED FOR AND VALUE OF ADVANCED WELL STIMULATION TECHNOLOGY

Analysis shows that advanced stimulation me thods add significant additional gas over borehole shooting. Previously, it had been assumed that merely linking the natural fracture system to the wellbore was sufficient to achieve efficient gas recovery, and that the greater the number of natural fractures connected, the greater the resulting gas recovery.

This analysis showed, however, that a higher conductivity path than provided by the natural fracture system is required to achieve efficient gas flow rates. This is because the permeability in the natural fracture system is too low $(0.02$ to $0.30 \mathrm{md})$ to provide adequate conductivity; thus, an induced fracture with proppants and high conductivity is required for efficient gas recovery.

The expected increase in gas productivity, due to the application of advanced well stimulation, must be weighed against the extra cost of the stimulation treatment. One method for so doing is to determine if the additional expense of the stimulation treatment could be paid back over a specified period of time.

The table below indicates the incremental gas production (MMcf) over borehole shooting in Areas $I$ and $I I$ in 5 years:

Incremental Gas Recovery, In Five Years, Over Borehole

Type of Stimulation

Small Radial Stimulation

Large Radial Stimulation

Small Vertical Fracture

Large Vertical Fracture
Shooting (MMlcf/Well)

\begin{tabular}{|c|c|}
\hline Area I & Area II \\
\hline 35.0 & 19.1 \\
\hline 68.0 & 31.3 \\
\hline 100.6 & 32.7 \\
\hline 282.8 & 76.4 \\
\hline
\end{tabular}


If a 5-year payoff period is adequate and a wellhead value of $\$ 3 /$ Mcf is assumed for the additional gas produced, a large vertical fracture treatment would be desirable in Area I if it cost less than $\$ 800,000$. Similarly, in Area II, a large radial stimulation would be cost-effective if it could be accomplished for under $\$ 100,000$.

Table 14 provides the incremental gas recovery over borehole shooting (by area) for each of the stimulation methods. 
TABLE 14

INCREMENTAL GAS PRODUCTION OVER BOREHOLE SHOOTING

(Cumulative Recovery, MMcf)

\begin{tabular}{ccccc} 
Small & Large & Small & Large & Improvement in \\
Radial & Radial & Vertical & Vertical & Large Vertical \\
Stimulation & Stimulation & Fracture & Fracture & Frac. vs. Borehole \\
$r^{\prime} w=30^{\prime}$ & $r_{w}^{\prime}=60^{\prime}$ & $x_{f}=150^{\prime}$ & $x_{f}=600^{\prime}$ & Shooting (x-fold) \\
\hline
\end{tabular}

AREA I

$\begin{array}{rrrrrr}10 \text { Years } & 60.4 & 114.0 & 160.3 & 413.6 & 4.6 \\ 40 \text { Years } & 149.7 & 264.0 & 343.4 & 693.6 & 2.8\end{array}$

AREA II

40 Years

33.7

54.3

56.4

125.3

2.9

77.8

118.4

120.6

227.9

2.1

AREA III

10 Years

22.7

37.6

43.0

100.4

3.4

40 Years

44.9

68.8

75.6

138.1

2.1

\section{AREA IV}

10 Years

14.5

25.9

27.9

82.3

4.9

40 Years

48.8

84.8

89.3

240.9

4.0

\section{AREA V}

10 Years

2.8

4.0

3.7

NA

NA

40 Years

8.4

12.2

12.2

NA

NA

\section{AREA VI}

10 Vears

2.4

4.3

4.0

12.8

5.9

40 Years

7.9

13.8

12.6

37.2

4.8 
G. REVIEW OF TECHNICALLY RECOVERABLE GAS, BY AREA

The analysis showed that the gas flow rates and ultimate recovery per well vary widely in ohio, from relatively high gas production in the south to low production rates in the shallow, northern area along Lake Erie. The gas potential and production of the six partitioned areas of ohio are discussed below:

Area I. The southern portion of Ohio, Lawrence and Gallia Counties, contains 543 drillable square miles and an estimated 4.1 Tcf of gas in-place. Because of favorable reservoir properties, such as high pressure, good net thickness and close fracture spacing (5 to 10 feet), gas recoveries per well are high, from 386 MMcf with borehole shooting up to 1,080 MMcf with large vertical fracturing. First year gas production ranges from $36 \mathrm{Mcf} / \mathrm{D}$ (borehole shooting) to $238 \mathrm{Mcf} / \mathrm{D}$ (1)argt vertical fracturing). Little permeability anisotropy is noted for this area. The major technical concern is being able to contain induced vertical fractures without intersecting water aquifers, particularly in Gallia county.

Area II. The west-central part of Onio, Licking, Meigs, and other counties, has 3,577 drillable square miles and an estimated 12.4 Tcf of gas in-place. Lower rock pressures and net pay and more widely spaced natural fractures lead to moderate per well recoveries of 206 Mcf (borehole shooting) and 434 MMcf (1 arge vertical fracturing). First year gas production ranges from $19 \mathrm{McF} / \mathrm{D}$ (borehole shooting) to $68 \mathrm{Mcf} / \mathrm{D}$ (large vertical fracturing). High pemeability anisotropy (ratio of 6 to 1 ) and low intersection angle $\left(10^{\circ}\right)$ between the induced and naturai fracture systems tend to limit the efficiency of vertically induced fractures. Lower depths, and thus lower drilling costs per well, particularly in the western counties, tend to counterbalance lower gas recoveries.

Area 1II. The east-central part of Ohio, Gurnsey, Washington, and other counties, has 2,869 drillable acres and an estimated 4.4 Tcf of gas in-place. Small adsorbed gas content, low fracture permeability, and 
relatively widely spaced natural fractures limit per well recoveries to 127 MMcf (borehole shooting) and 265 MMcf (1 arge vertical fracturing). Moderate permeability anisotropy and a low fracture intersection angle $\left(20^{\circ}\right) 7$ imit the effectiveness of vertically induced fractures. Low fracture permeability $(0.02 \mathrm{md})$ and high overburden pressure argue for the use of substantial amounts of proppants with stimulation treatments.

Area IV. The north-central part of Ohio, Wayne, Stark, and other counties, has 2,641 drillable acres and 24.8 Tcf of gas inoplace. stimulation technology appears to be particularly effective in this area, raising per well recoveries from 79 MMcf (borehole shooting) to 320 MMcf with large vertical fracturing. The gas production curve, even though it starts Iow, 6 Mcf/D (borehole shooting) and 32 Mcf/D 11 arge vertical fracturing), tends to decline little, because of the high adsorbed gas content. Due to low rock pressure, large scale fracturing treatments will need fluids with enhanced clean-up capability and may not be feasible in the northern segment of Area IV.

Areas $V$ and VI. These two smaller areas in the northwest and northeast portions of ohio. Huron. Trumbul" and other counties, have 1,348 drillabie square miles and 3.7 Tcf of gas in-place. Per well recoveries are low, at about 50 MMcf per well (with advanced stimulation) as are the initial daily production rates of 1 to 4 Mcf per day. Large vertical fracturing, because of low overburden and rock pressures, is not possible in Area $V$ and may not be possible in Area VI. While these tw areas are somewhat similar in gas production, fracture spacing and pemeability anisotropy, the setting for the resource base is widely different. Area $V$ has high gas content (200 MCf/AF), particularly adsorbed gas, but limited net pay. Area VI has low gas content (50 Mcf/AF) with a thick productive interval and very low fracture pemeability $(0.02 \mathrm{md})$.

Tables 15 through 26 provide more detailed information on cumulative gas recovery and daily gas production rates, by stimulation method, for the six partitioned areas of ohio. 
TABLE 15

CUMULATIVE GAS RECOVERY BY TYPE OF STIMULATION (MMCF)

(One Well Per 160 Acres)

AREA I

Stimulation Method

\begin{tabular}{lllll}
\hline & Small & Large & Small & Large \\
Borehole & Radial & Radial & Vertical & Vertical \\
Shooting & Stimulation & Stimulation & Fracture & Fracture \\
& $r^{\prime} w=30^{\prime}$ & $r^{\prime} w=60^{\circ}$ & $x_{f}=150^{\circ}$ & $x_{f}=600^{\prime}$ \\
\hline
\end{tabular}

$\begin{array}{rrrrrr}1 & 13.8 & 23.4 & 33.5 & 46.5 & 123.4 \\ 5 & 61.3 & 96.3 & 129.3 & 161.3 & 344.1 \\ 10 & 116.1 & 176.5 & 230.1 & 276.4 & 529.7 \\ 20 & 216.2 & 316.2 & 399.3 & 463.6 & 786.8 \\ 40 & 386.4 & 536.1 & 650.4 & 729.8 & 1,080.0\end{array}$

TABLE 16

AVERAGE DAILY GAS PRODUCTION BY TYPE UF STIMULATION (MCF/D)

AREA I

Stimulation Me thod

\begin{tabular}{cccccc} 
& $\begin{array}{c}\text { Sorehole } \\
\text { Year }\end{array}$ & $\begin{array}{c}\text { Radial } \\
\text { Stimulation } \\
r^{\prime} w^{\prime}=30^{\prime}\end{array}$ & $\begin{array}{c}\text { Large } \\
\text { Radial } \\
\text { Stimulation } \\
r^{\prime} w^{\prime}=60^{\prime}\end{array}$ & $\begin{array}{c}\text { Small } \\
\text { Vertical } \\
\text { Fracture } \\
x f=150^{\prime}\end{array}$ & $\begin{array}{c}\text { Large } \\
\text { Vertical } \\
\text { Fracture } \\
x f=600^{\prime}\end{array}$ \\
\hline 1 & 36 & 58 & & & \\
5 & 31 & 47 & 60 & 103 & 238 \\
10 & 29 & 42 & 52 & 70 & 123 \\
20 & 26 & 35 & 47 & 59 & 90 \\
40 & 21 & 26 & 29 & 46 & 57 \\
& & & & 30 & 29
\end{tabular}


TABLE 17

CUMULATIVE GAS RECOVERY BY TYPE UR STIMULATION (MMCF)

(One Well Per 160 Acres)

AREA II

Stimulation Method

\begin{tabular}{rrrrrr}
\cline { 2 - 3 } & $\begin{array}{c}\text { Borehole } \\
\text { Shooting }\end{array}$ & $\begin{array}{c}\text { Smal1 } \\
\text { Radial } \\
\text { Stimulation } \\
r^{\prime} w=30^{\prime}\end{array}$ & $\begin{array}{c}\text { Large } \\
\text { Radial } \\
\text { Stimulation } \\
r_{w}^{\prime}=60^{\prime}\end{array}$ & $\begin{array}{c}\text { Smal1 } \\
\text { Vertical } \\
\text { Fracture } \\
x_{f}=150^{\prime}\end{array}$ & $\begin{array}{c}\text { Large } \\
\text { Vertical } \\
\text { Fracture } \\
x_{f}=600\end{array}$ \\
\hline 1 & 7.1 & 11.4 & 14.3 & 14.7 & 26.1 \\
5 & 33.7 & 52.8 & 65.0 & 66.4 & 110.1 \\
10 & 64.3 & 98.0 & 118.6 & 120.7 & 189.6 \\
20 & 118.5 & 173.3 & 204.8 & 207.3 & 302.1 \\
40 & 206.0 & 283.8 & 324.4 & 326.6 & 433.9
\end{tabular}

TABLE 18

AVERAGE DAILY GAS PRODUCTION BY TYPE OF STIMULATION (MCF/D)

AREA II

Stimulation Method

\begin{tabular}{|c|c|c|c|c|c|}
\hline \multirow[b]{2}{*}{ Year } & \multicolumn{5}{|c|}{ Stimulation Me thod } \\
\hline & $\begin{array}{l}\text { Borehole } \\
\text { Shooting }\end{array}$ & $\begin{array}{c}\text { Small } \\
\text { Radial } \\
\text { Stimulation } \\
r_{w}^{\prime}=30^{\circ}\end{array}$ & $\begin{array}{c}\text { Large } \\
\text { Radial } \\
\text { Stimulation } \\
r^{\prime}=60^{\circ}\end{array}$ & $\begin{array}{l}\text { Small } \\
\text { Vertical } \\
\text { Fracture } \\
x_{f}=150^{\circ}\end{array}$ & $\begin{array}{l}\text { Large } \\
\text { Vertical } \\
\text { Fracture } \\
x_{f}=600\end{array}$ \\
\hline
\end{tabular}

$\begin{array}{rrrrrr}1 & 19 & 31 & 38 & 39 & 68 \\ 5 & 18 & 27 & 33 & 33 & 51 \\ 10 & 16 & 23 & 28 & 28 & 39 \\ 20 & 14 & 19 & 21 & 21 & 25 \\ 40 & 10 & 13 & 13 & 13 & 13\end{array}$


TABLE 19

CUMULATIVE GAS RECOVERY BY TYPE OF STIMULATION (MMCF)

(One Well Per 160 Acres)

AREA III

Stimulation Method

\begin{tabular}{llccc}
\hline & Small & Large & Small & Large \\
Borehole & Radial & Radial & Vertical & Vertical \\
Shooting & Stimulation & Stimulation & Fracture & Fracture \\
& $r^{\prime} w=30^{\prime}$ & $r^{\prime} w=00^{\prime}$ & $x_{f}=150^{\prime}$ & $x_{f}=600^{\prime}$ \\
\hline
\end{tabular}

$\begin{array}{rrrrrr}1 & 5.0 & 8.8 & 11.7 & 13.3 & 29.8 \\ 5 & 22.3 & 36.1 & 45.7 & 49.6 & 92.0 \\ 10 & 41.8 & 64.5 & 79.4 & 84.8 & 142.2 \\ 20 & 75.4 & 109.9 & 130.7 & 137.5 & 204.6 \\ 40 & 127.2 & 172.1 & 196.0 & 202.8 & 265.3\end{array}$

TABLE 20

AVERAGE DAILY GAS PRODUCTION BY TYPE OF STIMULATION (MCF/D)

AREA III

Stimulation Method

\begin{tabular}{|c|c|c|c|c|c|}
\hline Year & $\begin{array}{l}\text { Borehole } \\
\text { Shooting }\end{array}$ & $\begin{array}{c}\text { Small } \\
\text { Radial } \\
\text { Stimulation } \\
r_{w}^{\prime}=30^{\circ}\end{array}$ & $\begin{array}{c}\text { Large } \\
\text { hadial } \\
\text { Stimulation } \\
r_{w}^{\prime}=60^{\prime}\end{array}$ & $\begin{array}{l}\text { Small } \\
\text { Vertical } \\
\text { Fracture } \\
x f=150^{\circ}\end{array}$ & $\begin{array}{l}\text { Large } \\
\text { Vertical } \\
\text { Fracture } \\
x f=600\end{array}$ \\
\hline 1 & 13 & 22 & 29 & 31 & 63 \\
\hline 5 & 11 & 17 & 21 & 22 & 35 \\
\hline 10 & 10 & 15 & 17 & 18 & 24 \\
\hline 20 & 8 & 11 & 12 & 12 & 13 \\
\hline 40 & 6 & 7 & 7 & 7 & 5 \\
\hline
\end{tabular}


TABLE 21

CUMULATIVE GAS RECOVERY BY TYPE OF STIMULATION (MMCF)

(One Well Per 160 Acres)

AREA IV

Stimulation Method

\begin{tabular}{|c|c|c|c|c|c|}
\hline Year & $\begin{array}{l}\text { Borehole } \\
\text { Shooting }\end{array}$ & $\begin{array}{c}\text { Small } \\
\text { Radial } \\
\text { Stimulation } \\
r_{w}^{\prime}=30^{\prime} \\
\end{array}$ & $\begin{array}{c}\text { Large } \\
\text { Radial } \\
\text { Stimulation } \\
r_{w}^{\prime}=60^{\prime}\end{array}$ & $\begin{array}{l}\text { Small } \\
\text { Vertical } \\
\text { Fracture } \\
x_{f}=150^{\prime} \\
\end{array}$ & $\begin{array}{l}\text { Large } \\
\text { Vertical } \\
\text { Fracture } \\
x f=600 \\
\end{array}$ \\
\hline 1 & 2.2 & 3.8 & 5.1 & 5.4 & 12.2 \\
\hline 5 & 10.7 & 18.4 & 24.4 & 25.6 & 55.8 \\
\hline 10 & 21.1 & 35.6 & 47.0 & 49.0 & 103.4 \\
\hline 20 & 41.1 & 68.1 & 88.7 & 92.0 & 185.5 \\
\hline 40 & 79.1 & 127.9 & 163.9 & 168.4 & 320.0 \\
\hline
\end{tabular}

TABLE 22

AVERAGE DAILY GAS PRUCUCTION BY TYPE OF STIMULATION (MCF/D)

AREA IV

Stimulation Me thod

\begin{tabular}{|c|c|c|c|c|c|}
\hline Year & $\begin{array}{l}\text { Borehole } \\
\text { Shooting }\end{array}$ & $\begin{array}{c}\text { Small } \\
\text { Radial } \\
\text { Stimulation } \\
r^{\prime}=30^{\circ}\end{array}$ & $\begin{array}{c}\text { Large } \\
\text { Radial } \\
\text { Stimulation } \\
r_{W}^{\prime}=60^{\circ}\end{array}$ & $\begin{array}{l}\text { Small } \\
\text { Vertical } \\
\text { Fracture } \\
x_{f}=150^{\circ}\end{array}$ & $\begin{array}{l}\text { Large } \\
\text { Vertical } \\
\text { Fracture } \\
x_{f}=600^{\prime}\end{array}$ \\
\hline
\end{tabular}

$\begin{array}{rrrrrr}1 & 6 & 11 & 14 & 15 & 32 \\ 5 & 6 & 10 & 13 & 13 & 28 \\ 10 & 6 & 9 & 12 & 12 & 25 \\ 20 & 5 & 9 & 11 & 11 & 21 \\ 40 & 5 & 8 & 10 & 10 & 17\end{array}$


TABLE 23

CUMULATIVE GAS RECOVERY BY TYPE OF STIMULATION (MMCF)

(One Well Per 160 Acres)

AREA V

\begin{tabular}{rrrrr} 
& \multicolumn{5}{c}{ Stimulation Method } \\
\cline { 2 - 5 } Year & $\begin{array}{c}\text { Borehole } \\
\text { Shooting }\end{array}$ & $\begin{array}{c}\text { Small } \\
\text { Radial } \\
\text { Stimulation } \\
r^{\prime}{ }^{\prime}=30^{\prime}\end{array}$ & $\begin{array}{c}\text { Large } \\
\text { Radial } \\
\text { Stimulation } \\
r^{\prime} w=60^{\prime}\end{array}$ & $\begin{array}{c}\text { Small } \\
\text { Vertical } \\
\text { Fracture } \\
\text { Xf }=150^{\prime}\end{array}$ \\
\hline 1 & 1.2 & 1.5 & 1.7 & 1.6 \\
5 & 5.6 & 7.0 & 7.7 & 7.5 \\
10 & 10.8 & 13.6 & 14.8 & 14.5 \\
20 & 20.8 & 25.8 & 28.0 & 27.5 \\
40 & 38.8 & 47.2 & 51.0 & 51.0
\end{tabular}

TABLE 24

AVERAGE DAILY GAS PRODUCTION BY TYPE OF STIMULATION (MCF/D)

AREA $Y$

Stimulation Me thod

\begin{tabular}{rcccc}
\cline { 2 - 5 } Year & $\begin{array}{c}\text { Borehole } \\
\text { Shooting }\end{array}$ & $\begin{array}{c}\text { Small } \\
\text { Radial } \\
\text { Stimulation } \\
r^{\prime} w^{\prime}=30^{\circ}\end{array}$ & $\begin{array}{c}\text { Large } \\
\text { Radial } \\
\text { Stimulation } \\
r^{\prime} w^{\prime}=60^{\circ}\end{array}$ & $\begin{array}{c}\text { Small } \\
\text { Vertical } \\
\text { Fracture } \\
x_{f}=150^{\prime}\end{array}$ \\
\hline 1 & 3 & 3.8 & 4.0 & 4.1 \\
5 & 3 & 3.7 & 4.0 & 4.0 \\
10 & 3 & 3.5 & 3.8 & 3.8 \\
20 & 2.6 & 3.2 & 3.5 & 3.4 \\
40 & 2.3 & 2.7 & 2.9 & 2.8
\end{tabular}


TABLE 25

CUMULATIVE GAS RECOVERY BY TYPE OF STIMULATION (MMCF)

(One Well Per 160 Acres)

AREA VI

Stimulation Method

\begin{tabular}{rccccc} 
Year & $\begin{array}{c}\text { Borehole } \\
\text { Shooting }\end{array}$ & $\begin{array}{c}\text { Smal1 } \\
\text { Radial } \\
\text { Stimulation } \\
r^{\prime}{ }_{w}=\text { su }^{\prime}\end{array}$ & $\begin{array}{c}\text { Large } \\
\text { Radial } \\
\text { Stimulation } \\
r_{w}^{\prime}{ }_{w}=60^{\prime}\end{array}$ & $\begin{array}{c}\text { Small } \\
\text { Vertical } \\
\text { Fracture } \\
x_{f}=150^{\prime}\end{array}$ & $\begin{array}{c}\text { Large } \\
\text { Vertical } \\
\text { Fracture } \\
x_{f}=600^{\prime}\end{array}$ \\
\hline & & & & & \\
5 & 0.3 & 0.5 & 0.8 & 0.7 & 1.9 \\
10 & 1.3 & 2.6 & 3.6 & 3.5 & 8.4 \\
20 & 2.6 & 5.0 & 6.9 & 6.6 & 15.4 \\
40 & 5.1 & 9.5 & 12.9 & 12.3 & 27.4 \\
& 9.8 & 17.7 & 23.6 & 22.4 & 47.0
\end{tabular}

TABLE 26

AVERAGE DAILY GAS PROLUCTION BY TYPE OF STIMULATION (MCF/D)

AREA VI

Stimulation Method

\begin{tabular}{|c|c|c|c|c|c|}
\hline Year & $\begin{array}{l}\text { Borehole } \\
\text { Shooting }\end{array}$ & $\begin{array}{c}\text { Small } \\
\text { Radial } \\
\text { Stimulation } \\
r^{\prime} w=30^{\circ}\end{array}$ & $\begin{array}{c}\text { Large } \\
\text { Radial } \\
\text { Stimulation } \\
r_{W}^{\prime}=60^{\prime}\end{array}$ & $\begin{array}{l}\text { Small } \\
\text { Vertical } \\
\text { Fracture } \\
x_{f}=150^{\circ}\end{array}$ & $\begin{array}{l}\text { Large } \\
\text { Vertical } \\
\text { Fracture } \\
x_{f}=600^{\prime}\end{array}$ \\
\hline
\end{tabular}

$\begin{array}{rrrrrr}1 & 0.7 & 1.5 & 2.0 & 2.0 & 4.9 \\ 5 & 0.7 & 1.4 & 1.9 & 1.8 & 4.2 \\ 10 & 0.7 & 1.3 & 1.7 & 1.7 & 3.7 \\ 20 & 0.7 & 1.2 & 1.6 & 1.5 & 3.0 \\ 40 & 0.6 & 1.1 & 1.4 & 1.3 & 2.5\end{array}$


VII. OTHER FACTORS AFFECTING PRODUCTION

The findings in this study hinge greatty on a series of key assumptions as to geologic characteristics, induced fracture performance, and drainage pattern size and shape. Many of these assumptions are based on theoretical and computer analysis and need to be field verified in practice. To better understand the importance of these assumptions, this section examines the effects on gas recovery of: (1) reduced pattern size; (2) induced fracture behavior at intersection with natural fractures; (3) linkage of wellbore to the natural fracture system; (4) aiternative pattern shape, and (5) coproduction with oil-bearing shales.

\section{A. REDUCED PATTERN SIZE}

The traditional field development practice is to use a well spacing of 150 to 160 acres, drilled on a square pattern. The analysis shows that, with this spacing, a considerable portion of the gas in-place remains unrecoverable even after 40 years. Today, current practice is to drill on smaller acreage. This analysis therefore examines the recovery efficiencies and feasibility of reducing pattern size to 80 acres per well.

While closer drilling will give a higher overall gas recovery from a given area, the feasibility of drilling on smaller patterns has to be weighed against the expense of the additional well and stimulation. For example, the table below illustrates the effects on cumulative gas production, for the first ten years, of drilling one and two wells on 160 acres in Area I:

Effect of In-Fil1 Drilling
(10 Year Cumulative Gas Recovery, MMcf)

160 Acres
Incremental Gas
IWell 2 For Second Well

Borehole Shooting Large Vertical Fracture
116

530
226

941
110

411 
The table above shows that drilling on 80-acre spacing would yield an additional 110 MMcf (over the first 10 years) using borehole shooting, and an additional 411 MMcf (in 10 years), using large vertical fracturing. Tables 27-31 provide this data for selected stimulation techniques 110 year and 40 year recoveries) for each of the six areas.

An overall review of the data indicates that reduced well spacing could be effective in Areas I and IV, marginally effective in Areas II and III, and not effective in Area $V$. If the low rates of gas production in Area VI can be justified by local gas usage, even closer spacing than 80 acres per well would be preferred. 
TABLE 27

SELECTION OF WELL SPACING

AREA I

- Cumulative Gas Production in 10 Years (MMcf)

Stimulation Technique

Borehole Shooting

Small Radial

Large Radial

Small Vertical Fracture

Large Vertical Fracture

\begin{tabular}{|c|c|c|}
\hline \multicolumn{2}{|c|}{ 160-Acre Area } & Incremental Gas \\
\hline 1 Wel1 & 2 Wel1s & For Second Well \\
\hline 116 & 226 & 110 \\
\hline 177 & 338 & 161 \\
\hline 230 & 433 & 203 \\
\hline 276 & 523 & 247 \\
\hline 530 & 941 & 411 \\
\hline
\end{tabular}

- Cumulative Gas Production in 40 Years (MMcf)

Stimulation Technique

Borehole Shooting

Small Radial

Large Radial

Small Vertical Fracture

Large Vertical Fracture

\begin{tabular}{cccc}
\multicolumn{2}{c}{160 -Acre Area } & & Incremental Gas \\
\cline { 1 - 2 }$\frac{1 \text { Well }}{386}$ & $\frac{2 \text { Wells }}{656}$ & & For Second Well \\
536 & 860 & & 3270 \\
650 & 998 & 348 \\
730 & 1,102 & 372 \\
1,080 & 1,431 & 351
\end{tabular}


TABLE 28

SELECTION OF WELL SPACING

AREA II

- Cumulative Gas Production in 10 Years (MMcf)

Stimulation Technique

Large Radial Stimulation

Large Vertical Fracture

\begin{tabular}{|c|c|c|}
\hline 160-Acre & Area & Incremental Gas \\
\hline 1 Well & 2 wells & For Second well \\
\hline 119 & 194 & 75 \\
\hline 190 & 282 & 92 \\
\hline
\end{tabular}

- Cumulative Gas Production in 40 Years (MMcf)

Stimulation Technique

Large Radial Stimulation

Large Vertical Fracture

\begin{tabular}{|c|c|c|}
\hline \multicolumn{2}{|c|}{ 160-Acre Area } & Incremental Gas \\
\hline 1 Well & 2 Wells & For Second Well \\
\hline 324 & 446 & 122 \\
\hline 434 & 538 & 104 \\
\hline
\end{tabular}

TABLE 29

SELECTION OF WELL SPACING

AREA III

- Cumulative Gas Production in 10 Years (MMcf)

Stimulation Technique

Large Radial Stimulation

$\frac{160 \text {-Acre Area }}{\frac{1 \text { Well }}{79}} \frac{2 \text { Wells }}{138}$

Incremental Gas

Large Vertical Fracture

142

224

82

- Cumulative Gas Production in 40 Years (MMcf)

Stimulation Technique

Large Radial Stimulation

Large Vertical Fracture

\begin{tabular}{|c|c|c|}
\hline 160-Acre & Area & Incremental Gas \\
\hline 1 Well & 2 Wells & For Second Well \\
\hline 196 & 266 & 70 \\
\hline 265 & 316 & 51 \\
\hline
\end{tabular}


TABLE 30

SELECTION OF WELL SPACING

AREA IV

- Cumulative Gas Production in 10 Years (MMcf)

Stimulation Technique

Large Radial Stimulation

Large Vertical Fracture

\begin{tabular}{|c|c|c|}
\hline \multicolumn{2}{|c|}{ 160-Acre Area } & Incremental Gas \\
\hline 1 Well & 2 We11s & For Second Well \\
\hline 47 & 92 & 45 \\
\hline 103 & 202 & 99 \\
\hline
\end{tabular}

- Cumulative Gas Production in 40 Years (MMcf)

Stimulation Technique Large Radial Stimulation Large Vertical Fracture

\begin{tabular}{|c|c|c|}
\hline \multicolumn{2}{|c|}{ 160-Acre Area } & Incremental Gas \\
\hline 1 Well & 2 Wells & For Second Well \\
\hline 164 & 312 & 148 \\
\hline 320 & 586 & 266 \\
\hline
\end{tabular}

TABLE 31

SELECTION OF WELL SPACING

AREA V AND VI

- Cumulative Gas Production in 10 Years (MMcf)

Stimulation Technique

Large Radial Stimulation

Area $V$

Area VI

\begin{tabular}{lll}
$\frac{160-\text { Acre Area }}{1 \text { Well }} 2$ Wells & Incremental Gas \\
\hline
\end{tabular}

15

18

3

$7 \quad 14$

- Cumulative Gas Production in 40 Years (MMcf)

Stimulation Technique

Large Radial Stimulation

Area $V$

Area VI

\begin{tabular}{|c|c|c|}
\hline 160-Acre & Area & Incremental Gas \\
\hline 1 Well & 2 Wells & For Second well \\
\hline
\end{tabular}

51

24

60

46

22 
B. ALTERNATIVE INDUCED FRACTURE BEHAVIOR AT NATURAL FRACTURE INTERSECTIONS

The analysis assumes that an induced fracture will enter and propagate along the same path as the natural fracture system. However, two other possibilities could occur:

- The induced fracture could enter the natural fracture system and teminate due to energy dissipation at the interface; or,

- The induced fracture could cross the natural fracture system for the full fracture design length.

These three alternatives are shown schematically on Exhibit 18.

\section{Low Fracture Intersection Angle}

In areas having a low induced fracture intersection angle (with the natural fracture system), it appears to make little difference whether the fracture parallels or crosses the natural fracture system. However, with a large scale stimulation (a 600-foot induced fracture) substantial improvement in gas recovery results when the induced fracture parallels (providing a well propped, highly conductive flow path) rather than terminates in the first natural fracture system encountered.

The table below indicates the results of this analysis in Area II, which has a fracture intersection angle of 10 degrees.

Effect of Alternative Induced Fracture Perfomance Low Angle Case (Cumulative Recovery, MMcf) Terminates In Parallels crosses Natural Frac Natural Frac Natural Frac

Stimulation Technique

System
System System

Small Vertical Fracture $\left(x_{f}=150^{\prime}\right)$ To Years 40 Years

Large Vertical Fracture $\left(x_{f}=600^{\prime}\right)$ 


\section{-92 - \\ Exhibit 18 \\ UNDERSTANDING OF INDUCED FRACTURE PROPAGATION}

FRACTURE ARRESTED AT INTERSECTION WITH NATURAL FRACTURE

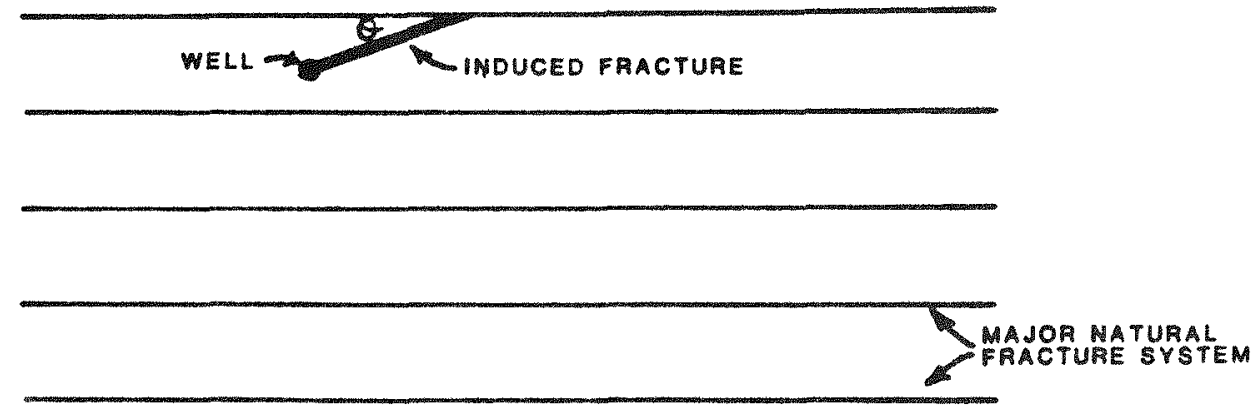

FRACTURE PROPAGATES ALONG NATUAAL FRACTURE (Normal Case)

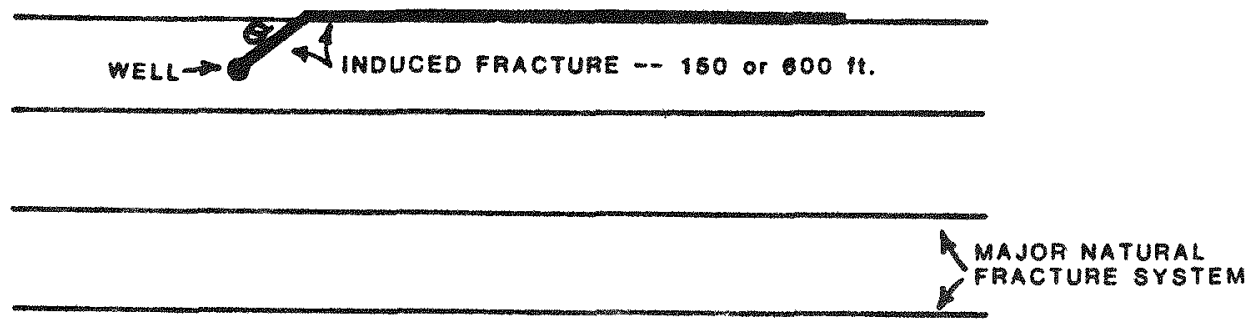

FRACTURE CROSSES NATURAL FRACTURE

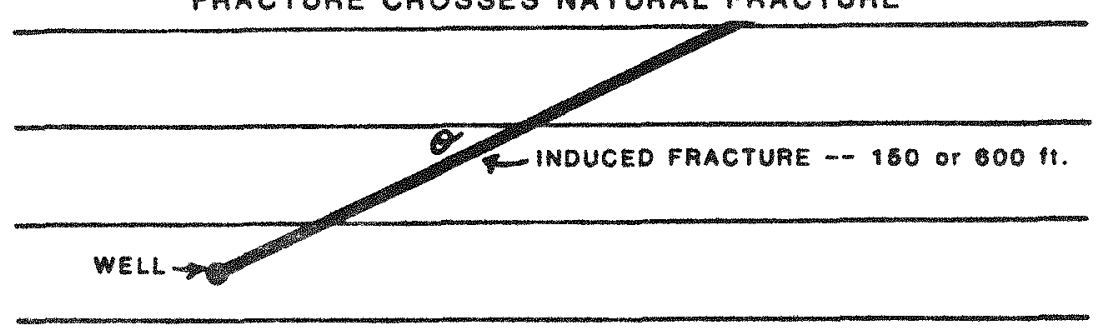


For Area II, crossing the natural fracture system results in only a small ( 3 percent) increase in gas recovery for both the small and 1 arge vertical fracture cases. However, should the induced fracture merely teminate in the natural fracture system, gas recovery could be severely reduced--by 20 percent for the smal1, 150-foot vertical fracture case, and by 50 percent for the large, 600-foot vertical fracture case.

\section{High Fracture Intersection Angle}

At higher fracture intersection angles such as 40 degrees, the positive effects of crossing a natural fracture system become evident. In this type of setting, the induced fracture presents a high permeability surface area partially orthogonal to the direction of greater natural permeability.

The reservoir properties of Area IV, which has a 40 degree intersection angle and a permeability anisotropy ratio of $6: 1$, are used to examine the effect of fracture intersection angle.

Effect of Induced Alternative Fracture Performance High Angle Case (Cumulative Recovery, MMcf) Parallels Crosses

Stimulation Technique Natural Frac

Small Vertical Fracture $\left(x_{f}=150^{\prime}\right)$ System Natural Frac system

10 Years

40 Years

Large Vertical Fracture $\left(x_{f}=600^{\prime}\right)$
10 Years

40 Years
49

168

103

320
74

243

159

461

In this area, crossing the natural fracture system increases gas recovery by 40 to 50 percent over the case where the induced fracture merely parallels the natural fracture system. 
3. Induced Fracture Perpendicular to Natural Fracture System

Al though the highest intersection angle for any area in Ohio is 40 degrees, it may be possible in localized areas for the induced fracture to be nomal, at 90 degrees to the natural fracture system.

To examine the maximum effect of fracture intersection angle, the reservoir properties of Area II were used for the Base Case. For the alternative case, the same reservoir properties were used, except that the intersection angle was set at $90^{\circ}$, and to accommodate the 600-foot vertical fracture perpendicular in the 3 by 1 rectangle it was necessary to extend the drainage area to 320 acres. The increased gas recovery is shown below:

Stimulation Well with Large Vertical Fracture

$$
\left(x_{f}=600^{\prime}\right)
$$

10 Years

40 Years
Effect of Alternative Induced Fracture Performance Maximurn Angle Case (Cumulative Recovery, MMcf)
Crosses Natural Frac System T320 Acres/weT1 Angle 900) $\frac{\text { Frac System }}{\text { T160 Acres/We }}$ Angle 100) 


\section{NON-INTERSECTION OF NATURAL. FRACTURE SYSTEM}

The analysis shows that the gas recovery and initial production rate will be decreased greatly even if only a small "skin" effect remains between the extended wellbore and the natural fracture system.

The sensitivity case assumes a wellbore in the center of a widely-spaced, natural fracture system, as displayed in Exhibit 19. In this case, where the distance from the natural fracture system to the edge of the stimulated area is only five feet, and the matrix permeability is low, $10^{-5}$ md (as used in this study), there is virtually no gas production. As Exhibit 20 shows, the permeability in the shale matrix must exceed $0.01 \mathrm{md}$ to have attractive gas flow rates when the stimulation method fails to fully contact the natural fracture system.

\section{ALTERNATIVE PATTERN SHAPE}

A preliminary analysis indicated that a rectangular drainage pattern is more efficient in recovering gas than a square pattern in anisotropic permeability regions. However, this elongated drilling pattern may not always be possible due to existing wells or other constraints in the area.

This sensitivity analysis examines the cumulative gas recovery for three stimulation technologies (borehole shooting, a large radial stimulation, and a large vertical fracture) over three drainage shapes (a square, a 3 by 1 rectangle, and a 6 by 1 rectangle), for Area II which exhibits a pemeability anisotropy ratio of $6: 1$ and a fracture intersection angle of 10 degrees.

The analysis shows that when borehole shooting is used for well stimulation, the drainage shape has little impact on gas recovery, Table 32. However, for the other two stimulation techniques, recovery efficiency is improved by 5 to 10 percent by using alternatives to the traditional square pattern. The analysis shows that the most efficient drainage shape is a rectangle of about 3 by 1, al though the optimum dimensions will depend 


\section{Exhibit 19}

ILLUSTRATION OF MATRIX SKIN

FOR WIDELY SPACED NATURAL FRACTURES

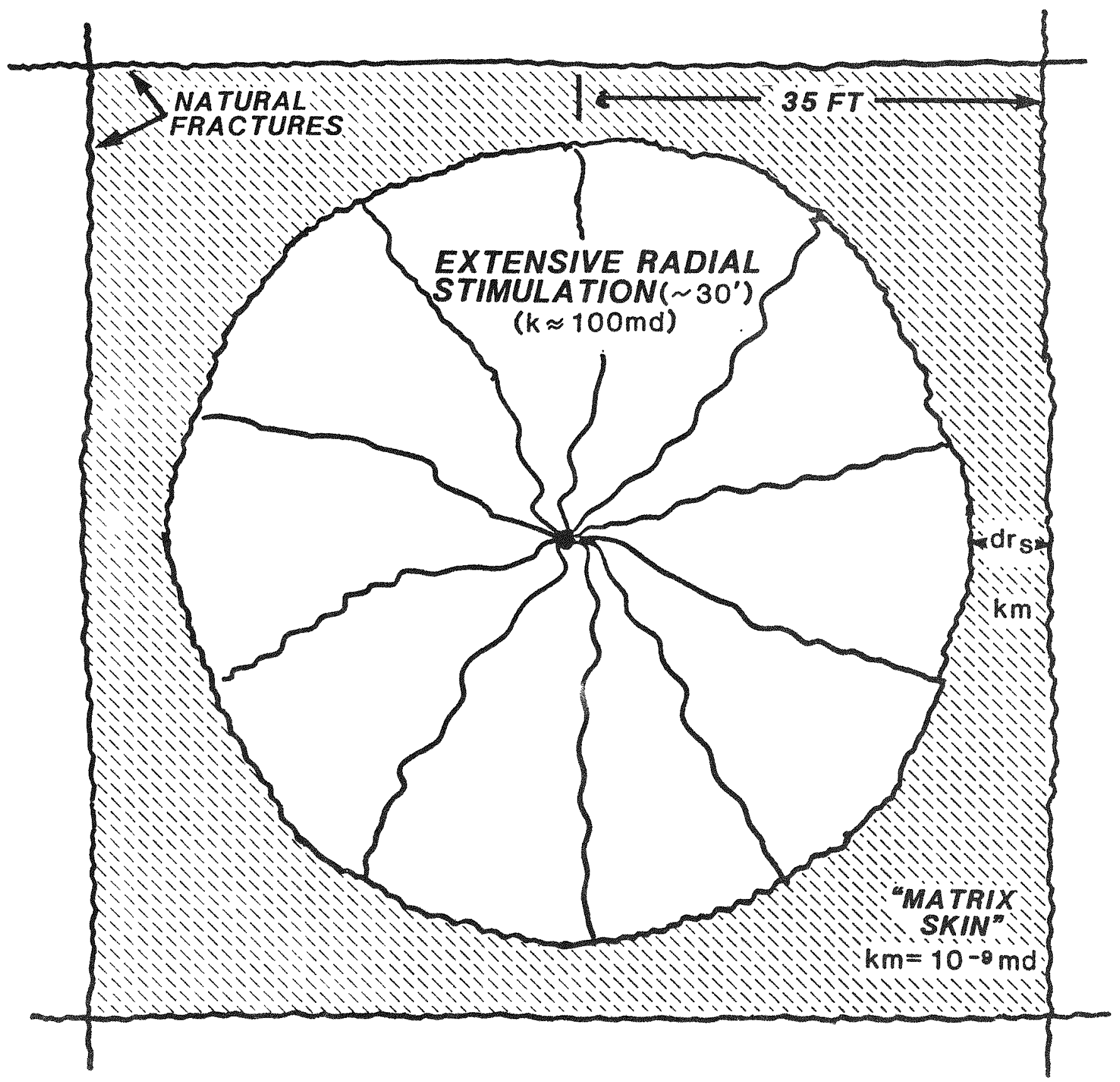


Exhibit 20

MATRIX SKIN VERSUS PRODUCTION

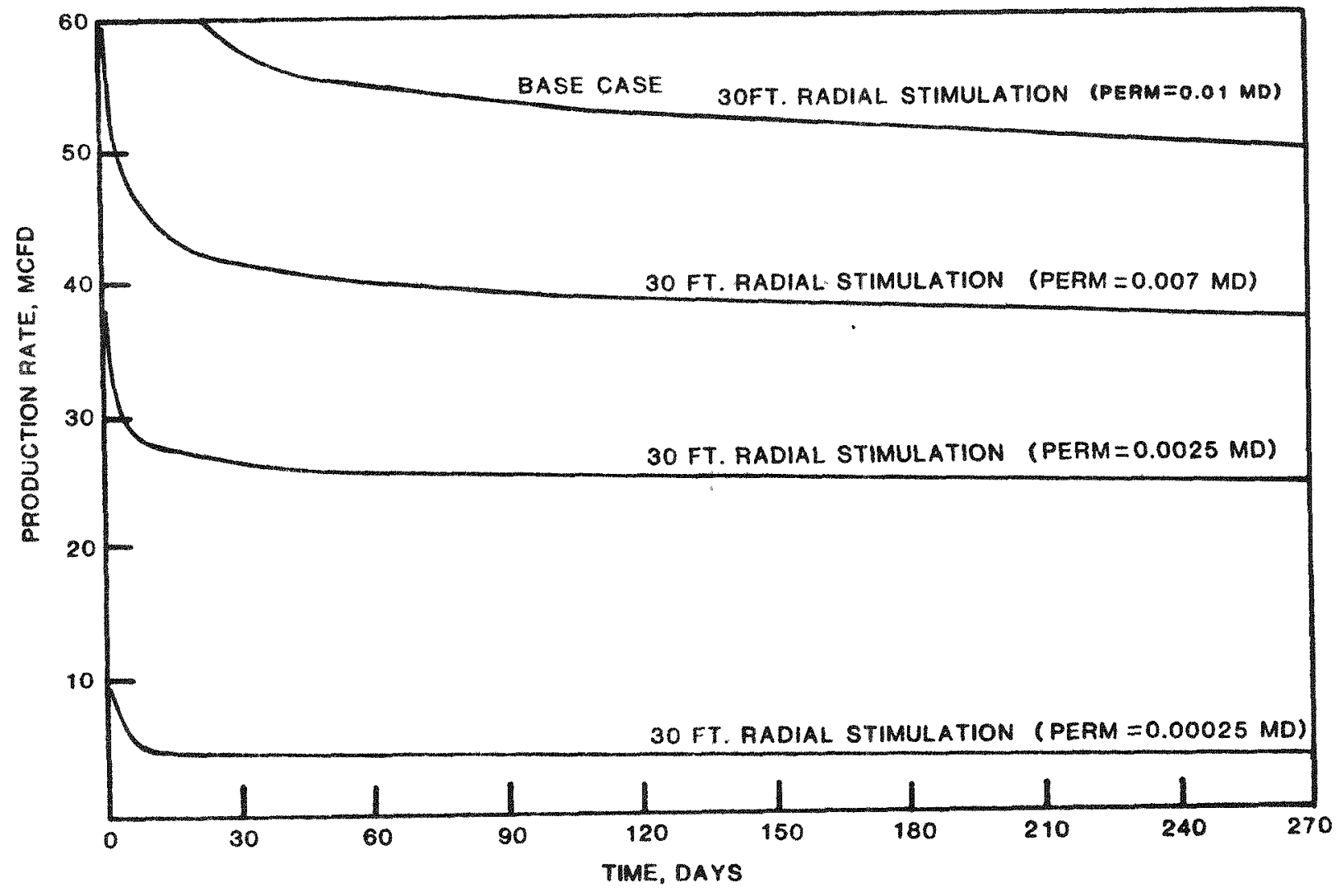


upon the stimulation technique used, drainage pattern size, and the permeability anisotropy in the region. Further study is required to determine the most optimal drainage pattern shape under the large variety of geological variables and well stimulation practices present for the Devonian shale.

TABLE 32

SELECTION OF DRAINAGE PATTERN SHAPE

AREA II

Cumulative Gas Recovery

From Alternative Patterns

Stimulation Technique Square Pattern 3x Pattern 6x Pattern (MMCF) (Mincf) (Micf)

Borehole Shooting

10 Years

63

63

63

40 Years

206

206

206

Large Radial Stimulation

$$
\left(r_{w}=60^{\prime}\right)
$$

10 Years

113

119

114

40 Years

309

324

311

Large Vertical Fracture

$$
\left(x_{f}=600^{\prime}\right)
$$

10 Years

172

190

180

40 Years

402

434

414 
$-99-$

E. COPRODUCTION WITH OIL BEARING SHALE

In several areas, some intervals within the Upper Devonian have been considered as a potential source of oil. Recent drilling has resulted in several wells initially producing high volumes of oil. The coproduction of oil with gas from the Devonian could result in wells paying out in less than a year. In these instances a much smaller drilling pattern, on the order of 40 acres, may be justified. Potential oil producing areas are shown on Exhibit 21 reproduced from the Mound Report. 
Exhibit 21

\section{OVERALL OIL SOURCE ROCK POTENTIAL}

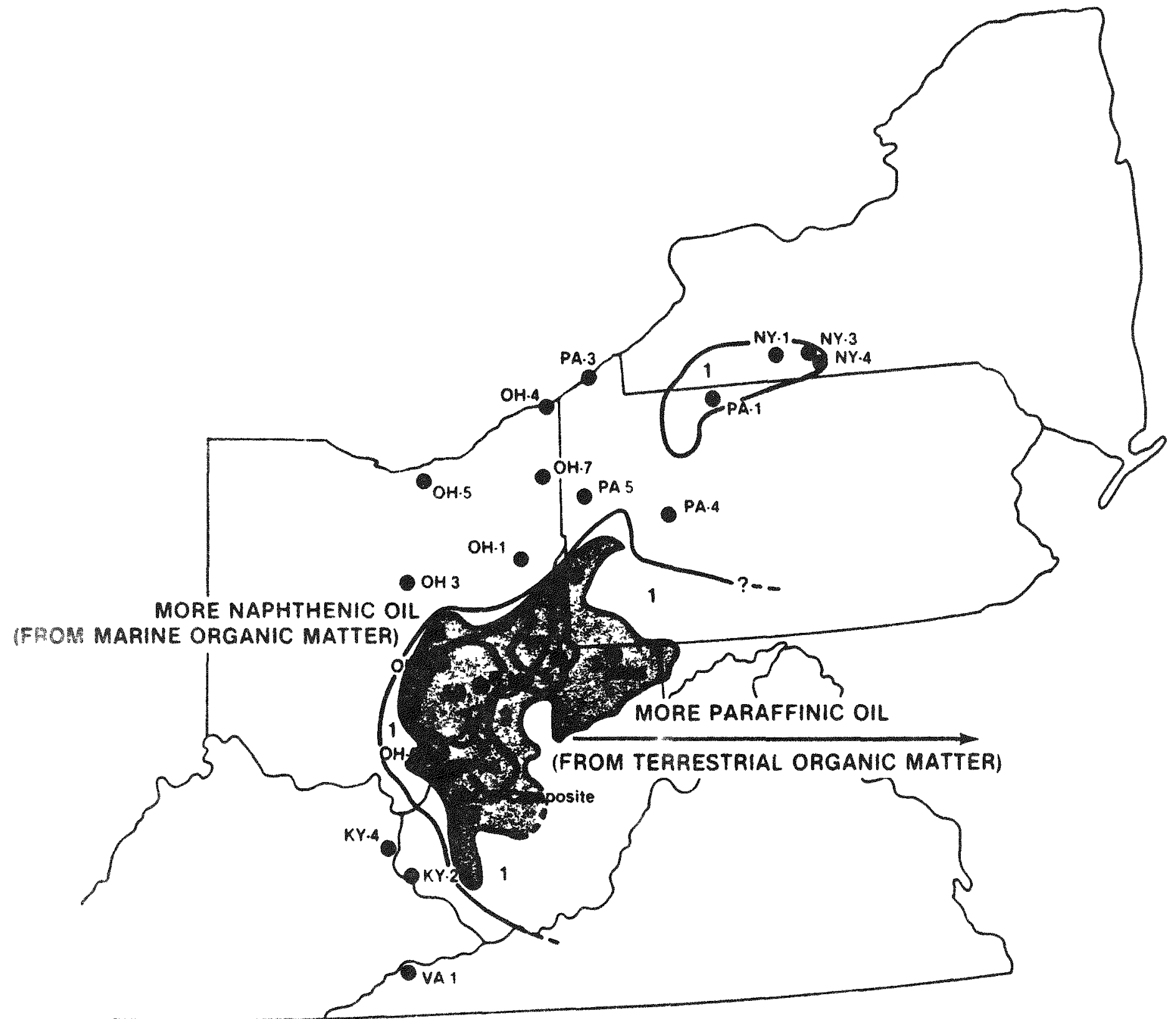

TENN.9

MUES

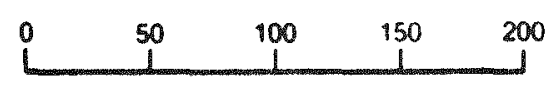

1.GOOD POSSIBILITY OF OIL FROM ONE INTERVAL

10. EXCELLENT POSSIBILITY OF OIL FROM SEVERAL INTERVALS

\section{APPALACHIAN BASIN STUDY AREA}




\section{REFERENCES}

1. Resource and Exploration As sessment of the $0 i 7$ and Gas Potential in the Devonian Gas Shales of the Appalachian Basin (Mound Lab) 1982 (DOE/DP/0053-1125.

2. Analysis of Devonian Shales in the Appalachian Basin (Cliffs Minerals) 1982 (DOE/MC/74693-352,353).

3. Modeling of Devonian Shale Gas Reservoir Performance (SAI) 1979 (DOE/MC/08216-1354).

4. Fractured Shale Gas Reservoir Perfomance Study--An Offset Well Interference Field Test (DOE/METC) 1982 (SPE 11224).

5. Analyses of Devonian Shale Multiwell Interference Tests in Meigs Co., Dhio (SAI) 1982 (DOE/MC/16283-1155).

6. SPE Symposium on Low Permeability Reservoirs, Experimental Evaluation of Fracturing Fluid Interaction With Tight Reservoir Rocks and Propped Fractures (Terra Tek) 1979.

7. Stress Ratio/Structure Map of the Appalachian Basin (METC) 1981 (DOE/METC).

8. Hydraulic Fracturing Experiments in Devonian Shale and Pre-Fractured Hydrostone (SAI) 1981 (DOE/MC/08216-1331).

9. Comparative Analysis of Stimulations in the Eastern Gas Shales (METC) 1981 (DOE/METC-145)

10. Well Test Analysis for Devonian Shale Wells (University of Tulsa) 1981 (DOE/MCV/14645).

11. Unconventional Gas Sources-Vol. III, Devonian Shale (National Petroleurn Councill) 1980. 

APPENDIX A

DATA LOCATIONS 



\section{DATA SOURCES}

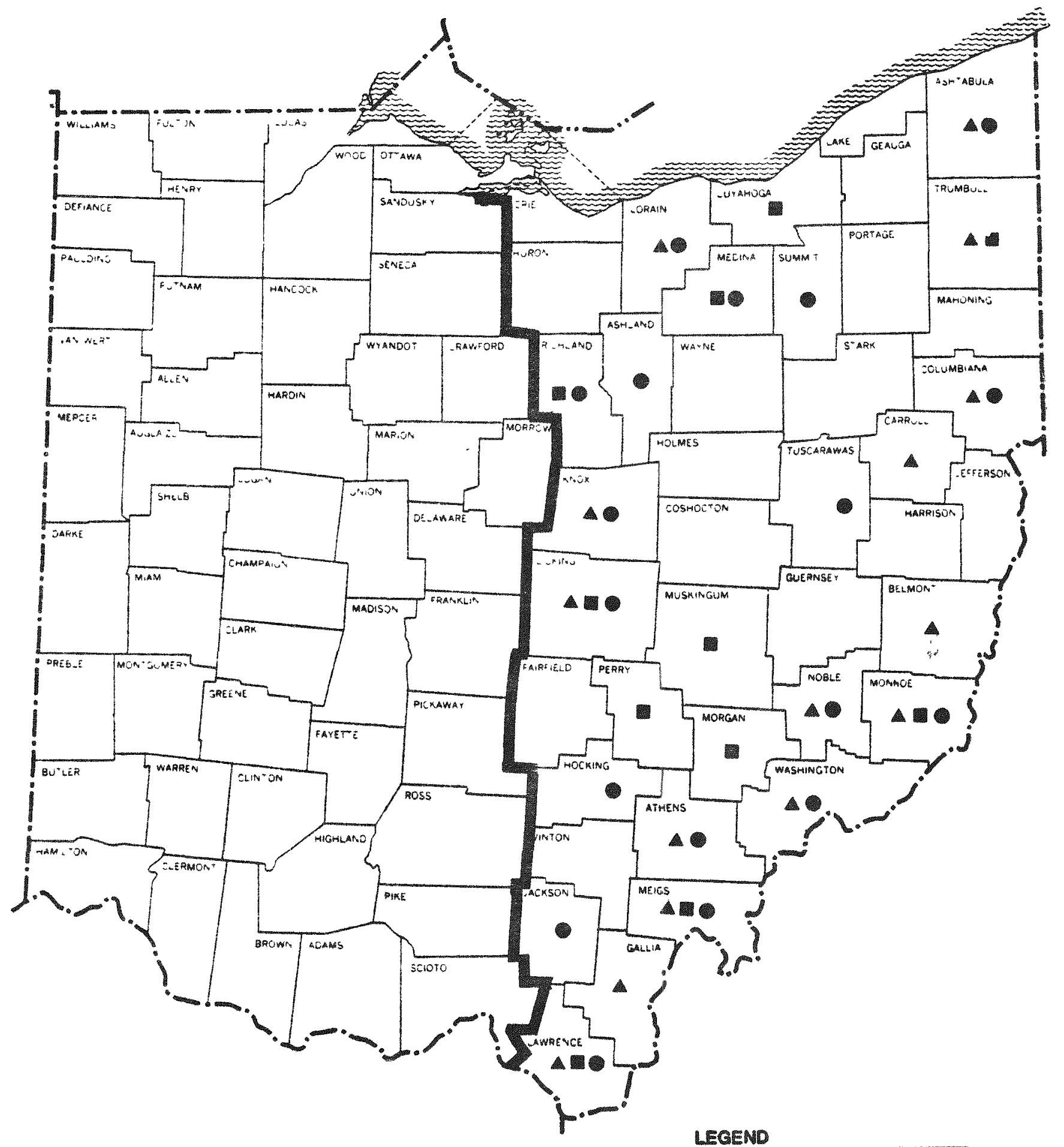

1 INITIAL MOOUCTION

Seste of $\mathrm{x}$ in 


\begin{tabular}{lll}
$\begin{array}{l}\text { Long-Term } \\
\text { Production } \\
\text { LTP }\end{array}$ & $\begin{array}{l}\text { Initial } \\
\text { Production } \\
\text { IP }\end{array}$ & $\begin{array}{l}\text { Rock } \\
\text { Pressure } \\
\text { RP }\end{array}$ \\
\hline
\end{tabular}

\section{ASHLAND COUNTY}

Sullivan

ASHTABULA COUNTY

Geneva

Saybrook

ATHENS COUNTY

Carthage

Lodi

BELMONT COUNTY

Richland

Somerset

CARROLL COUNTY

Augusta

COLUMBIANA COUNTY

Franklin

CUYAHOGA COUNTY

Middleburg

GALLIA COUNTY

Harrison

HOCKING COUNTY

Ward
0

0

1
3

1
0

$\begin{array}{lll}0 & 0 & 2 \\ 0 & 0 & 3\end{array}$

0

0

2
3

1
0

$\begin{array}{lll}0 & 0 & 3 \\ 0 & 0 & 3\end{array}$

0
0

0
0

$\begin{array}{lll}0 & 0 & 1 \\ 0 & 0 & 1\end{array}$

0

2

0

$\begin{array}{lll}0 & 0 & 2\end{array}$

0

1

1

$\begin{array}{lll}0 & 0 & 2\end{array}$

1

0

0

$\begin{array}{lll}0 & 0 & 1\end{array}$

0

7

0

$\begin{array}{lll}0 & 0 & 7\end{array}$

0

0

1 
NUMBER OF RECORDS BY TOWNSHIP (Cont.)

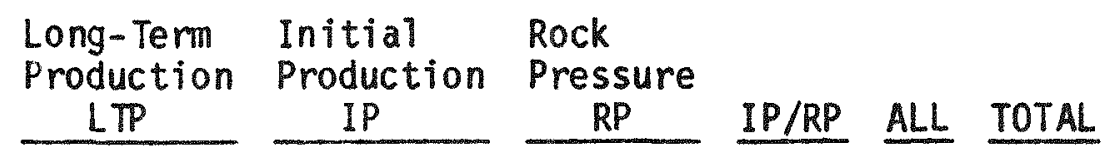

JACKSON COUNTY

Jackson

Milton

KNOX COUNTY

clinton

LANRENCE COUNTY

E1 izabeth

Fayette

Lawrence

Perry

Rome

Union

Upper

windsor

LICKING COUNTY

Bennington

Franklin

Granville

Hanover

Licking

Madison

Newark

Newton

Washington

LORAIN COUNTY

Avon

Columbia

Elyria

Grafton

Henrietta

Pittsfield

Ridgeville
0

0
0

1

$\begin{array}{lll}0 & 0 & 1 \\ 0 & 0 & 1\end{array}$

0

3

1

$\begin{array}{lll}0 & 0 & 4\end{array}$

$\begin{array}{rrrr}1 & 0 & 0 & 1 \\ 0 & 0 & 0 & 1 \\ 0 & 0 & 0 & 1 \\ 1 & 0 & 0 & 2 \\ 4 & 0 & 4 & 8 \\ 6 & 0 & 22 & 28 \\ 0 & 0 & 0 & 1 \\ 21 & 0 & 3 & 25\end{array}$


NUMBER OF RECORDS BY TOWNSHIP (Cont.)

\begin{tabular}{lll}
$\begin{array}{l}\text { Long-Term } \\
\text { Production } \\
\text { LTP }\end{array}$ & $\begin{array}{l}\text { Pnitial } \\
\text { Production } \\
\text { IP }\end{array}$ & $\begin{array}{l}\text { Rock } \\
\text { Pressure } \\
\text { RP }\end{array}$ \\
\hline
\end{tabular}

MEDINA COUNTY

Granger

Hinckley

Liverpool

7
3
0

0
0
0

$\begin{array}{llll}0 & 0 & 0 & 7 \\ 1 & 0 & 0 & 4 \\ 2 & 0 & 0 & 2\end{array}$

MEIGS COUNTY

Chester

Lebanon

olive

orange

Salisburg

Sutton

MONROE COUNTY

Benton

Bethel

center

Jackson

Ma laga

Perry

Seneca

Washington

MORGAN COUNTY

Deerfield

MUSKINGUM COUNTY

Brush Creek

1

0

0

$\begin{array}{lll}0 & 0 & 1\end{array}$

NOBLE COUNTY

Elk

Enoch
12

0

0

0

$\begin{array}{rrrr}1 & 2 & 6 & 21 \\ 1 & 1 & 0 & 4 \\ 2 & 1 & 1 & 9 \\ 14 & 0 & 0 & 15 \\ 0 & 0 & 0 & 1 \\ 1 & 0 & 1 & 7\end{array}$

0
0
0
0
0
7
0
0

$\begin{array}{llll}0 & 0 & 0 & 4 \\ 0 & 0 & 0 & 1 \\ 0 & 0 & 0 & 1 \\ 0 & 0 & 0 & 1 \\ 1 & 0 & 0 & 4 \\ 0 & 0 & 0 & 8 \\ 0 & 0 & 0 & 1 \\ 1 & 1 & 0 & 7\end{array}$

1

0

$\begin{array}{llll}0 & 0 & 0 & 1\end{array}$ 
NUMBER OF RECORDS BY TOWNSHIP (Cont.)

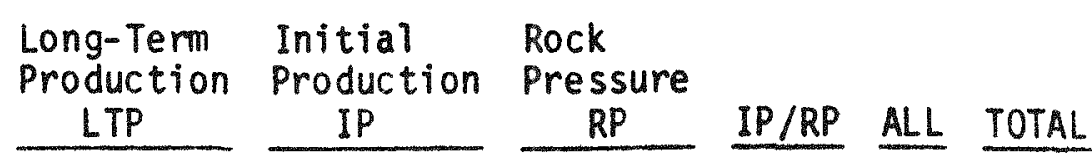

PERRY COUNTY

Monroe

1

0

0

$0 \quad 01$

RICHLAND COUNTY

Holmes

Jackson

Wa shington

SUMMIT COUNTY

Twinsburg

TRUMBULL COUNTY

Athens

TUSCARAWAS COUNTY

Mill

VINTON COUNTY

Elk

WASHINGTON COUNTY

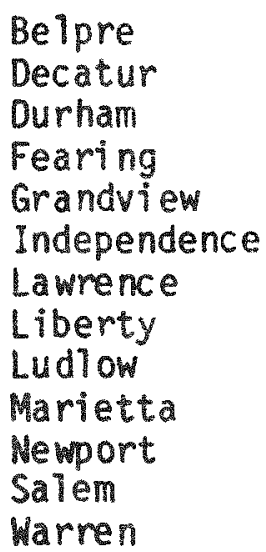

1
0
0

0

0

0
2
2

$\begin{array}{lll}0 & 0 & 1 \\ 0 & 0 & 2 \\ 0 & 0 & 2\end{array}$

0

0

3

$0 \quad 0$

3

11

0

$0 \quad 0$

12

I

0

0

1

$\begin{array}{lll}0 & 0\end{array}$

0

0

2002

$\begin{array}{lr}0 & 3 \\ 0 & 1 \\ 0 & 1 \\ 0 & 0 \\ 0 & 16 \\ 0 & 6 \\ 0 & 5 \\ 0 & 7 \\ 0 & 9 \\ 0 & 3 \\ 0 & 12 \\ 0 & 1 \\ 0 & 3\end{array}$

1
0
0
1
1
0
0
0
1
0
1
0
0

$\begin{array}{rrr}0 & 0 & 4 \\ 0 & 0 & 1 \\ 0 & 0 & 1 \\ 0 & 0 & 1 \\ 0 & 0 & 17 \\ 0 & 0 & 6 \\ 0 & 0 & 5 \\ 0 & 0 & 7 \\ 0 & 0 & 10 \\ 0 & 0 & 3 \\ 0 & 0 & 13 \\ 0 & 0 & 1 \\ 0 & 0 & 3\end{array}$


A-6

APPENDIX B

EGSP CORE WELL DESCRIPTIONS AND LOCATIONS 
DETAILED DESCRIPTION OF EGSP APPALACHIAN BASIN CORE WELL LOCATIONS

\begin{tabular}{|c|c|c|c|c|}
\hline No. & Mound Well & Well Name & State & County \\
\hline 1 & 7239 & $\begin{array}{l}\text { Kentucky-West Virginia Gas Co./ } \\
\text { Nicholas Combs } \# 7239\end{array}$ & Kentucky & Perry \\
\hline 2 & $K Y-2$ & $\begin{array}{l}\text { Columbia Gas Transmission Corp./ } \\
\text { Columbia Gas \#20336 }\end{array}$ & Kentucky & Martin \\
\hline 3 & $K Y-4$ & $\begin{array}{l}\text { Ashland } 0 \text { il Co./ } \\
\text { Skaggs-Kelley Unit \#3-RS }\end{array}$ & Kentucky & Johnson \\
\hline 4 & $N Y-1$ & $\begin{array}{l}\text { National Fuel Gas Supply Corp.l } \\
\text { \#5213 }(\text { (Jo) EGSP NY\#1 }\end{array}$ & New York & Allegany \\
\hline 5 & $N Y-3$ & $\begin{array}{l}\text { Arlington Exploration Co.l } \\
\text { Ambrose Scudder Unit No. } 1\end{array}$ & New York & Steuben \\
\hline 6 & $N Y-4$ & $\begin{array}{l}\text { Arlington Exploration Co.l } \\
\text { Valley Vista View, Inc. \#1 }\end{array}$ & New York & Steuben \\
\hline 7 & $N Y-5$ & Gustavson \& Associates & New York & Steuben \\
\hline 8 & $\mathrm{OH}-1$ & $\begin{array}{l}\text { Canton Oil \& Gas CO.l } \\
\text { Glen-Gery \#-74S }\end{array}$ & Onio & Carroll \\
\hline 9 & $R-109$ & $\begin{array}{l}\text { River Gas Company/ } \\
\text { Florence L. House \#R-109 } \\
(\mathrm{OH}-2)\end{array}$ & Ohio & Washington \\
\hline
\end{tabular}




\begin{tabular}{|c|c|c|c|c|}
\hline No. & Mound Well & Well Name & State & County \\
\hline 10 & $\mathrm{OH}-3$ & $\begin{array}{l}\text { Thurlow Weed \& Associates/ } \\
\text { Louise Beckholt \#1 }\end{array}$ & Onio & Knox \\
\hline 11 & $\mathrm{OH}-4$ & $\begin{array}{l}\text { Mansanto Research Corp./Bessemer } \\
\text { and Lake Erie Railroad Co. } \# 3\end{array}$ & Onio & Ashtabula \\
\hline 12 & $\mathrm{OH}-5$ & $\begin{array}{l}\text { Columbia Gas Transmission Corp./ } \\
\text { D.M. Wakefield \#10148-7 }\end{array}$ & Onio & Lorain \\
\hline 13 & $\mathrm{OH}-6-1$ & $\begin{array}{l}\text { Mitchell Energy Corp./\#1-5 } \\
\text { Carpenter }\end{array}$ & Onio & Gallia \\
\hline 14 & $\mathrm{OH}-6-2$ & Mitchell Energy Corp. & Onio & Gallia \\
\hline 15 & $O H-6-3$ & $\begin{array}{l}\text { Mitchell Energy Corp./L. McCombs } \\
\# 1-6\end{array}$ & Onio & Gallia \\
\hline 16 & $\mathrm{OH}-6-4$ & $\begin{array}{l}\text { Mitchell Energy Corp./\#1-8 } \\
\text { straight }\end{array}$ & Onio & Gallia \\
\hline 17 & OH-6-5 & $\begin{array}{l}\text { Mitchell Energy Corp./ Carter } \\
=1-9\end{array}$ & Ohio & Gallia \\
\hline 18 & $\mathrm{OH}-7$ & $\begin{array}{l}\text { Columbia Gas Transmission Corp./ } \\
\text { Anna Meleski } \# 20143\end{array}$ & Onio & Trumbull \\
\hline 19 & $\mathrm{OH}-8$ & $\begin{array}{l}\text { Donohue, Austey \& Morrill/ } \\
\text { Schockling \# } 1\end{array}$ & Onio & Noble \\
\hline
\end{tabular}


DETAILED DESCRIPTION OF EGSP APPALACHIAN BASIN CORE WELL LOCATIONS

\begin{tabular}{|c|c|c|c|c|}
\hline No. & Mound Well & Well Name & State & County \\
\hline 20 & $\mathrm{OH}-9$ & $\begin{array}{l}\text { Gruy Federal, Inc./DOE/Columbia } \\
\text { Gas Co. \#10056-A }\end{array}$ & Onio & Meigs \\
\hline 21 & PA-1 & $\begin{array}{l}\text { Minard Run } 0 i 1 \text { Co.l } \\
\text { Minard Run Exploration \#1 }\end{array}$ & Pennsyivania & Mckean \\
\hline 22 & PA-2 & $\begin{array}{l}\text { C.E. Power Systems/ } \\
\text { C.E. Power Systems \#1 }\end{array}$ & Pennsyivania & Allegheny \\
\hline 23 & PA-3 & $\begin{array}{l}\text { Monsanto Research Corp. } \\
\text { Pennsyivania DER/Presque } \\
\text { Isle State Park \#I }\end{array}$ & Pennsylvania & Erie \\
\hline 24 & PA-4 & $\begin{array}{l}\text { Gruy Federal, Inc./DOE/Gien } \\
\text { McCall \#5 }\end{array}$ & Pennsylvania & Indiana \\
\hline
\end{tabular}

25 PA-5 Peoples Natural Gas/C.

Pennsylvania Lawrence Sokevitz \#1

26 TENN-9 Gruy Federai, Inc./DOE/ Tennessee Grainger Gruy Federal \#1

27 Va-1 Columbia Gas Transmission Virgini Wise Corp./ Penn Va. Corp. Farm Well \#20338

2811940 Consolidated Gas Supply West Virginia Jackson Corp./L.A. Bales 11940 
DETAILED DESCRIPTION OF EGSP APPALACHIAN BASIN CORE WELL LOCATIONS

No. Mound Well

Well Name

State County

29 WV-5 Reel Drilling Co./ D/K

West Virginia Mason

Farm \#3

30 WV-6 U.S. Dept of Energy

West Virginia Monongalia

MERC \#1

31 WV-7 Mobay Chemical Corp./

West Virginia Wetzel

H. Emch \& A. Pyles Unit \#1 


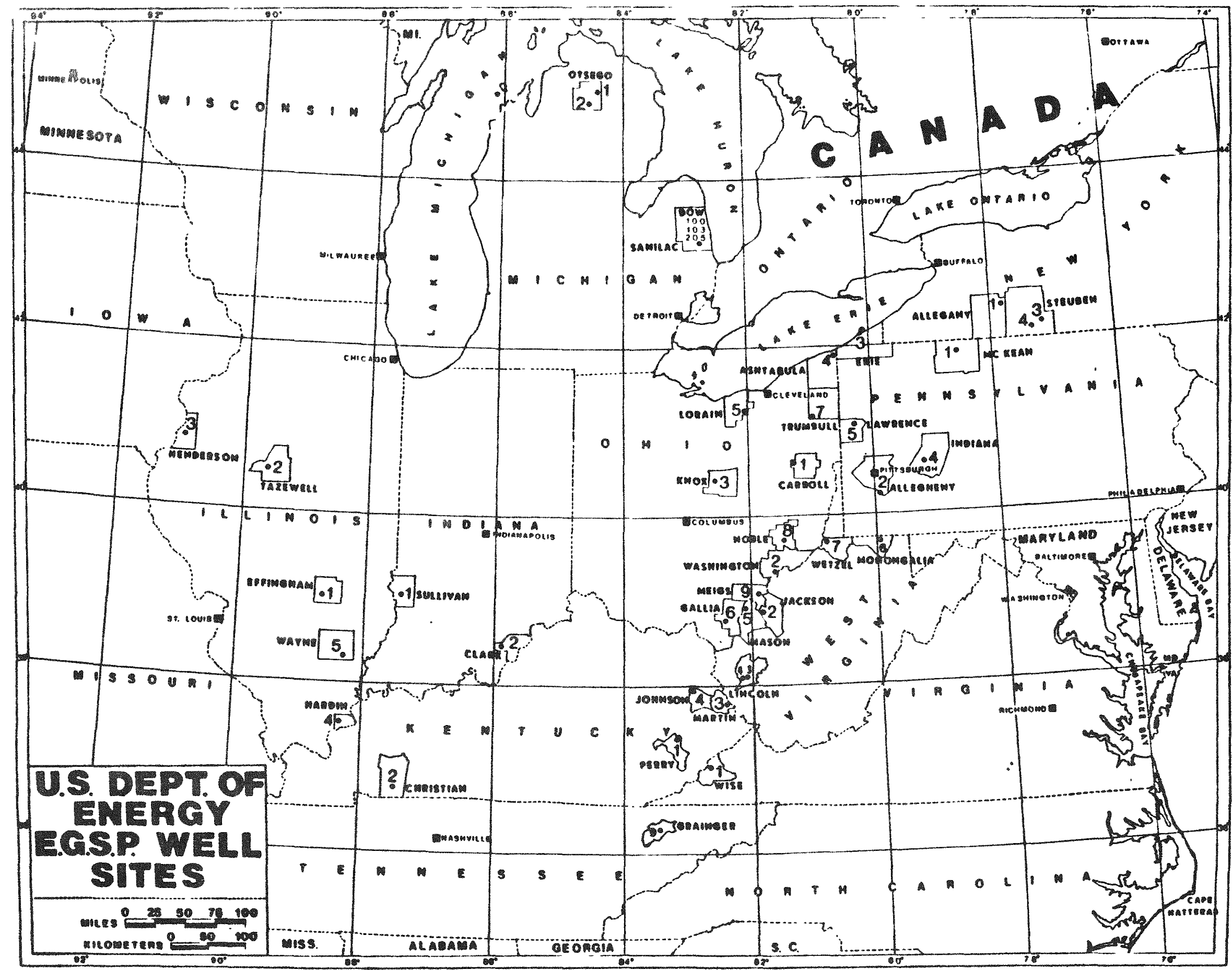


A-12

APPENDIX C

REPRFSENTATIVE WELL SELECTION METHODOLOGY 
Representative wells were identified for those counties where sufficient production data were available to characterize the resource in a statistically meaningful way.

Selection of Representative Wells. The first phase in selecting representative wells was to screen the data base and refine it using the following approach:

- The wells were individually metered.

- Production from shale members was distinguished from other producing horizons.

- High, average and low producers were included.

- Production data for a minimum of four weeks had to be available for a county to be included in the selection process.

The purpose of this screening was to ensure that the well records were representative and adequate to characterize the resource.

This procedure limited the counties with long-tem well data to three: Lawrence, Licking, and Meigs.

The second phase of the selection process to identify representative wells for each county used the process outlined on the following Exhibit. The steps for this process are discussed in detail below:

Step 1: To properly assess shale production, the wells used for history matching must have produced for at least 15 years. Wells producing for less than 15 years were eliminated from the selection set. 
PROCESS FOR SELECTING REPRESENTATIVE WELLS

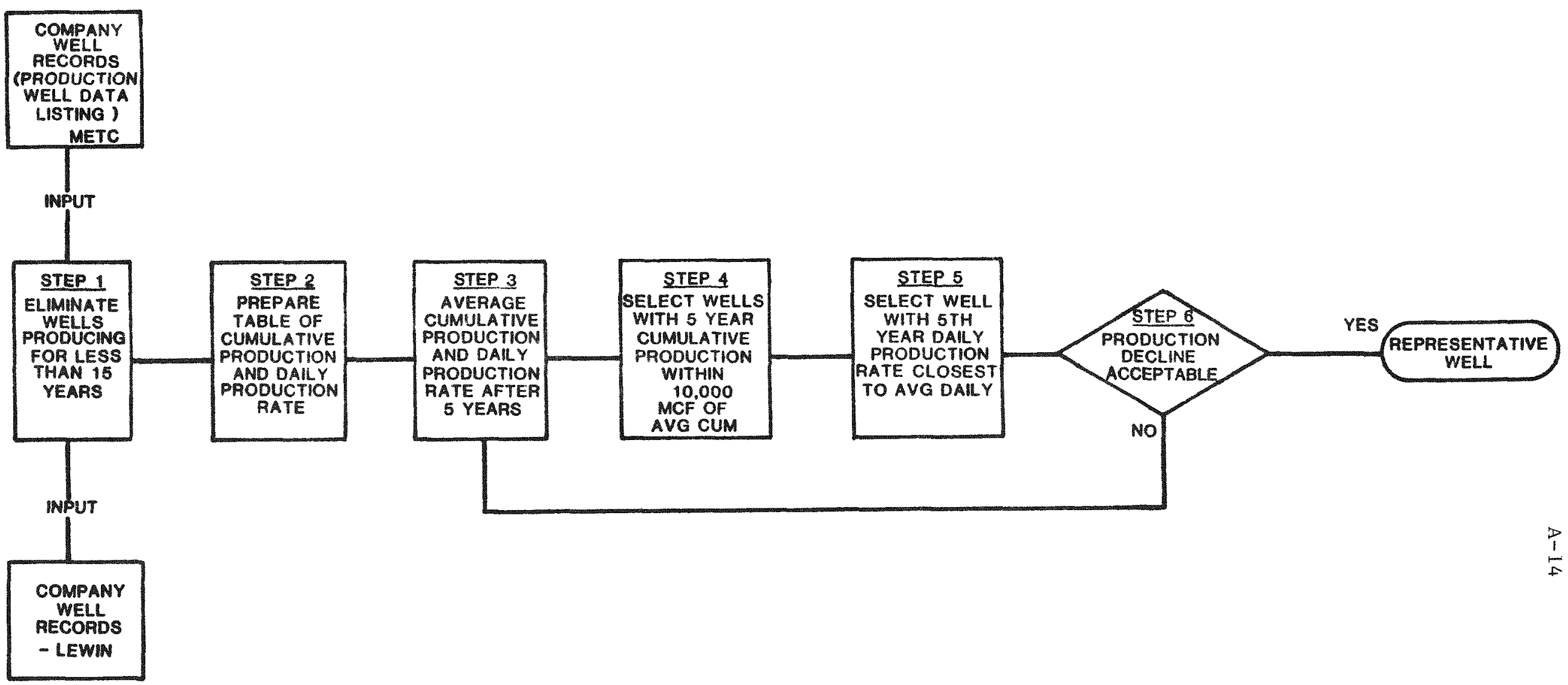


Step 2: A production table by well was prepared for each county. This table consisted of identifying the daily production rate for the well during its fifth full year on line along with cumulative production. If a well did not produce for a complete year initially, the initial production was not utilized in establishing the daily rate (Mcf/D) for the fifth year of production. In addition, the cumulative production (MMcf) was adjusted to reflect the elimination of the initial production figure.

Step 3: Using the data generated in Step 2, the average cumulative production and average daily production rate after five years were computed for each of these ohio counties.

Step 4: Wells which have a five-year cumulative production within $\pm 10,000$ MCF of the average computed in Step 2 were selected as representative wells.

Step 5: Using the candidate wells identified in Step 3, the well which has a fifth year daily production rate closest to the average computed in Step 2 was selected as the best candidate well.

Step 6: The well identified in the last step was reviewed for production decline. This step constitutes a "test of acceptability." If the production decline was abnormal, the well was eliminated from consideration and the process returned to step 3 . If the production decline was acceptable, the well was selected as the "representative well" for that county. 
$A-16$

APPENDIX D

PRODUCTION DATA REFERENCE 


\section{PRIMARY PARTITIONED AREAS DEVONIAN GAS SHALES OF OHIO}

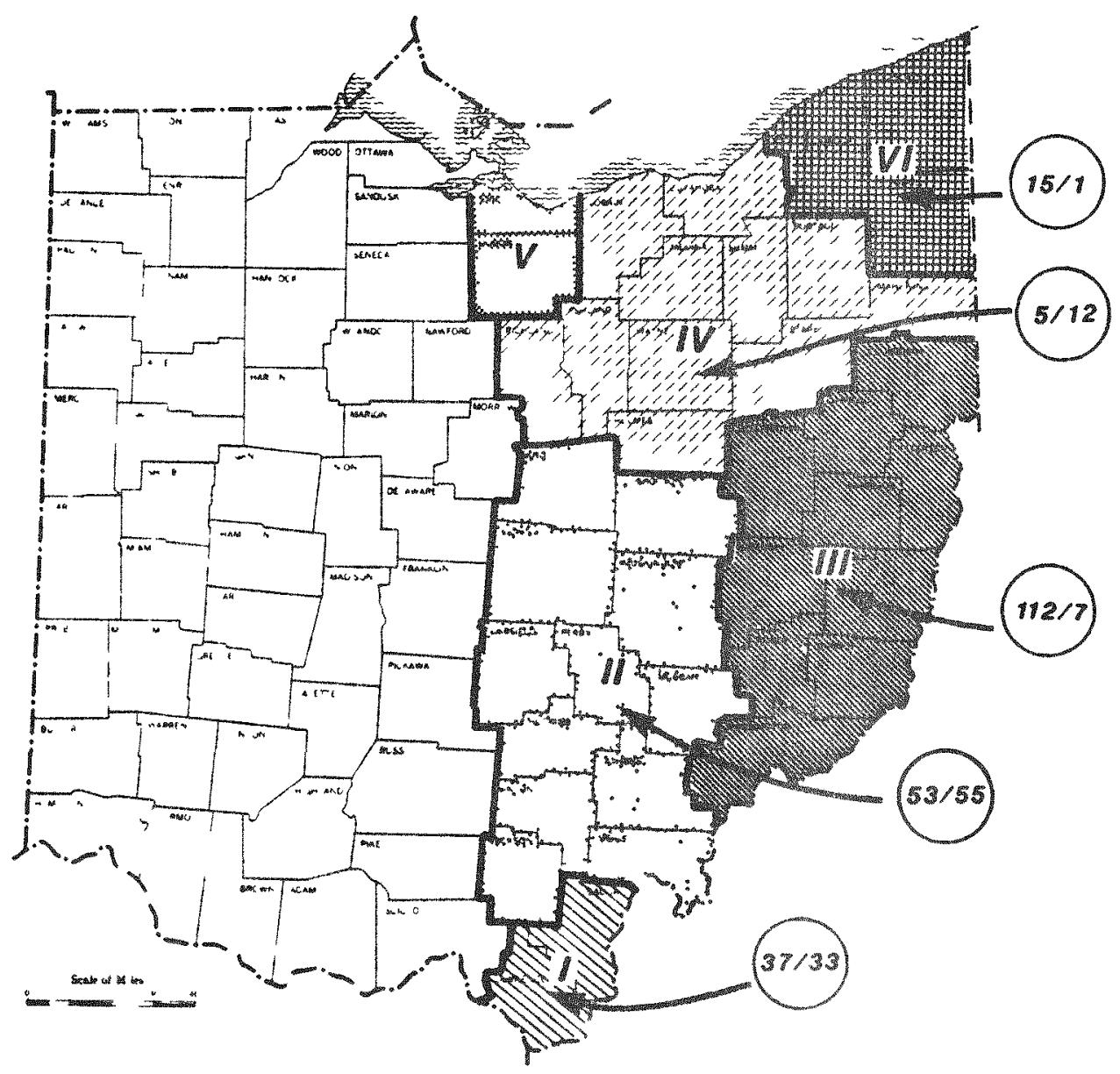

* NUMBER OF OPENFLOW GAS PRODUCTION PECORDS 1 NUMBER OF LONG-TEPA GAS PRODUCTION RECOADS

AVERAGE GEOLOGIC PROPERTIES BY AREA

\begin{tabular}{|c|c|c|c|}
\hline $\begin{array}{c}\text { PARTITIONED } \\
\text { AREA } \\
\end{array}$ & $\begin{array}{l}\text { FPACTUAE } \\
\text { SPACING } \\
\end{array}$ & $\begin{array}{l}\text { PERMEAEULITY } \\
\text { ANISOTFOPY }\end{array}$ & $\begin{array}{l}\text { NTEPSEGTION } \\
\text { ANEE }\end{array}$ \\
\hline & $(1000)$ & (redo) & (c) \\
\hline 1 & 10 & 11 & MA \\
\hline 䇏 & 20 & 61 & 10 \\
\hline III & 20 & i & 20 \\
\hline IV & 20 & 61 & 40 \\
\hline$v$ & 20 & (1) & 40 \\
\hline VI & 20 & 61 & 10 \\
\hline
\end{tabular}




\section{SUMMARY OF OHIO DEVOMIAN SHALE GAS POTENTIAL}

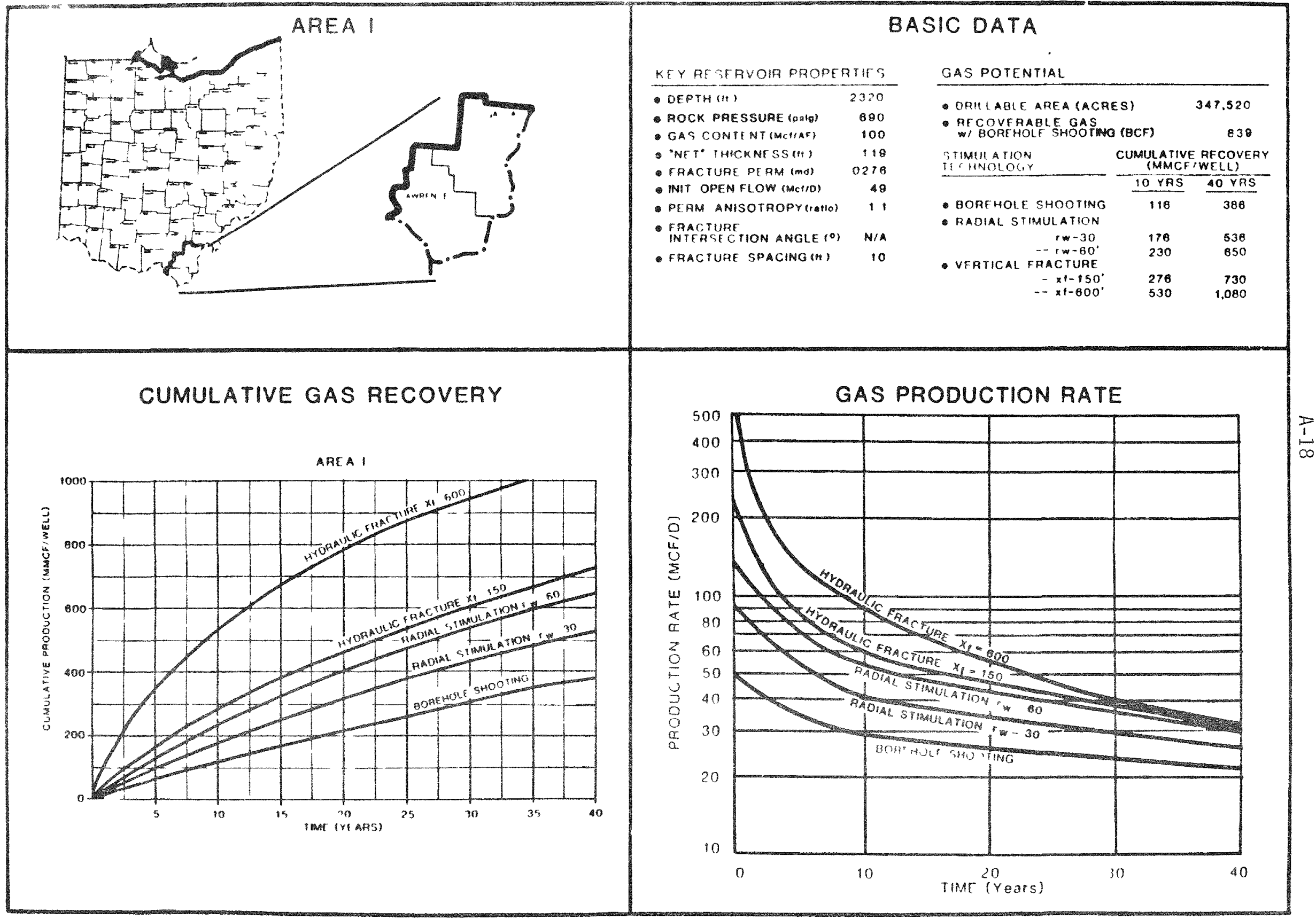


CUMULATIVE GAS RECOVERY BY TYPE OF STIMULATION (MMCF)

(One Well Per 160 Acres)

AREA 1

Stimulation Method

\begin{tabular}{|c|c|c|c|c|c|}
\hline & Borehole & $\begin{array}{l}\text { Small } \\
\text { Radial }\end{array}$ & $\begin{array}{l}\text { Large } \\
\text { Radial } \\
\text { Stimulation }\end{array}$ & $\begin{array}{c}\text { Small } \\
\text { Vertical } \\
\text { Fracture }\end{array}$ & $\begin{array}{l}\text { Large } \\
\text { Vertical } \\
\text { Fracture }\end{array}$ \\
\hline$a r$ & & $\begin{array}{r}\text { Stimulation } \\
r_{W}^{\prime}=30^{\circ}\end{array}$ & $\begin{aligned} & \text { stomulation } \\
& r_{w}^{\prime}=60^{\prime}\end{aligned}$ & $x f=150^{\circ}$ & $\begin{array}{l}\text { Practure } \\
x f=600\end{array}$ \\
\hline
\end{tabular}

$\begin{array}{rrrrrr}1 & 13.8 & 23.4 & 33.5 & 46.5 & 123.4 \\ 5 & 61.3 & 96.3 & 129.3 & 161.3 & 344.1 \\ 10 & 116.1 & 176.5 & 230.1 & 276.4 & 529.7 \\ 20 & 216.2 & 316.2 & 399.3 & 463.6 & 786.8 \\ 40 & 386.4 & 536.1 & 650.4 & 729.8 & 1.080 .0\end{array}$

AREA I

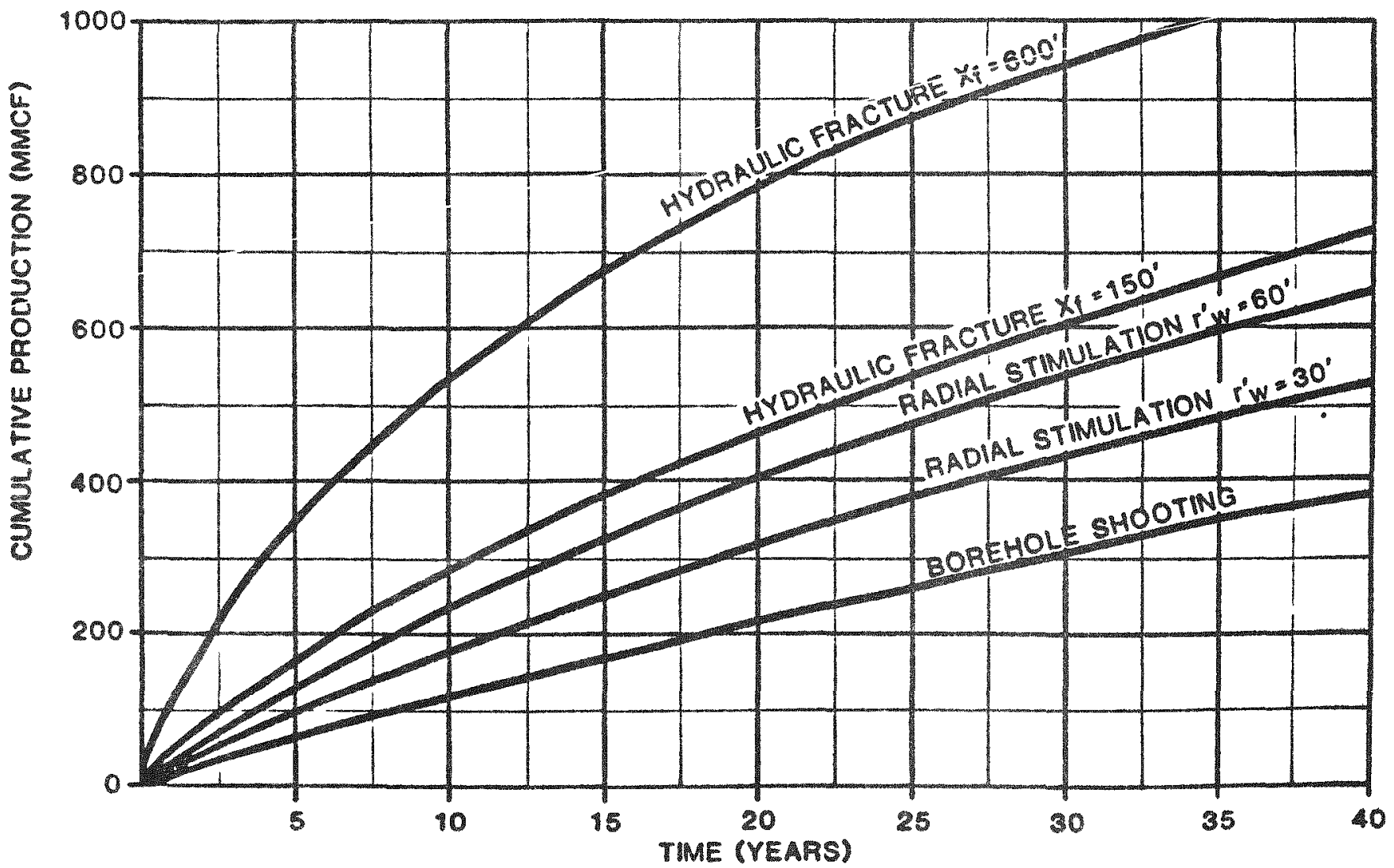


AVERAGE DAILY GAS PRODUCTION BY TYPE OF STIMULATION (MCF/d) AREA I

Stimulation Method

\begin{tabular}{|c|c|c|c|c|}
\hline $\begin{array}{l}\text { Borehole } \\
\text { Shooting }\end{array}$ & $\begin{array}{c}\text { Small } \\
\text { Radial } \\
\text { Stimulation } \\
r^{\prime}{ }^{\prime}=30^{\prime}\end{array}$ & $\begin{array}{c}\text { Large } \\
\text { Radial } \\
\text { Stimulation } \\
r^{\prime} w^{\prime}=60^{\circ}\end{array}$ & $\begin{array}{l}\text { Small } \\
\text { Vertical } \\
\text { Fracture } \\
x f=150^{\circ}\end{array}$ & $\begin{array}{l}\text { Large } \\
\text { Vertical } \\
\text { Fracture } \\
x f=600^{3}\end{array}$ \\
\hline
\end{tabular}

$\begin{array}{rrrrrr}1 & 36 & 58 & 80 & 103 & 238 \\ 5 & 31 & 47 & 60 & 70 & 123 \\ 10 & 29 & 42 & 52 & 59 & 90 \\ 20 & 26 & 35 & 47 & 46 & 57 \\ 40 & 21 & 26 & 29 & 30 & 29\end{array}$

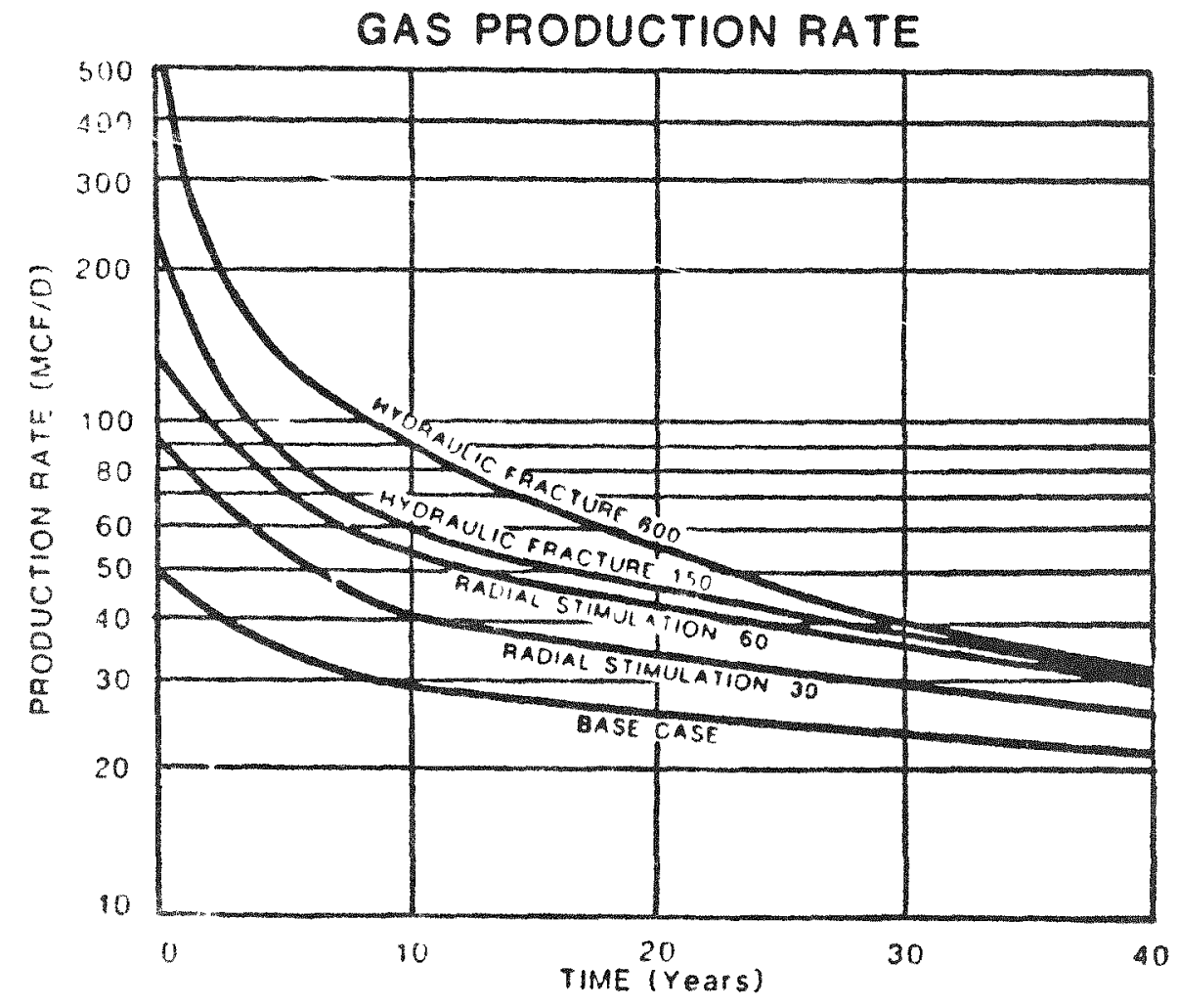


SUMMAPY OF OHIO DEVONIAN SHALE GAS POTENTIAL

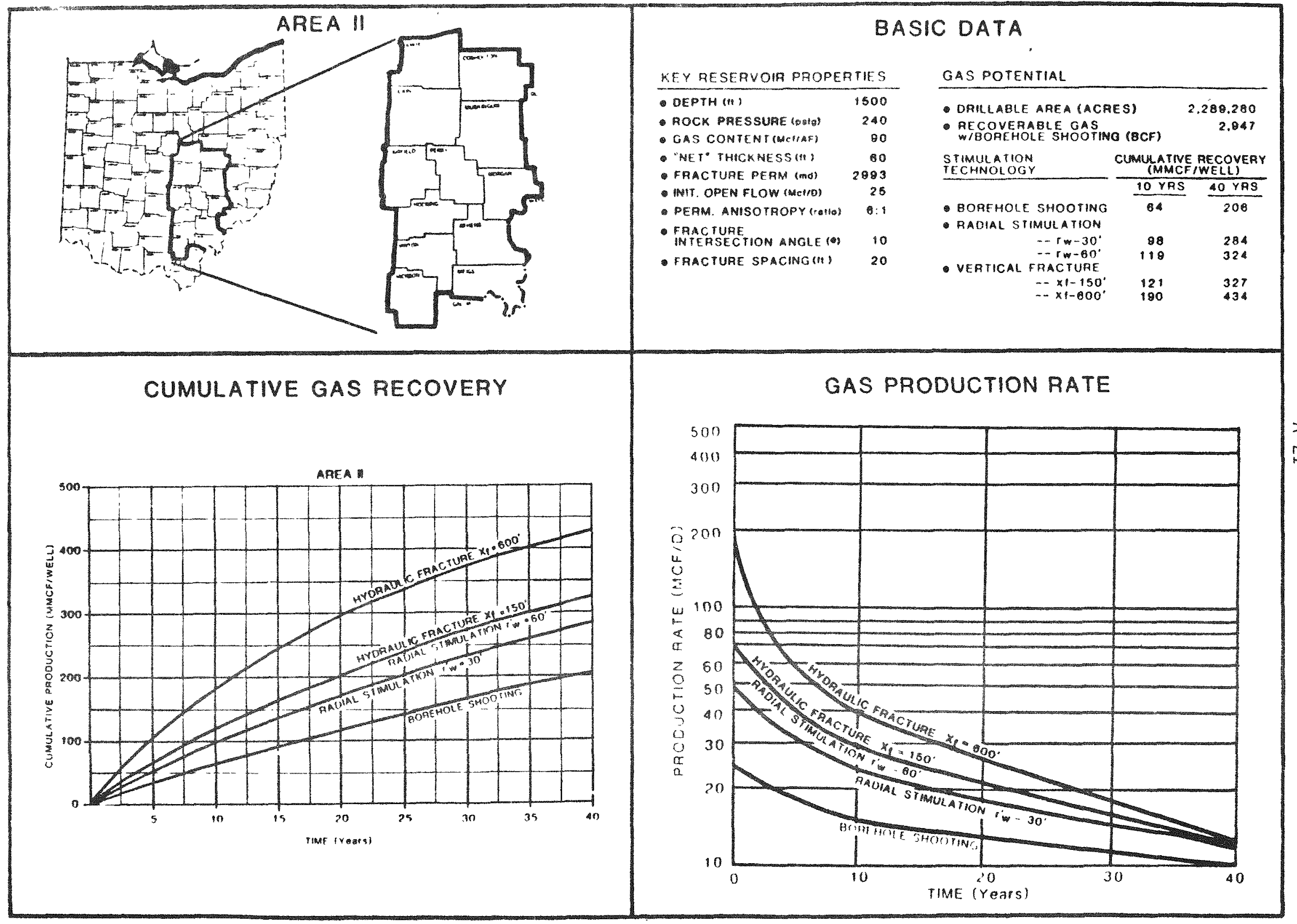




\section{CUMULATIVE GAS RECOVERY BY TYPE OF STIMULATION (MMCP) \\ (One Well Per 160 Acres) \\ AREA II}

\begin{tabular}{|c|c|c|c|c|c|}
\hline \multirow[b]{2}{*}{ Year } & \multicolumn{5}{|c|}{ Stimulation Method } \\
\hline & $\begin{array}{l}\text { Borehole } \\
\text { Shooting }\end{array}$ & $\begin{array}{c}\text { Small } \\
\text { Radial } \\
\text { Stimulation } \\
r_{w}^{\prime}=30^{\prime}\end{array}$ & $\begin{array}{c}\text { Large } \\
\text { Radial } \\
\text { Stimulation } \\
r^{\prime} w=60^{\circ}\end{array}$ & $\begin{array}{l}\text { Small } \\
\text { Vertical } \\
\text { Fracture } \\
x f=150^{\circ}\end{array}$ & $\begin{array}{l}\text { Large } \\
\text { Vertical } \\
\text { Fracture } \\
x+=600^{\circ}\end{array}$ \\
\hline 1 & 7.1 & 11.4 & 14.3 & 14.7 & 26.1 \\
\hline 5 & 33.7 & 52.8 & 65.0 & 66.4 & 110.1 \\
\hline 10 & 64.3 & 98.0 & 118.6 & 120.7 & 189.6 \\
\hline 20 & 118.5 & 173.3 & 204.8 & 207.3 & 302.1 \\
\hline 40 & 206.0 & 283.8 & 324.4 & 326.6 & 433.9 \\
\hline
\end{tabular}

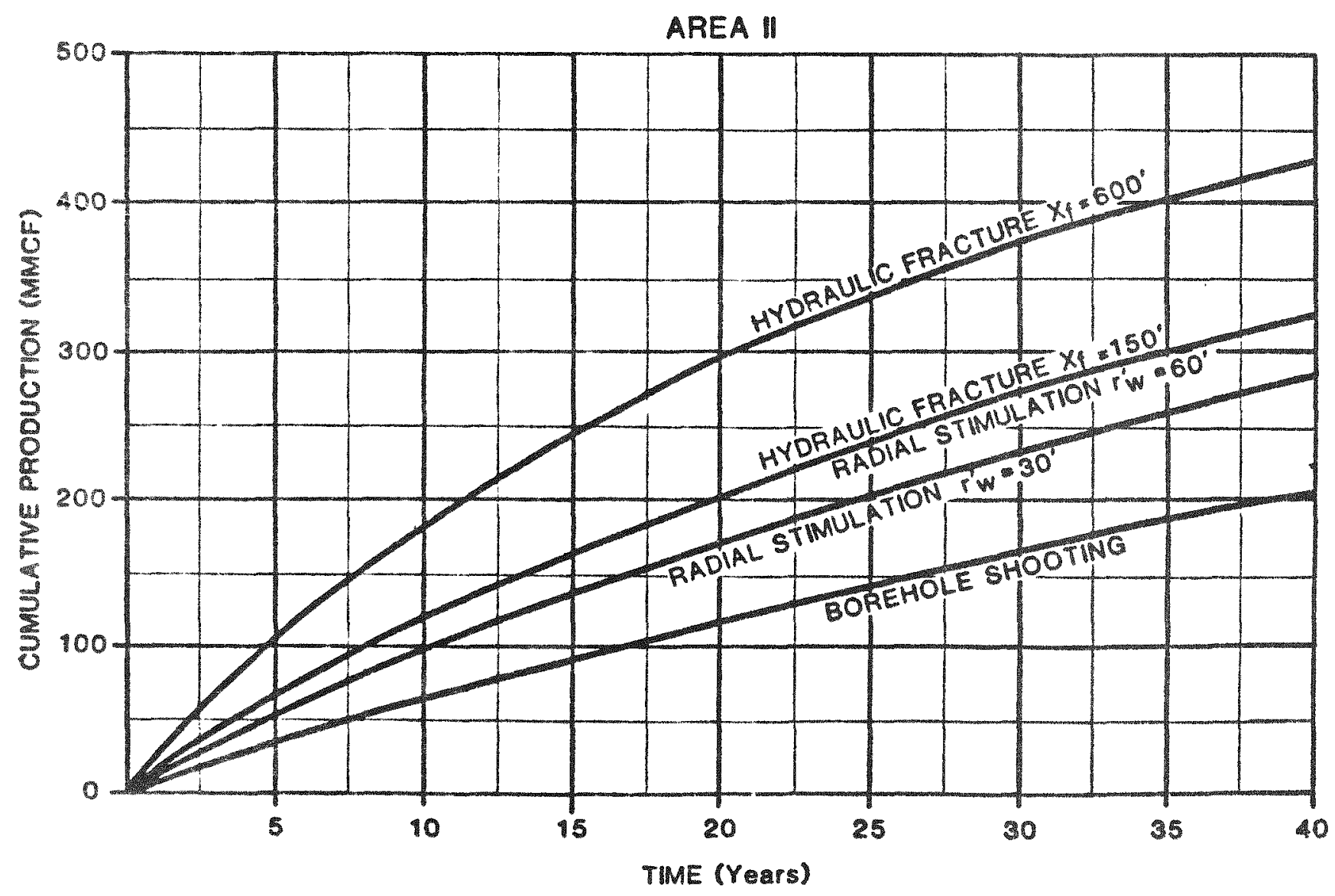


AVERAGE DAILY GAS PRODUCTION BY TYPE OF STIMULATION (MCf/d) AREA II

Stimulation Method

\begin{tabular}{cccccc} 
Year & $\begin{array}{c}\text { Borehole } \\
\text { Shooting }\end{array}$ & $\begin{array}{c}\text { Small } \\
\text { Radial } \\
\text { Stimulation } \\
r^{\prime}=30^{\circ}\end{array}$ & $\begin{array}{c}\text { Large } \\
\text { Radial } \\
\text { Stimulation } \\
r^{\prime}=60^{\circ}\end{array}$ & $\begin{array}{c}\text { Small } \\
\text { Vertical } \\
\text { Fracture } \\
x_{f}=150^{\prime}\end{array}$ & $\begin{array}{c}\text { Large } \\
\text { Fertical } \\
x_{f}=600^{\prime}\end{array}$ \\
\hline 1 & 19 & 31 & 38 & 39 & 68 \\
5 & 18 & 27 & 33 & 33 & 51 \\
10 & 16 & 23 & 28 & 28 & 39 \\
20 & 14 & 19 & 21 & 21 & 25 \\
40 & 10 & 13 & 13 & 13 & 13
\end{tabular}

GAS PRODUCTION RATE

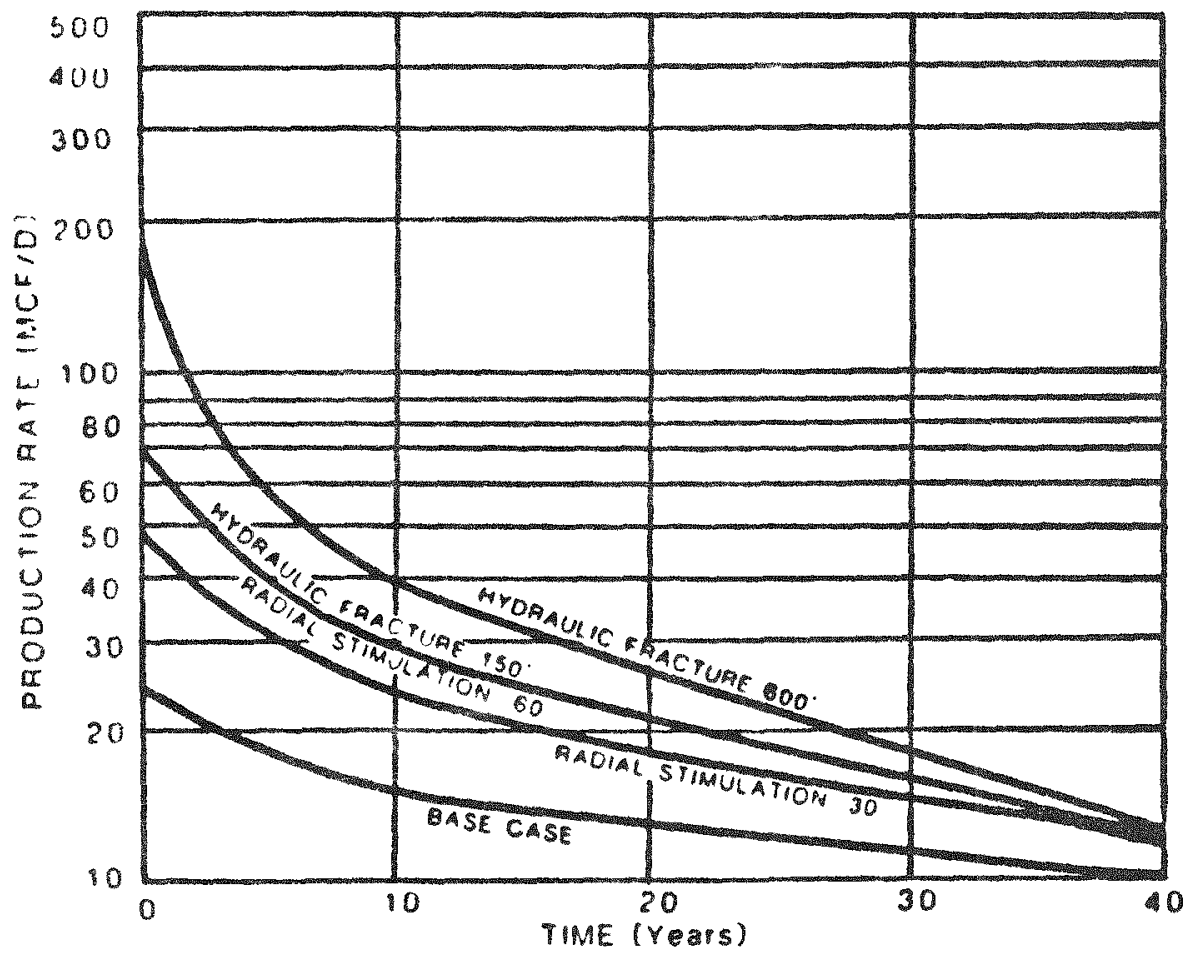


SUMMARY OF OHO DEVONIAM SHALE GAS POTENTIAL

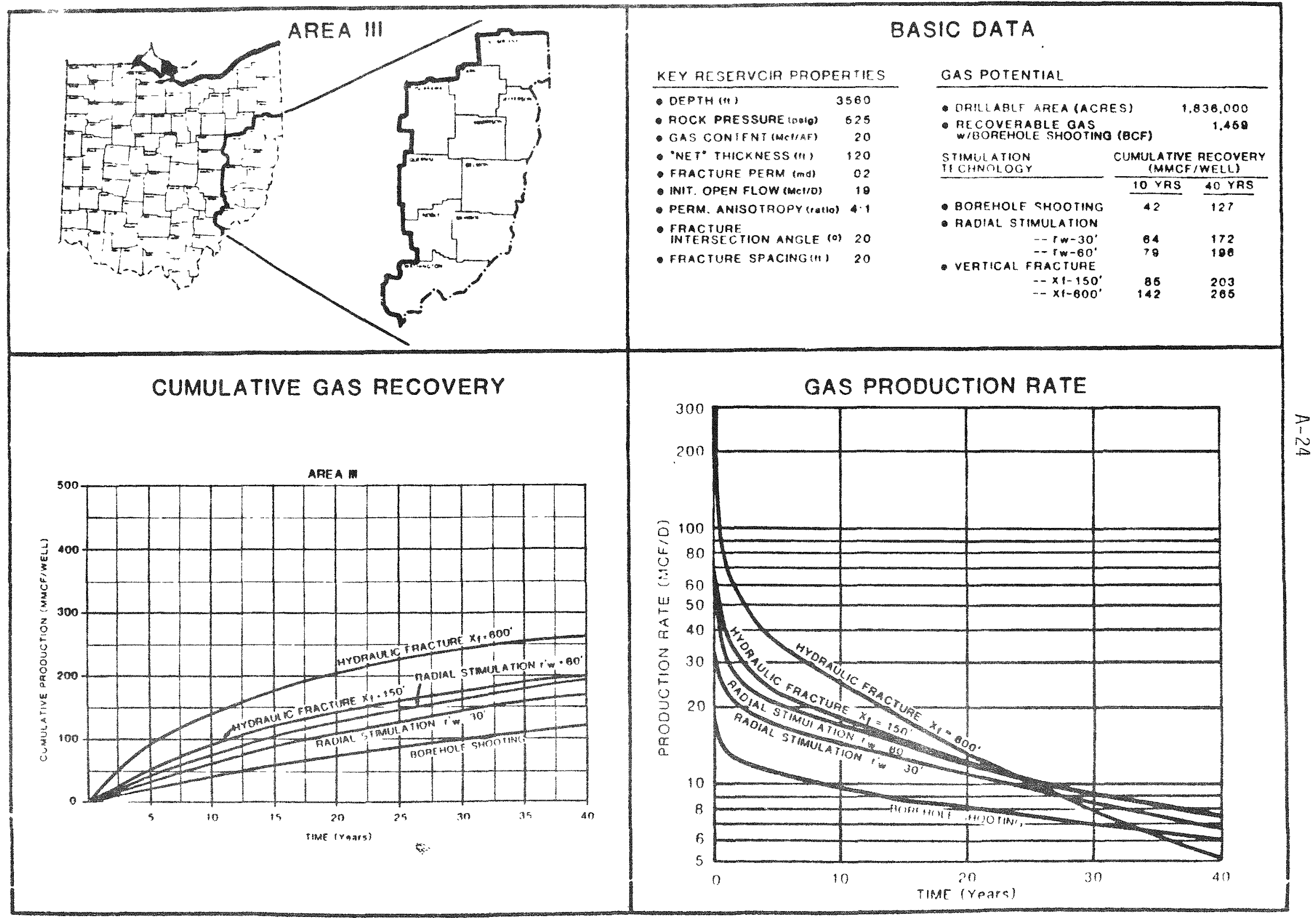


CUMULATIVE GAS RECOVERY BY TYPE OF STIMULATION (MMCf)

(One Well Per 160 Acres)

AREA III

Stimulation Method

\begin{tabular}{|c|c|c|c|c|c|}
\hline Year & $\begin{array}{l}\text { Borehole } \\
\text { Shooting }\end{array}$ & $\begin{array}{c}\text { Small } \\
\text { Radial } \\
\text { Stimulation } \\
r_{W}^{\prime}=30^{\circ}\end{array}$ & $\begin{array}{c}\text { Large } \\
\text { Radial } \\
\text { Stimulation } \\
r^{\prime} w=60^{\circ}\end{array}$ & $\begin{array}{l}\text { Small } \\
\text { Vertical } \\
\text { Fracture } \\
x_{f}=150^{\circ}\end{array}$ & $\begin{array}{l}\text { Large } \\
\text { Vertical } \\
\text { Fracture } \\
x f=600^{\circ}\end{array}$ \\
\hline
\end{tabular}

$\begin{array}{rrrrrr}1 & 5.0 & 8.8 & 11.7 & 13.3 & 29.8 \\ 5 & 22.3 & 36.1 & 45.7 & 49.6 & 92.0 \\ 10 & 41.8 & 64.5 & 79.4 & 84.8 & 142.2 \\ 20 . & 75.4 & 109.9 & 130.7 & 137.5 & 204.6 \\ 40 & 127.2 & 172.1 & 196.0 & 202.8 & 265.3\end{array}$

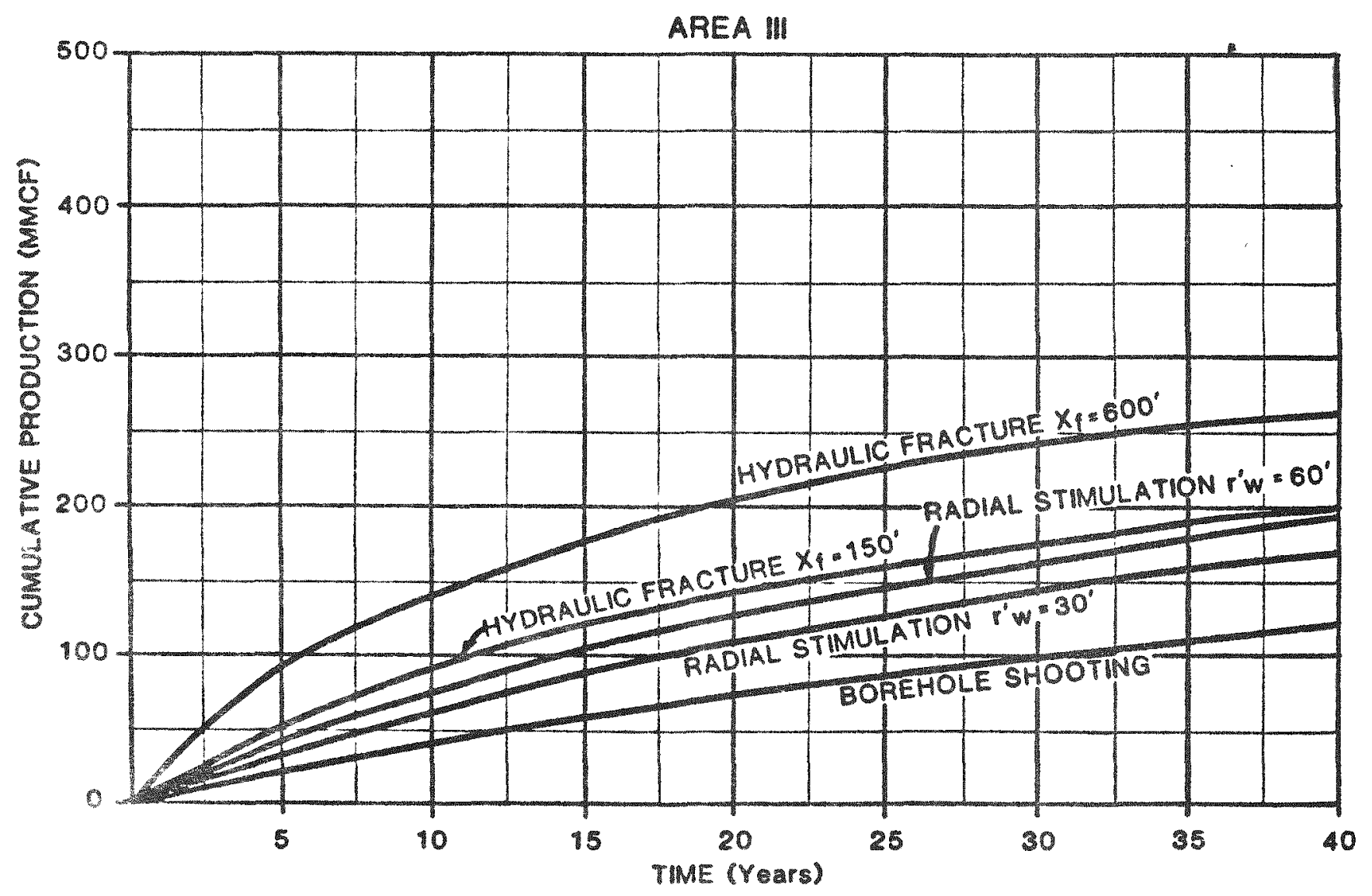




\section{AVERAGE DAILY GAS PRODUCTION BY TYPE OF STIMULATION (MCf/d) AREA III}

Stimulation Method

\begin{tabular}{|c|c|c|c|c|c|}
\hline Year & $\begin{array}{l}\text { Borehole } \\
\text { Shooting }\end{array}$ & $\begin{array}{c}\text { Small } \\
\text { Radial } \\
\text { Stimulation } \\
r^{\prime}{ }^{\prime}=30^{\prime}\end{array}$ & $\begin{array}{c}\text { Large } \\
\text { Radial } \\
\text { Stimulation } \\
r^{\prime}=60^{\circ}\end{array}$ & $\begin{array}{l}\text { Small } \\
\text { Vertical } \\
\text { Fracture } \\
x f=150^{\prime}\end{array}$ & $\begin{array}{l}\text { Large } \\
\text { Vertical } \\
\text { Fracture } \\
x f=600^{\circ}\end{array}$ \\
\hline
\end{tabular}

$\begin{array}{rrrrrr}1 & 13 & 22 & 29 & 31 & 63 \\ 5 & 11 & 17 & 21 & 22 & 35 \\ 10 & 10 & 15 & 17 & 18 & 24 \\ 20 & 8 & 11 & 12 & 12 & 13 \\ 40 & 6 & 7 & 7 & 7 & 5\end{array}$

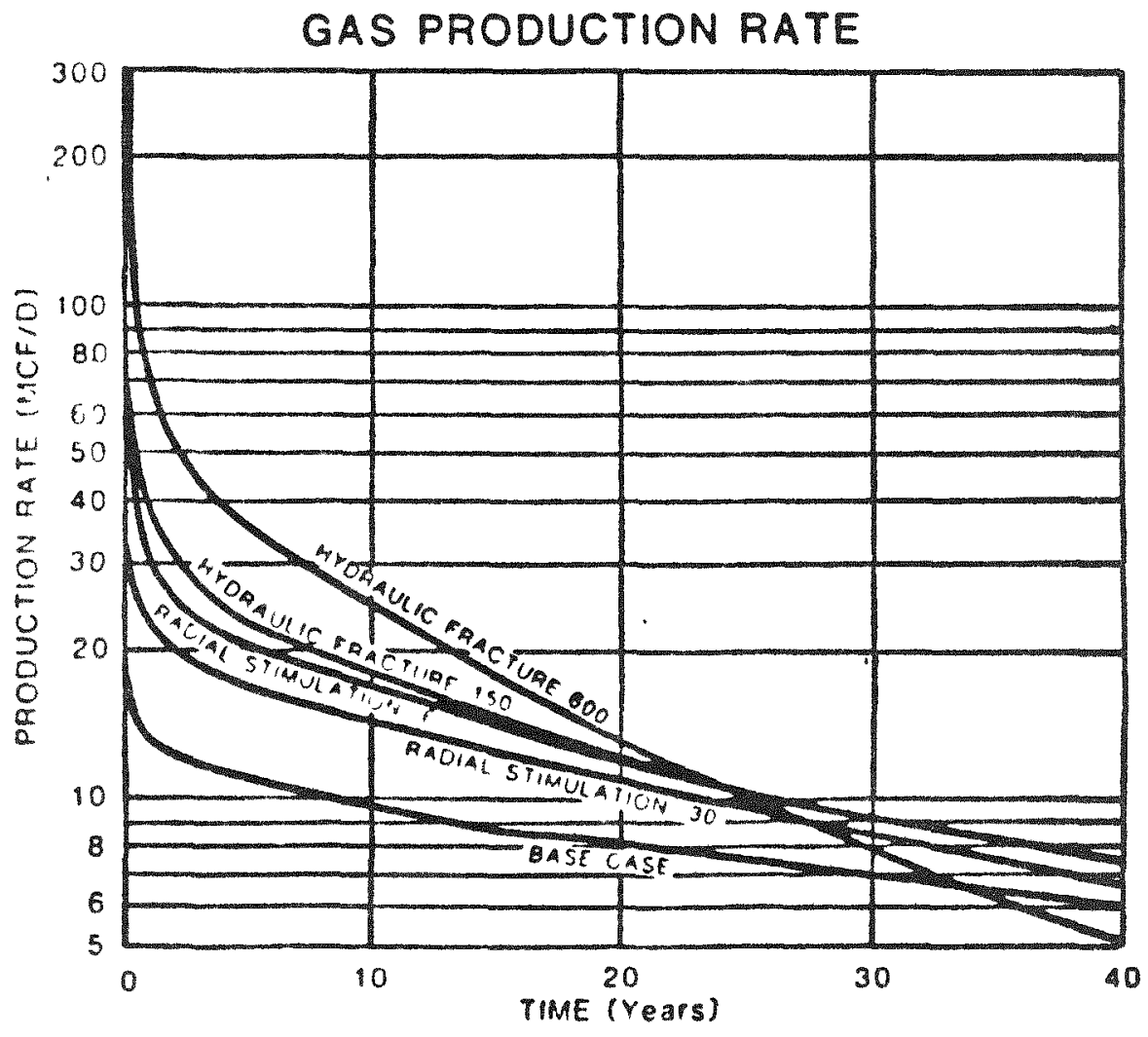


SUMMARY OF OHIO DEVONIAN SHALE GAS POTENTIAL

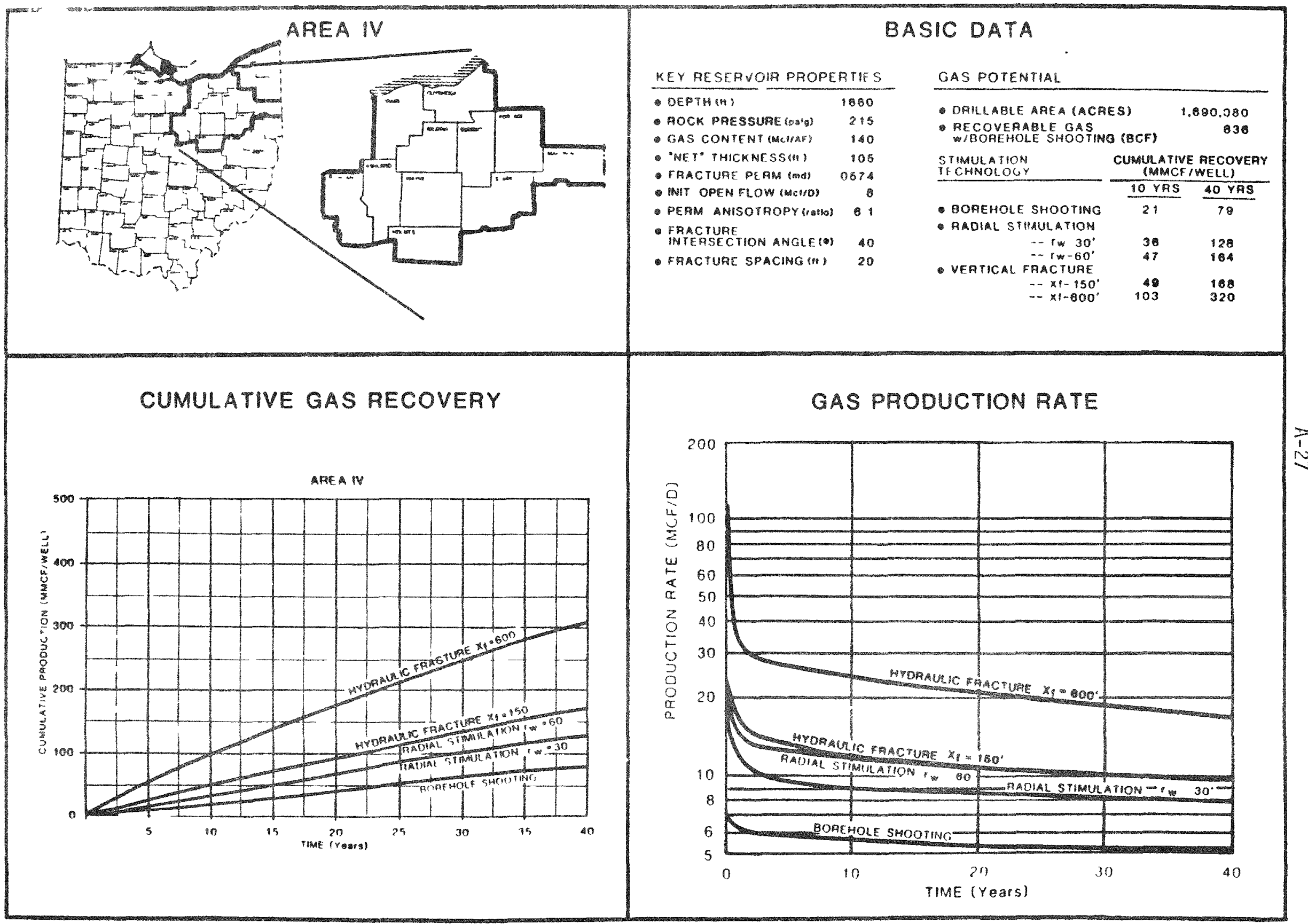


CUPULLATIVE GAS RECOVERY BY TYPE OF STIMULATION (MMCF)

(One Well Per 160 Acres)

AREA IV

Stimulation Method

\begin{tabular}{|c|c|c|c|c|c|}
\hline Year & $\begin{array}{l}\text { Borehole } \\
\text { Shooting }\end{array}$ & $\begin{array}{c}\text { Small } \\
\text { Radial } \\
\text { Stimulation } \\
r_{W}^{\prime}=30^{\circ}\end{array}$ & $\begin{array}{l}\text { Large } \\
\text { Radial } \\
\text { Stimulation } \\
r_{W}^{\prime}=60^{\prime}\end{array}$ & $\begin{array}{l}\text { Small } \\
\text { vertical } \\
\text { Fracture } \\
x_{f}=150^{\circ}\end{array}$ & $\begin{array}{l}\text { Large } \\
\text { Vertical } \\
\text { Fracture } \\
x_{f}=600^{\circ}\end{array}$ \\
\hline
\end{tabular}

$\begin{array}{rrrrrr}1 & 2.2 & 3.8 & 5.1 & 5.4 & 12.2 \\ 5 & 10.7 & 18.4 & 24.4 & 25.6 & 55.8 \\ 10 & 21.1 & 35.6 & 47.0 & 49.0 & 103.4 \\ 20 & 41.1 & 68.1 & 88.7 & 92.0 & 185.5 \\ 40 & 79.1 & 127.9 & 163.9 & 168.4 & 320.0\end{array}$

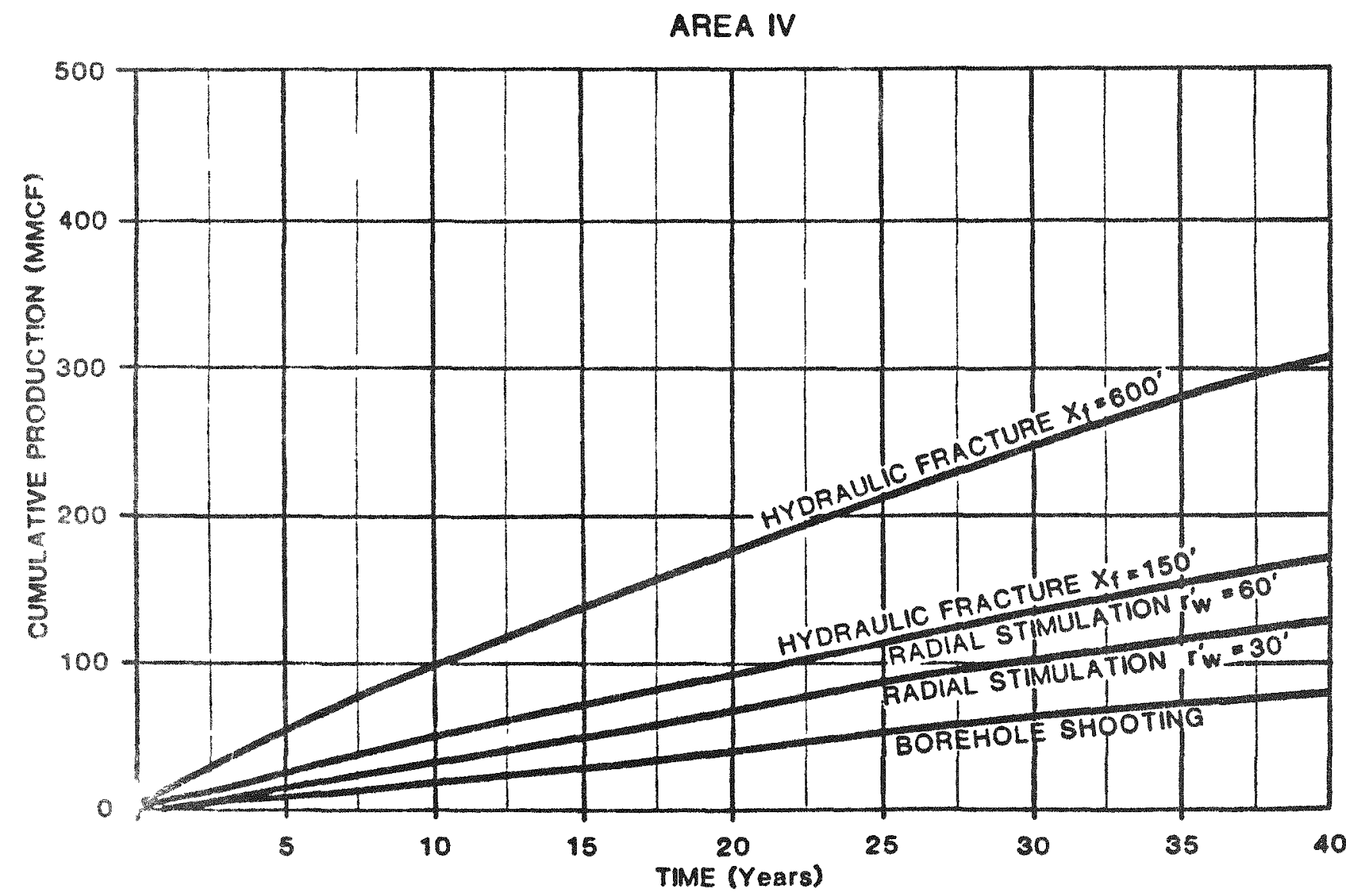


AVERAGE DAILY GAS PRODUCTION BY TYPE OF STIMULATION (MCF/d)

AREA IV

Stimulation Method

\begin{tabular}{cccccc}
\hline Year & $\begin{array}{c}\text { Borehole } \\
\text { Shooting }\end{array}$ & $\begin{array}{c}\text { Small } \\
\text { Radial } \\
\text { Stimulation } \\
r^{\prime} w^{\prime}=30^{\prime}\end{array}$ & $\begin{array}{c}\text { Large } \\
\text { Radial } \\
\text { Stimulation } \\
r^{\prime} w^{\prime}=60^{\circ}\end{array}$ & $\begin{array}{c}\text { Small } \\
\text { Vertical } \\
\text { Fracture } \\
x_{f}=150^{\prime}\end{array}$ & $\begin{array}{c}\text { Large } \\
\text { Vertical } \\
\text { Fracture } \\
x_{f}=600^{\prime}\end{array}$ \\
\hline 1 & 6 & 11 & 14 & 15 & 32 \\
5 & 6 & 10 & 13 & 13 & 28 \\
10 & 6 & 9 & 12 & 12 & 25 \\
20 & 5 & 9 & 11 & 11 & 21 \\
40 & 5 & 8 & 10 & 10 & 17
\end{tabular}

GAS PRODUCTION RATE

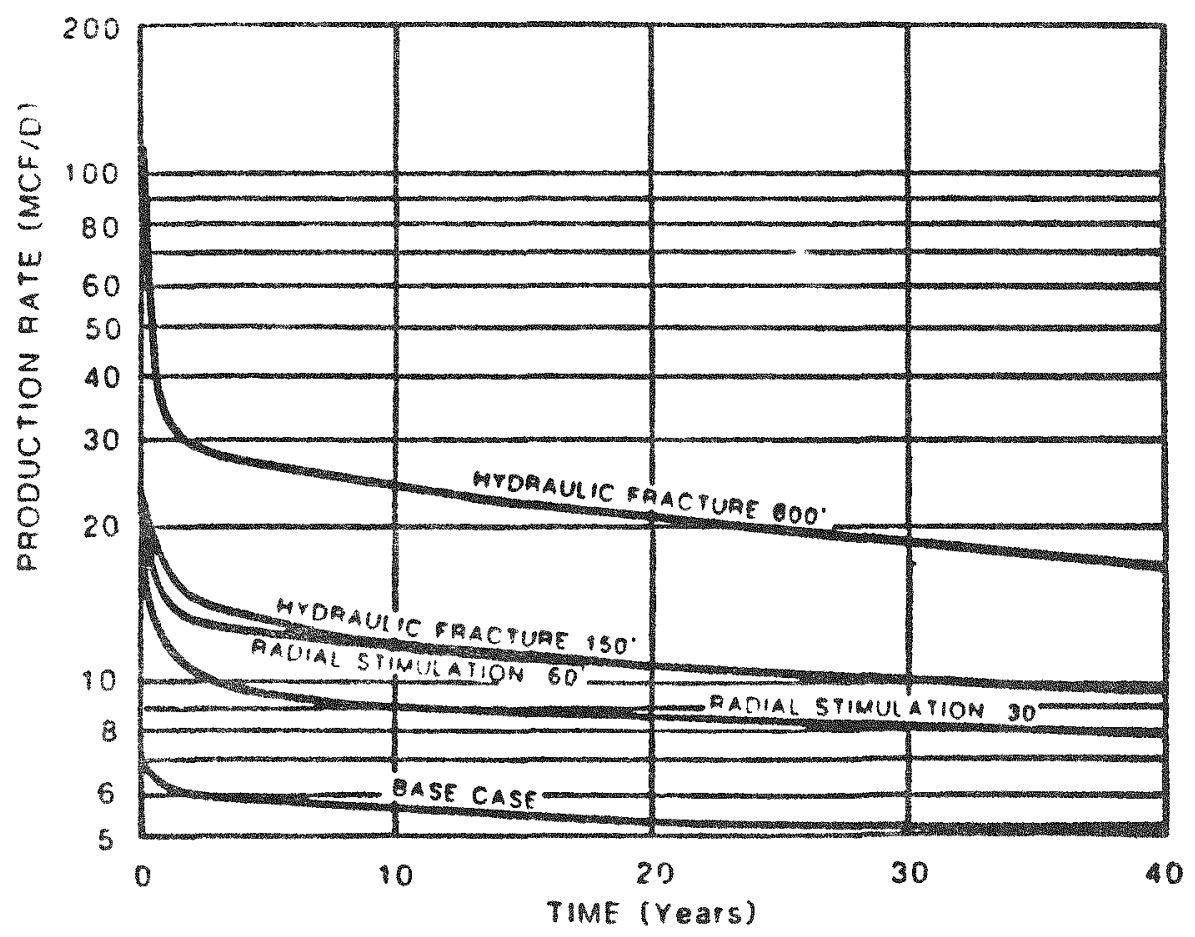




\section{SUMMARY OF OHIO DEVONIAN SHALE GAS POTENTIAL}

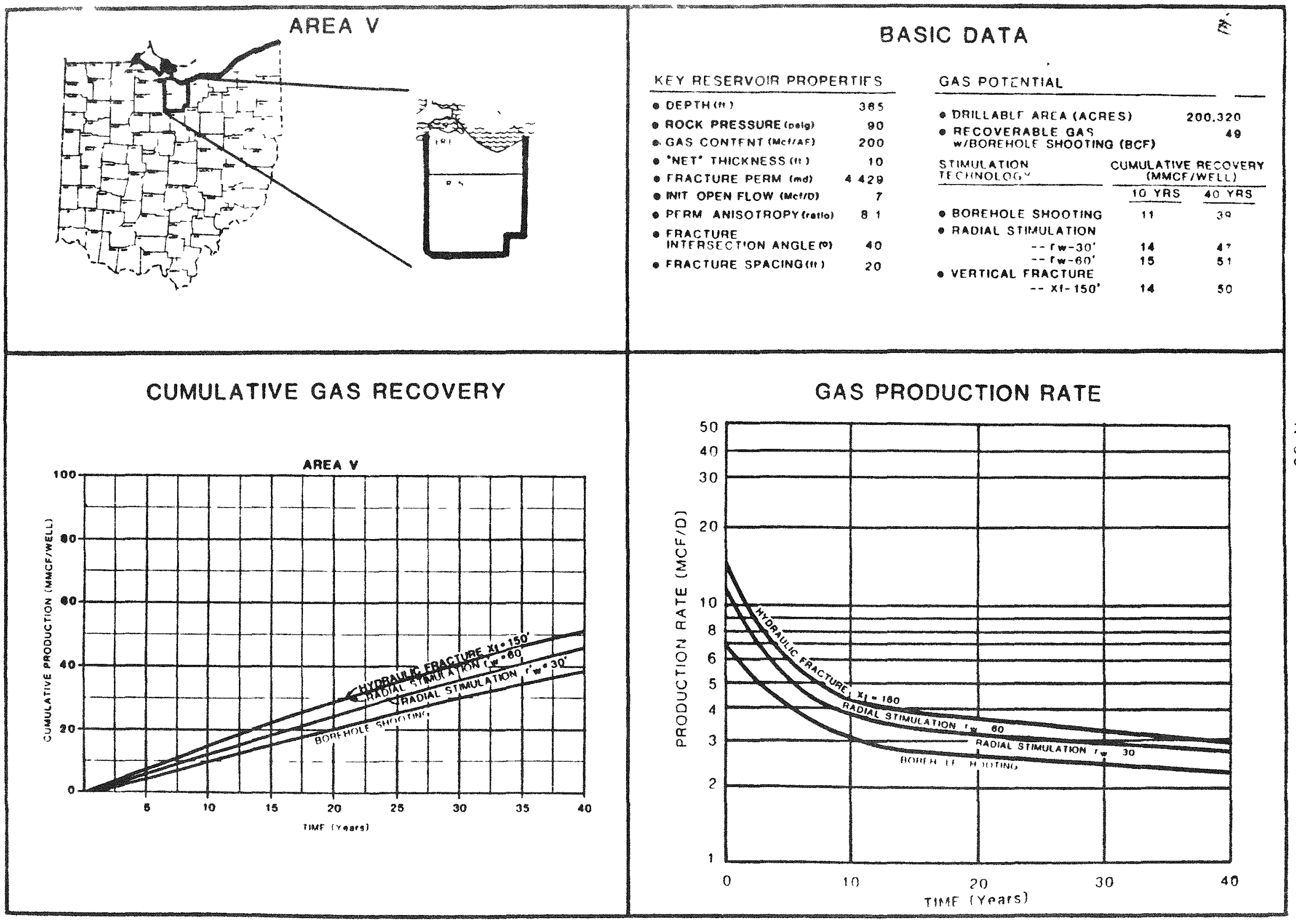


CUMULATIVE GAS RECOVERY BY TYPE OF STIMULATION (MHCF)

(One Well Per 160 Acres)

AREA $V$

\begin{tabular}{rcccc}
\multicolumn{5}{c}{ Stimulation Method } \\
\cline { 2 - 5 } Year & $\begin{array}{c}\text { Borehole } \\
\text { Shooting }\end{array}$ & $\begin{array}{c}\text { Small } \\
\text { Radial } \\
\text { Stimulation } \\
r^{\prime} w^{\prime}=30^{\prime}\end{array}$ & $\begin{array}{c}\text { Large } \\
\text { Radial } \\
r^{\prime} w=60^{\circ}\end{array}$ & $\begin{array}{c}\text { Small } \\
\text { Vertical } \\
\text { Fracture }\end{array}$ \\
\hline 1 & 1.2 & 1.5 & 1.7 & $150^{\prime}$ \\
\hline 5 & 5.6 & 7.0 & 7.7 & 7.6 \\
10 & 10.8 & 13.6 & 14.8 & 14.5 \\
20 & 20.8 & 25.8 & 28.0 & 27.5 \\
40 & 38.8 & 47.2 & 51.0 & 51.0
\end{tabular}

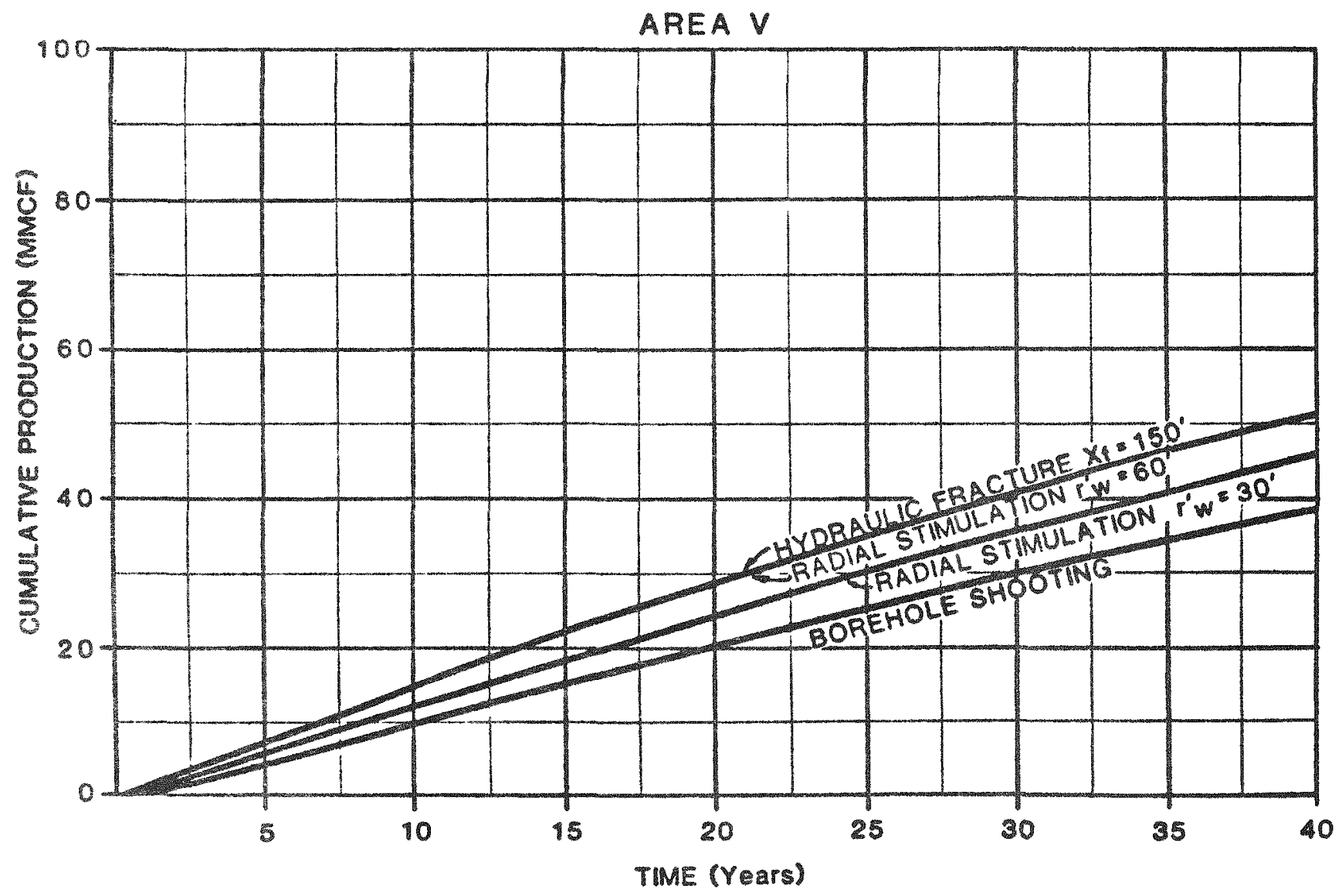




\section{AVERAGE DAILY GAS PRODUCTION BY TYPE OF STIMULATION (MCF/d) \\ AREA $Y$}

Stimulation Method

\begin{tabular}{ccccc}
\cline { 2 - 5 } Year & $\begin{array}{c}\text { Borehole } \\
\text { Shooting }\end{array}$ & $\begin{array}{c}\text { Small } \\
\text { Radial } \\
\text { Stimulation } \\
r^{\prime} w=30^{\prime}\end{array}$ & $\begin{array}{c}\text { Large } \\
\text { Radial } \\
\text { Stimulation } \\
r^{\prime} w^{\prime}=60^{\prime}\end{array}$ & $\begin{array}{c}\text { Small } \\
\text { Vertical } \\
\text { Fracture } \\
\text { Xf }=150^{\prime}\end{array}$ \\
\hline 1 & 3 & 3.8 & 4.0 & 4.1 \\
5 & 3 & 3.7 & 4.0 & 4.0 \\
10 & 3 & 3.5 & 3.8 & 3.8 \\
20 & 2.6 & 3.2 & 3.5 & 3.4 \\
40 & 2.3 & 2.7 & 2.9 & 2.8
\end{tabular}

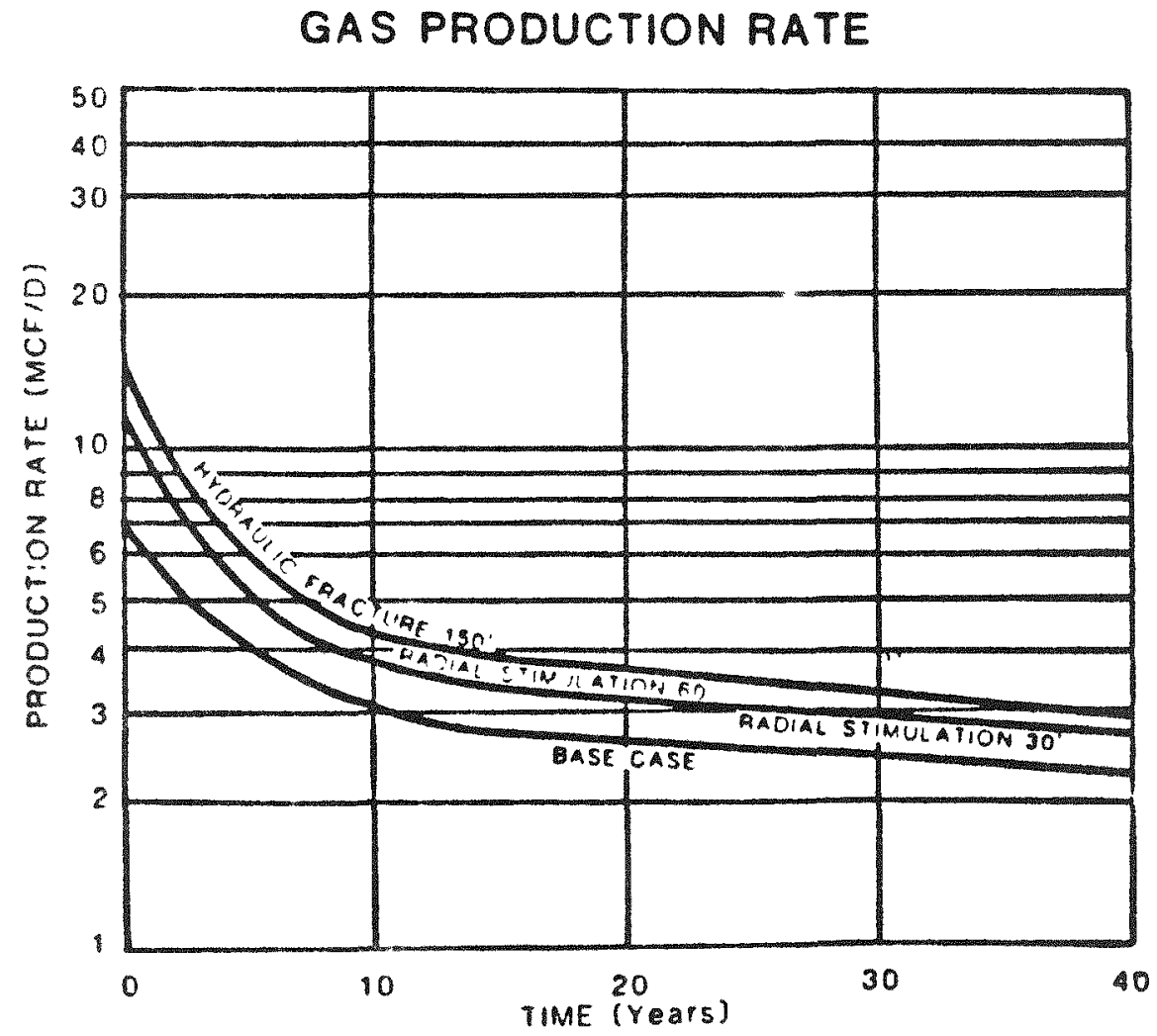


SUMMARY OF OHIO DEVONIAN SHALE GAS POTENTIAL

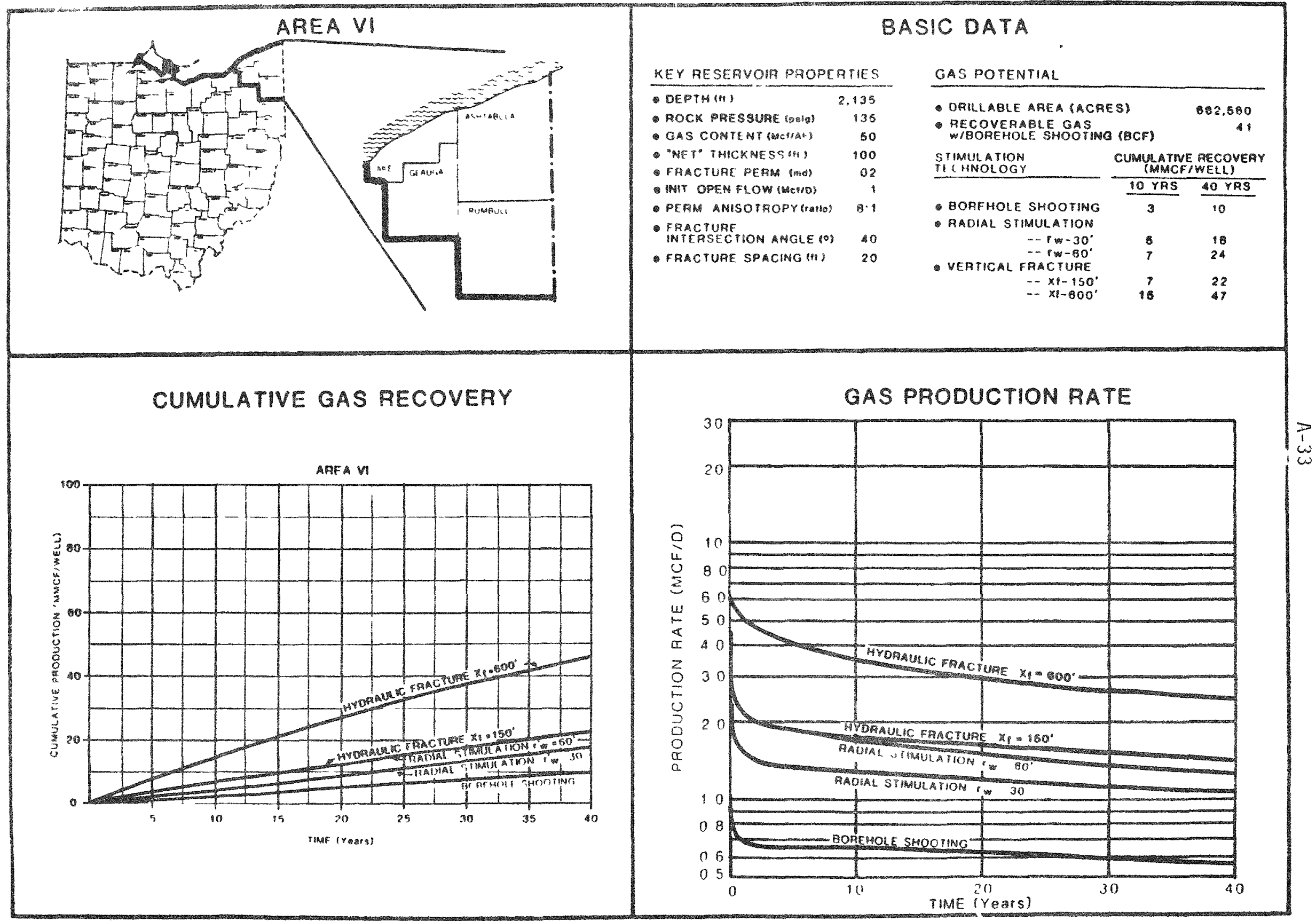


CUMULATIVE GAS RECOVERY BY TYPE OF STIMULATION (MMCF)

(One Well Per 160 Acres)

AREA VI

\begin{tabular}{cccccc}
\multicolumn{5}{c}{ Stimulation Method } \\
\cline { 2 - 6 } Year & $\begin{array}{c}\text { Borehole } \\
\text { Shooting }\end{array}$ & $\begin{array}{c}\text { Small } \\
\text { Radial } \\
\text { Stimulation } \\
r^{\prime} w^{\prime}=30^{\prime}\end{array}$ & $\begin{array}{c}\text { Large } \\
\text { Radial } \\
\text { Stimulation } \\
r^{\prime} w^{\prime}=60^{\circ}\end{array}$ & $\begin{array}{c}\text { Small } \\
\text { Vertical } \\
\text { Fracture } \\
x_{f}=150^{\prime}\end{array}$ & $\begin{array}{c}\text { Large } \\
\text { Vertical } \\
\text { Fracture } \\
x_{f}=600^{\prime}\end{array}$ \\
\hline 1 & 0.3 & 0.5 & 0.8 & 0.7 & 1.9 \\
5 & 1.3 & 2.6 & 3.6 & 3.5 & 8.4 \\
10 & 2.6 & 5.0 & 6.9 & 6.6 & 15.4 \\
20 & 5.1 & 9.5 & 12.9 & 12.3 & 27.4 \\
40 & 9.8 & 17.7 & 23.6 & 22.4 & 47.0
\end{tabular}

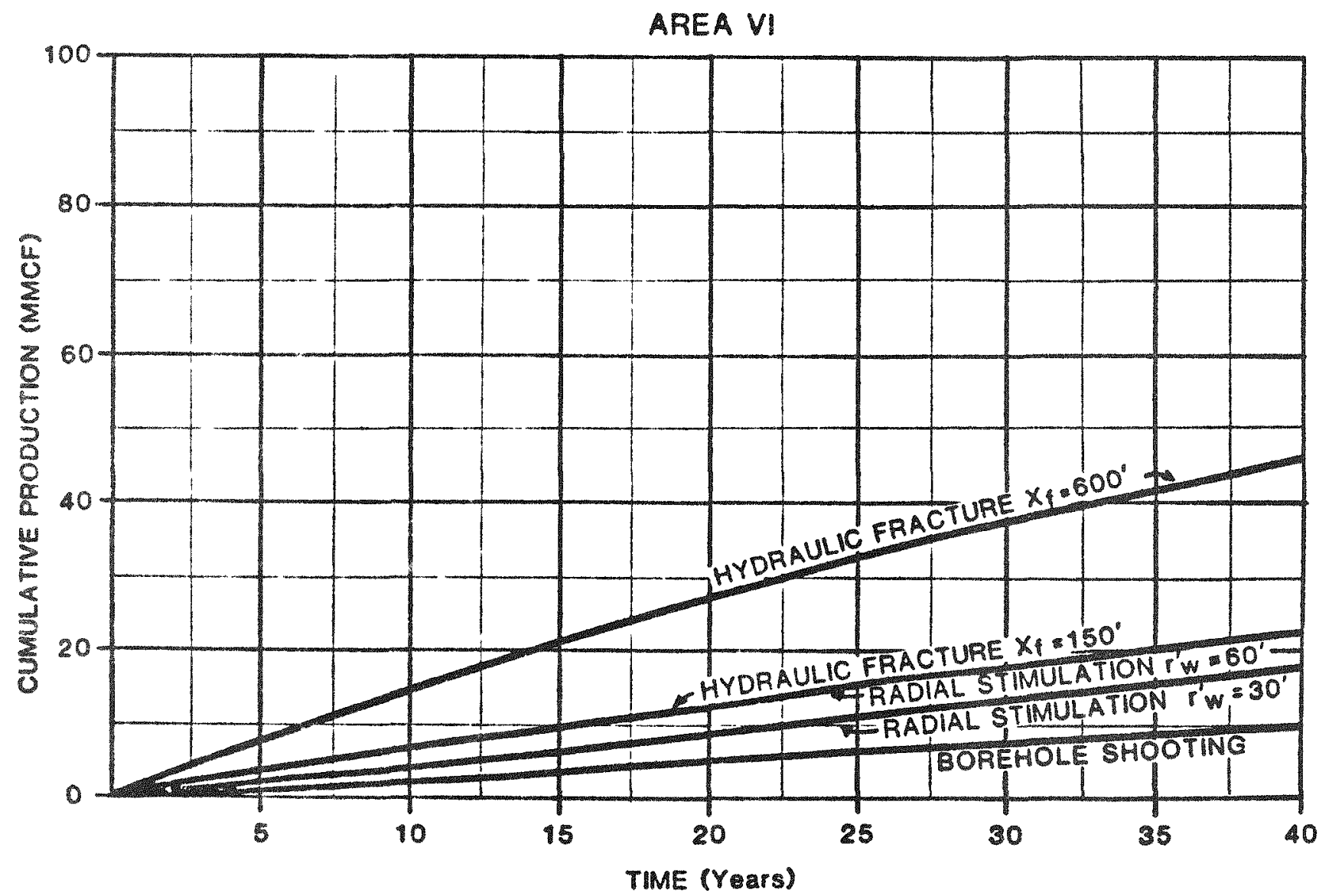


AYERAGE DAILY GAS PRODUCTION BY TYPE OF STIMULATION (MCf/d) AREA VI

Stimulation Method

\begin{tabular}{|c|c|c|c|c|c|}
\hline Year & $\begin{array}{l}\text { Borehole } \\
\text { Shooting }\end{array}$ & $\begin{array}{c}\text { Small } \\
\text { Radial } \\
\text { Stimulation }\end{array}$ & $\begin{array}{c}\text { Large } \\
\text { Radial } \\
\text { Stimulation }\end{array}$ & $\begin{array}{l}\text { Small } \\
\text { Vertical } \\
\text { Fracture }\end{array}$ & $\begin{array}{l}\text { Large } \\
\text { Vertical } \\
\text { Fracture }\end{array}$ \\
\hline & & $r_{w}^{\prime}=30^{\circ}$ & $r_{w}^{\prime}=60^{\circ}$ & $x f=150^{\circ}$ & $x_{f}=600^{\circ}$ \\
\hline
\end{tabular}

$\begin{array}{rrrrrr}1 & 0.7 & 1.5 & 2.0 & 2.0 & 4.9 \\ 5 & 0.7 & 1.4 & 1.9 & 1.8 & 4.2 \\ 10 & 0.7 & 1.3 & 1.7 & 1.7 & 3.7 \\ 20 & 0.7 & 1.2 & 1.6 & 1.5 & 3.0 \\ 40 & 0.6 & 1.1 & 1.4 & 1.3 & 2.5\end{array}$

GAS PRODUCTION RATE

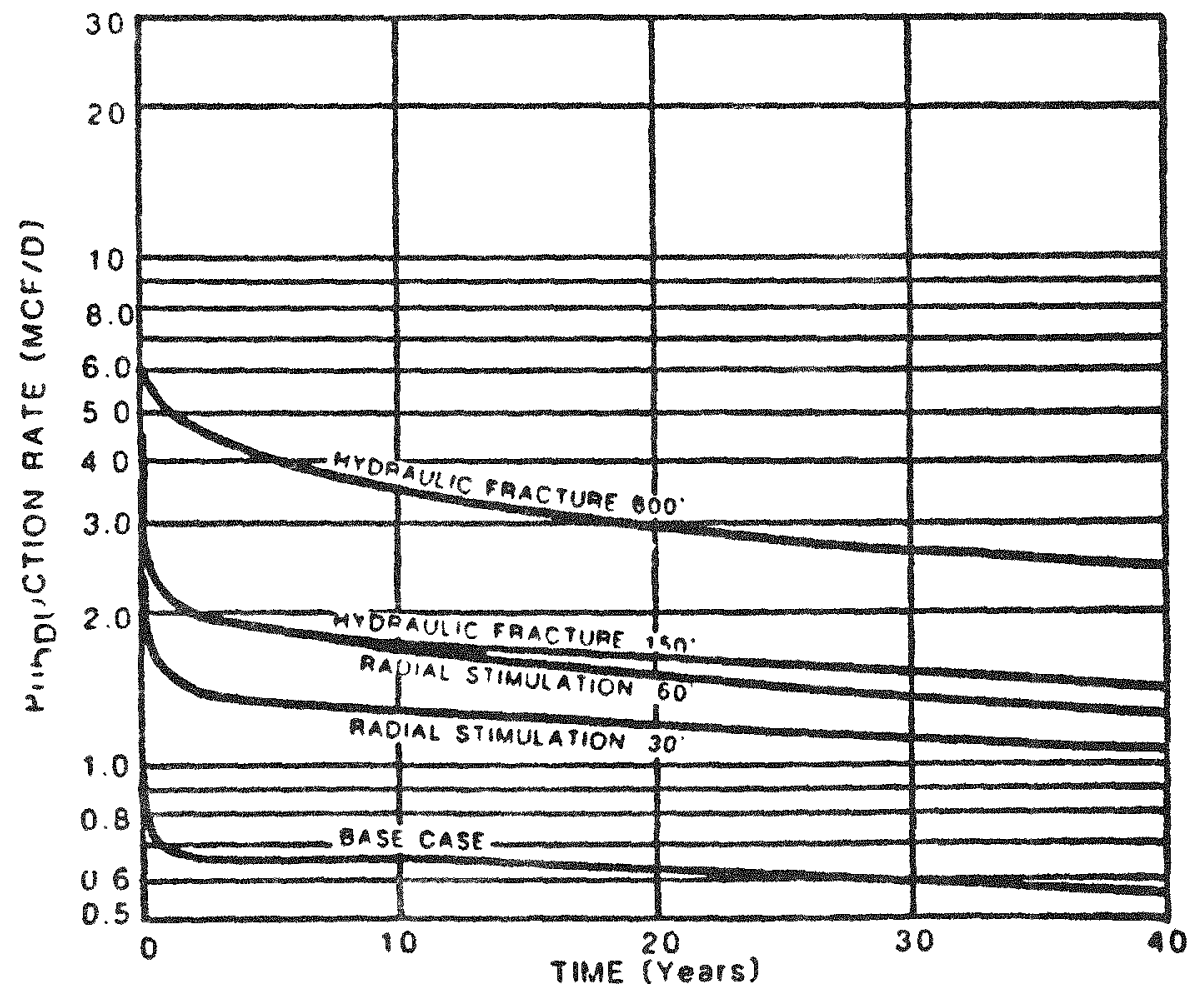

